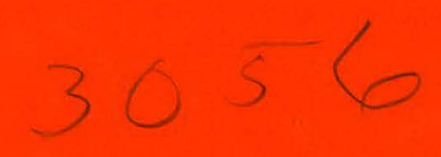

\title{
Standards, Building Codes, and Certification Programs for Solar Technology Applications
}

Julia D. Riley Robert Odland Helen Barker
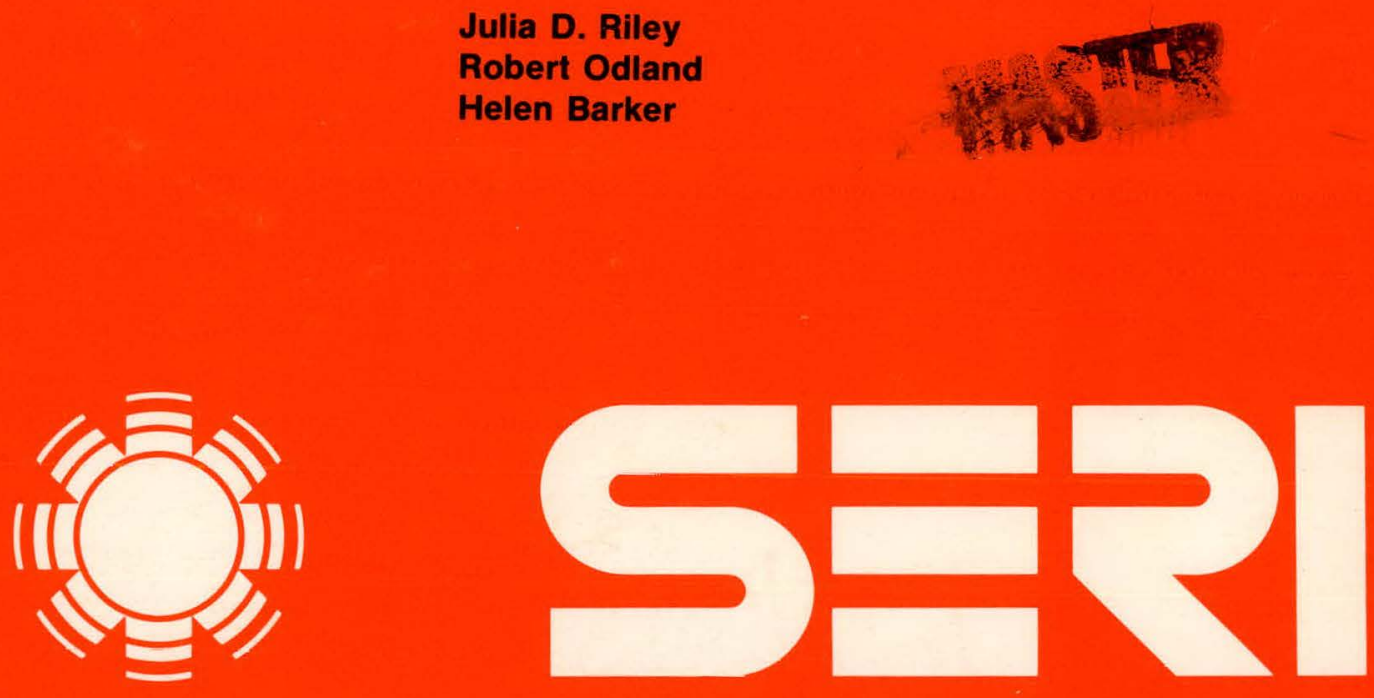

Solar Energy Research Institute A Division of Midwest Research Institute

1536 Cole Boulevard

Golden, Colorado 80401

Operated for the U.S. Department of Energy under Contract No. EG-77-C-01-4042

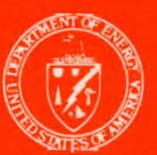




\section{DISCLAIMER}

This report was prepared as an account of work sponsored by an agency of the United States Government. Neither the United States Government nor any agency Thereof, nor any of their employees, makes any warranty, express or implied, or assumes any legal liability or responsibility for the accuracy, completeness, or usefulness of any information, apparatus, product, or process disclosed, or represents that its use would not infringe privately owned rights. Reference herein to any specific commercial product, process, or service by trade name, trademark, manufacturer, or otherwise does not necessarily constitute or imply its endorsement, recommendation, or favoring by the United States Government or any agency thereof. The views and opinions of authors expressed herein do not necessarily state or reflect those of the United States Government or any agency thereof. 


\section{DISCLAIMER}

Portions of this document may be illegible in electronic image products. Images are produced from the best available original document. 
Frinted in the United States of America

Available from:

National Technical Information Service

U.S. Department of Commerce

5285 Port Royal Road

Springfield, VA 22161

Frice:

Microfiche $\$ 3.00$

Printed Copy $\$ 7.25$

\section{NOTICE}

This report was prepared as an account of work sponsored by the United States Government. Neither the United States nor the United States Department of Energy, nor any of their employees, nor any of their contractors, subcontractors, or their employees, makes any warranty, express or implied, or assumes any legal liability or responsibility for the accuracy, completeness or usefulness of any information, apparatus, product or process disclosed, or represents that its use would not infringe privately owned rights. 
SERI /TR-53-095

UC CATEGORY: UC-59,59 A,59 B,59 C, 60

$61,62,62 A, 63$

STANDARDS, BUILDING CODES, AND CERTIFICATION PROGRAMS FOR

SOLAR TECHNOLOGY APPLICATIONS

JULIA D. RILEY

ROBERT ODLAND

HELEN BARKER

JULY 1979

Notice

This report was prepared as an account of work sponsored by the United States Government. Neither the United States no: the United States Department of Energy, not any of their employees, nor any of their contractors, subcontractors, or their employees, makes any warranty, express or implied, or assumes any legal liability or responsibility for the accuracy, completeness or use futness of any information, apparatus, product or process disclosed, or represents that its use would iot infringe privately owned rights.

PREPARED UNDER TASK NO. 5311 AND 6107.02

\section{Solar Energy Research Institute}

1536 Cole Boulevard

Golden, Colorado 80401

A Division of Midwest Research Institute

Prepared for the

U.S. Department of Energy

Contract No. EG.77.C.01.4042 
THIS PAGE

WAS INTENTIONALLY

LEFT BLANK 


\section{FOREWORD}

This report was prepared in compliance with Contract No. EG-77-C-01-4042 for the U.S. Department of Energy (DOE). The report was prepared as part of two SERI tasks (Task 5311 in the Institutional and Environmental Assessment Branch and Task 6107.02 in the Commercial Readiness Branch) and in cooperation with DOE, Conservation and Solar Applications. David Pellish provided assistance and guidance. Section 4.0 is based in part upon work done by the PRC Energy Analysis Company for DOE; the original authors of the PRC work were Patricia Mataset and Grayson Heffner.

Project coordinator and Task 5311 leader was Robert Odland. Task 6107.02 leader was Julia D. Riley. Principal authors were Julia D. Riley, Helen Barker, and Robert Odland. Michael Green, Jill Gross, and Charlotte Schwab, summer legal interns, wrote portions of the report dealing with state and local activities and with biomass. Cindy Andersen compiled the bibliography.

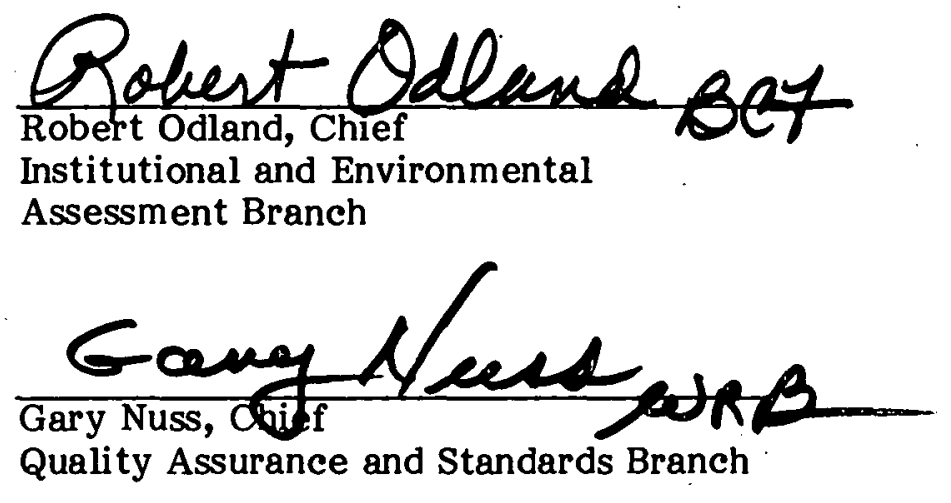

Approved for:

SOLAR ENERGY RESEARCH INSTITUTE

K. Simmons, Assistant Director

Melvin K. Simmons
Analysis Division

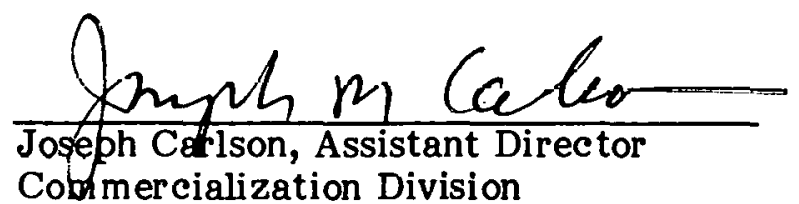




\section{THIS PAGE}

\section{WAS INTENTIONALLY \\ LEFT BLANK}




\section{TABLE OF CONTENTS}

Page

1.0 Introduction $\ldots \ldots \ldots \ldots \ldots \ldots \ldots \ldots \ldots \ldots \ldots \ldots \ldots \ldots \ldots \ldots \ldots \ldots \ldots \ldots \ldots \ldots$

2.0 Standards Development Process $\ldots \ldots \ldots \ldots \ldots \ldots \ldots \ldots \ldots \ldots \ldots \ldots \ldots \ldots \ldots$

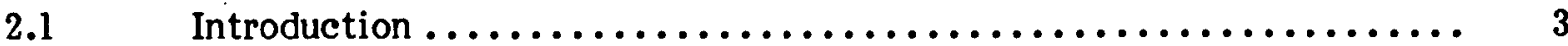

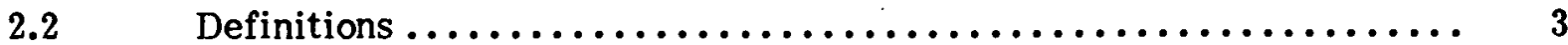

2.3 Process of Standards Development.................... 4

2.3.1 Voluntary Consensus Standards ................. 4

2.3.2 Participants in Solar Standards Writing ............... 7

3.0 Building Codes Development Process........................ 11

$3.1 \quad$ Introduction $\ldots \ldots \ldots \ldots \ldots \ldots \ldots \ldots \ldots \ldots \ldots \ldots \ldots \ldots \ldots \ldots \ldots \ldots \ldots$

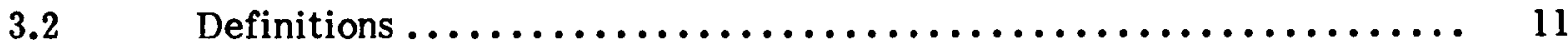

3.3 Process of Building Codes Development ................... 12

4.0 Certification Program Development Process ..................... '13

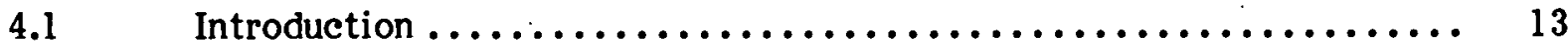

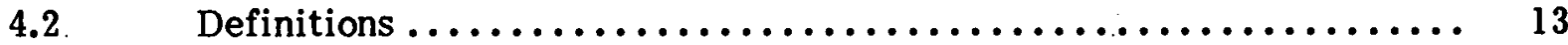

4.2.1 American National Standards Institute .............. 13

4.2.2 Underwriters Laboratories...................... 14

4.2.3 Quality Control Programs ..................... 14

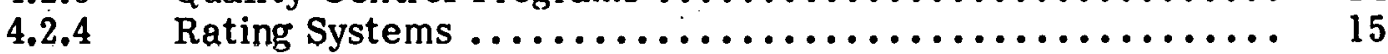

4.3 Process of Certification Program Development.............. 15

5.0 Commercialization and Standards $\ldots \ldots \ldots \ldots \ldots \ldots \ldots \ldots \ldots \ldots \ldots \ldots \ldots \ldots$

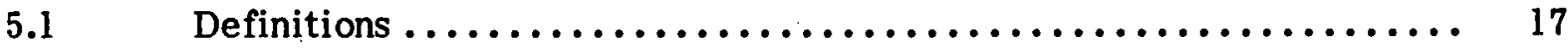

5.2 Standards Issues in the Commercialization Process............ 23

6.0 Federal Policies in Standards, Building Codes, and

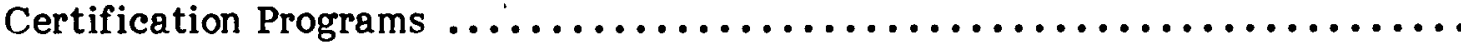

6.1 Government Support for the Standards Development

Process .....................................

6.1.1 Direct Financial Support: Grants, Sustaining Memberships, and Contracts ................... 25

6.1.2 Administrative Support: Travel Cost, Hosting of Meetings, and Secretarial Functions ............... 26

6.1.3 Technical Support: Cooperative Testing Standards Fvaluation and Participation of Agency Personnel on Standards Committees 
6.1.4 Joint Planning with the Voluntary Standards Community to Ensure Coordination in Resolving

6.1 .5 Standardization Problems ..................... 26

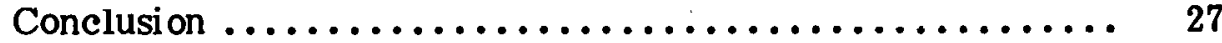

6.2 Government Support for the Building Code Process $\ldots \ldots \ldots \ldots \ldots \ldots \ldots$

6.2.1 Developments in the Model Code Associations........... 28

6.2.2 DOE's Contract for a Model Solar Document and for Training Programs ..................... 28

6.3 Government Support for Certification Policies $\ldots \ldots \ldots \ldots \ldots \ldots \ldots \ldots \ldots .29$

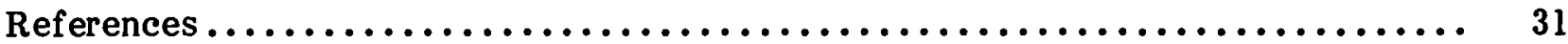

Bibliography $\ldots \ldots \ldots \ldots \ldots \ldots \ldots \ldots \ldots \ldots \ldots \ldots \ldots \ldots \ldots \ldots \ldots \ldots \ldots \ldots \ldots \ldots \ldots \ldots$

Appendix A. State and Local Issues $\ldots \ldots \ldots \ldots \ldots \ldots \ldots \ldots \ldots \ldots \ldots \ldots \ldots \ldots \ldots$

Appendix B. Solar Heating and Cooling Systems $\ldots \ldots \ldots \ldots \ldots \ldots \ldots \ldots \ldots \ldots \ldots \ldots$.

Appendix C. Agricultural and Industrial Process Heat Systems ............. 77

Appendix D. Biomass Energy Conversion Systems $\ldots \ldots \ldots \ldots \ldots \ldots \ldots \ldots \ldots \ldots \ldots$

Appendix E. Wind Energy Conversion Systems $\ldots \ldots \ldots \ldots \ldots \ldots \ldots \ldots \ldots \ldots \ldots \ldots \ldots$

Appendix F. Photovoltaics................................ 101

Appendix G. Solar Thermal Electric Power Systems ................... 109

Appendix H. Ocean Thermal Energy Conversion.................... 117

Appendix 1. UMB Clrcular uil Federal Interaction with the

Voluntary Consensus System ......................... 123

Appendix J. Extract from DOE/CABO Contract EM-78-COT-4281

"Development of a Model Document for Code Officials on Solar Heating and Cooling of Buildings" Executed Sept. 1978: Statement of Work

\section{LIST OF TABLES}

5-1 Standards Development Activities in the Commercialization Process

\section{LIST OF PIGURES}

5-1 Description of Standards Events in Commercialization 


\section{SECTION 1.0}

\section{INTRODUCTION}

Standards, building codes, and certification programs raise significant issues in the commercialization of solar technologies. Much controversy exists over the applicability of certain types of standards, their timing, and the institutions involved. Likewise, building codes, of ten cited as barriers to solar applications, present questions of content, ease of amendment, and intergovernmental relations. Certification programs, which generally are quality assurance tools in other technologies, are emerging at a rapid rate for solar applications. Underlying these activities is federal government acceleration of the processes to encourage widespread commercialization.

This report examines the development processes in the private sector as well as government activity. It is directed to three audiences:

- federal officials in solar programs;

- participants in the development processes; and

- state and local officials.

General emphasis is on federal policies, which rely on the traditional institutional framework-the voluntary consensus system-for the development of standards, building codes, and certification programs.

This report is a cooperative effort between the Solar Energy Research Institute (SERI) and Department of Energy (DOE). Numerous representatives of the standards-writing community from both the public and private sectors were consulted during its preparation.

Sections 1.0 through 4.0 describe the project approach and the development processes. These chapters provide the framework for discussion of commercialization in Section $\mathbf{5 . 0}$ and policies in Section 6.0. Appendix A reviews selected state and local activities. Appendices $B$ through $\mathrm{H}$ discuss standards, building codes, and certification for several solar technologies. Appendix I contains a reproduction of an OMB circular on government employee participation in the voluntary consensus system. Appendix $J$ excerpts an executed contract to develop a model building document for solar heating and cooling applications. 


\section{SEPI}




\section{SECTION 2.0}

\section{STANDARDS DEVELOPMENT PROCESS}

\subsection{INTRODUCTION}

Standards affect all segments of the technology community through effects on product costs, product demand, and the competitive nature of an industry. Effects on product costs can be brought about through the reduction of unnecessary grades or product lines, and labor costs can be reduced through interchangeability of parts. Properly written standards can allow a new product to be interchangeable with one from an existing technology. Poorly written standards can make this design departure difficult. Through minimum quality standards, consumer confidence in a product may increase. Markets can widen if the effects of brand names are mitigated, or if products are interchangeable. Some danger may ar ise from manufacturers' coming together to write standards, if they do so without due process and exclude other segments of a standards community [1]. Standards are the keystones of building code provisions and certification programs. This section explains the process by which they are developed, as well as some of the issues involved.

Standards for solar technology applications have gained importance during the past year, mainly because of issues relating to standards in general: consumer protection and participation in the standards-setting process, state and federal tax incentives, and the role of standards in creating incentives or in inhibiting innovation. These issues pertain to the use of standards. To understand the issues involved in standards development, it is useful to understand both the process itself and federal policies concerning standards for solar technology applications.

\subsection{DEFINITIONS}

Standards are the agreed-upon language among producers, users, and others interested in the functions, properties, and characteristics of materials, products, systems, and services. Five kinds of standards are defined by the American Society for Testing and Materials (ASTM)-producer of the greatest volume of voluntary consensus standards:

- Standard DEFINITIONS are the basis for a common language for a given area of knowledge [2].

- Standard CLASSIFICATIONS define systematic arrangement or division into groups based on similar characteristics such as origin, composition, properties, or use [3] .

- Standard SPECIFICATIONS are precise statements of a set of requirements to be satisfied by a material, product, or system, indicating wherever appropriate the procedure to determine whether the requirements are satisfied. As far as practicable, the requirements should be expressed numerically in appropriate units with their limits [3].

- Standard METHODS OF TEST cover sampling and subśsuent testing procedures used in determining properties, composition, or performance specified. A test method does not include limits for the properties, composition, or performance [3]. 
- A standard RECOMMENDED PRACTICE is a procedure, guide, or service that may be auxiliary to a test method or specification. Examples include selection, preparation, application, inspection, necessary precautions for use or disposal, installation, maintenance, and operation of testing apparatus [3] .

Many other consensus standards organizations have also established their own classifications or definitions of standards. The first standards were common units of measure which have evolved from simple references to common objects (stone weights, for example) to today's carefully calibrated weights and measures. Standards development played no small part in the achievements of the Industrial Revolution, from the origin of interchangeable parts to the assembly line to the highly specialized division of labor that characterizes work today [2].

\subsection{PROCESS OF STANDARDS DEVELOPMENT}

Methods of standards development vary according to the needs of the users. The United States is one of few nations without a federal body whose purpose is to develop standards. Generally, standards development is an amalgamation of interests in both the private and public sectors. The degree of consensus in development is a direct function of the need for and the end use of a standard.

- A COMPANY STANDARD is developed by a business for internal use, usually covering proprietary information. The Coca-Cola recipe is a company standard [2].

- INDUSTRY STANDARDS are commonly developed and used by a trade association or a professional society. For example, the practices of floor tile installation are passed on via experience and training [2] :

- Federal, state, and local governments develop and use three kinds of GOVERNMENT STANDARDS:

Etandard weights and measures are the pluvinue of the Nutlonal Bureau of Standards (NBS).

- Governments are huge consumers of goods and services and have developed purchasing specifications that must be met by suppliers.

- Governments have an increasingly large role in the development of policy applications in housing, urban development, energy, and the envirnnment. The federal government has developed, promulgated, and enforced such standards as the Federal Housing Administration (FHA) Minimum Property Standards (MPS) [2].

- VOLUNTARY CONSENSUS STANDARDS are developed by private, nonprofit organizations and are the most widely accepted and used standards. The discussion which follows focuses on the voluntary consensus standards system as it relates to standards development for solar technology applications.

\subsubsection{Voluntary Consensus Standards}

To have credence, a voluntary consensus standard must be developed by an organization having the appropriate authority and responsibility. Professional societies, trade associations, and organizations with a specific state-given charter to write standards include standards-development procedures as an integral part of their bylaws. Maintain- 
ing a balance of interests among producers, users, consumers, academicians, regulatory agencies, and other interested parties is vital to the process. A chief feature of the system by which standards are developed is protection of the right of dissent; all who have an interest in a standard should have an opportunity to have a voice in its development.

Although each technical society has its own procedures for developing standards, all methods involve a balance of interests and periodic review. The procedural credibility of an organization is as important as its technical credibility. Failure to adhere to any procedural or legal consideration may negate technical credibility. Restraint of trade and antitrust considerations are frequent concerns in the standards-setting process. The Federal Trade Commission (FTC) maintains a careful watch over the system, and occasionally cases are brought to court to test the process. There is no legislation protecting the voluntary consensus system from antitrust actions [2].

The oversight function for the development of voluntary consensus standards is maintained by the American National Standards Institute (ANSI). ANSIs membership is comprised of over 400 organizations, some of which write standards, all of which participate in the process. Each organization that writes standards under ANSI must have its procedures approved. Upon approval and acceptance by ANSI, the standards are promulgated as American National Standards. To obtain approval, the organization must have a sound procedural process for standards development.

ANSI has four functions:

- act as the national coordinator for standardization in the United States;

- act as the independent organization for approval of standards as American National Standards;

- serve as a clearinghouse for information on American National. Standards and on international standards; and

- represent the standards position of the United States in international non-treaty organizations such as the International Organization for Standardization (IOS) and the International Electrotechnical Commission (IEC) [2].

ANSTs Solar Standards Steering Committee (SSSC)-oversees solar standard development. At this time, its scope is limited to standards for solar heating and cooling of buildings (SHACOB), solar hot water, and photovoltaics. The SSSC does not write standards, but rather coordinates standards development through its member organizations by identifying needs and formulating specific tasks for member organizations. Those tasks are assigned and an overview of their activities is maintained to avoid duplication of effort and conflicting standards [4].

In June 1978, the SSSC approved the Plan for Development and Implementation of Standards for Solar Heating and Cooling Applications as written by the National Bureau of Standards (NBS). The plan identifies the status of standards, the organizations responsible for development, needs, and priorities, and time frames for completition. This document will be the management tool for SSSC supervision of standards development for solar heating and cooling. Similar management tools have yet to be developed for other solar technology applications such as wind or solar thermal.

Membership in the SSSC is comprised of institutions within the solar standards community. The following is a partial list of members. 
- Air Conditioning and Refrigeration Institute (ARI)

- American Gas Association (AGA)

- American Institute of Architects (AIA)

- American Society of Heating, Refrigerating, and Air Conditioning Engineers (ASHRAE)

- American Society of Mechanical Engineers (ASME)

- American Society for Testing and Materials (ASTM)

- Architectural Aluminum Manufacturers Association (AAMA)

- Department of Energy (DOE)

- General Services Administration (GSA)

- Institute of Electrical and Electronics Engineers (IEEE)

- International Association of Plumbing \& Mechanical Officials (IAPMO)

- Manufactured Housing Institute (MHI)

- National Contractor Association of America (NCAA)

- National Aeronauties and Space Administration (NASA)

- National Association of Home Builders (NAHB)

- National Bureau of Standards (NBS)

- National Conference of States on Building Codes and Standards (NCSBCS)

- Sheet Metal and Air Conditioning Contractors National Association (SMACNA)

- Solar Energy Industries Association (SEIA)

- Underwititers Laburaluries (UL) [3].

A discussion of some of the standards writing organizations active in the solar area, which are members of ANSI, follows.

American Society for Testing and Materials (ASTM). In June 1978, ASTM established a new committee on Solar Energy Conversion from two subcommittees-Space Simulations and Applications of Space Technology. The scope of the new committee, E-44, is:

The purpose of the committee shall be the promotion of knowledge, stimulation of research, and the development of standards concerned with the technology for conversion of solar energy to directly usable energy forms, and the application of such technology for the public benefit.

The areas of interest shall encompass standards relating to methods and applications of solar energy conversion. These methods and applicutions shall include, but shall not necessarily be limited to, the following: heating of swimming pools and domestic hot water; active and passive space heating and cooling; process heating; thermal conversion power generation; photovoltaic generation of electricity; wind energy conversion; ocean thermal energy conversion; biomass conversion; and advanced energy conversion. Consideration shall be given to applicable materials, components, subsystems, and systems in each of these methods and applications. 
This committee will serve as a coordinating agency for these activities and will maintain liaison with Committee E-21 on Space Simulation and Applications of Space Technology, and other relevant ASTM committees and technical organizations.

Areas of standards development applicable to this scope, but under the jurisdiction of other ASTM Committees, are excluded from development by this committee unless those other groups do not choose to act directly on the development of the specific standards which Committee E-44 determines to be necessary. In such cases Committee E-44 may elect to develop the needed standards with the appropriate liaison assistance of those other groups [6].

The committee will address standards for each solar technology, as well as for nomenclature and definitions, environmental parameters, safety, and materials performance.

By its bylaws, the committee must develop standards through procedures approved by the society: development of drafts at the task group level, balloting at the subcommittee level, balloting at the main committee and society levels, and procedural approval by the ASTM Board of Directors. Standards-writing must be in accordance with the procedures for the resolution of negatives, balance of voting interests, due process, timely notice of meetings, and adequate maintenance of records.

ASTM A-11 on rubber and rubber-like materials also has standards-development applicable to solar; for example, rubber seals.

The Institute of Electrical and Electronics Engineers (IEEE). IEEE is a scientific, engineering, and educational society; it does not develop standards for specific devices or hardware used in rating and labeling programs, or for warranties. It does, however, develop standard definitions, methods of tests, temperature limits, recommended practices, and safety guidelines. No IEEE committee is specific to solar technology applications; however, in related areas such as storage and power generation, IEEE traditionally has been quite active [7].

The American Society of Mechanical Engineers (ASME). ASME is a professional society for the advancement of technical knowledge and education for mechanical engineers as well as for the development of standards. The ASME Solar Energy Standards Committee, a voluntary consensus group, is developing standards with a focus on mechanical performance, design, and safety [7].

The American Society of Heating, Refrigeration, and Air Conditioning Engineers. ASHRAE, a technical, engineering, and educational society has two standards fully developed measuring thermal performance for solar. Two more standards are under development, one for swimming pool collectors and one for solar hot water systems.

\subsubsection{Participants in Solar Standards Writing}

Standards development is occurring for the solar technologies because of needs expressed by participants involved in the technology delivery system: architects; builders; 
distributors; engineers; federal, state, and local governments; financial institutions; installation contractors; labor unions; manufacturers; model code groups; research institutes; testing laboratories; and users (including end-use consumers, building developers, government demonstration project purchasers, and utilities). Each of these groups has an interest in the development of solar standards, and each is interested in their use in building codes and certification programs. Understanding of the participants' needs and interests will contribute to an improved comprehension of their roles in developing standards that effect solar technologies.

What follows is a discussion of the participants and their particular needs for standards.

Architects. Architects use standards in every step of designing. They need to know the performance, reliability, durability, and safety aspects of materials and systems. Architects pave the way for many solar technology applications as they and their clients are among the first users of many solar technologies. They become involved in standards development in the introduction stage (see Section 5.0 for a discussion of the commercialization stages), as the applications move from models to prototype to actual use. An institution representing architects is the American Institute of Architects.

Builders. Construction is a local activity, and builders usually have to operate by different sets of rules in different building code jurisdictions. The building codes cite the standards which builders should help draft. The National Association of Home Builders is one institution representing builders' interests.

Distributors. Distributors sell systems, from wholesalers to large retailers and to neighborhood hardware stores. They need to know what they are selling, and they have an obligation to the huying puhlir. They need reliable information to pass on to customers and to prevent salespeople from promising unreasonable levels of performance. Distributors do not become involved until the diffusion stage of commercialization. By this time, systems are marketed through existing distribution channels rather than on a case-by-case basis.

Kngineers. Engineers write the initial design and procurement specifications that later may become the basis for draft standards. Standards are a means for engine.prs to communicate specific requirements to each other and to manufacturers, users, and governments. With the continued development of a technolngy, engineers modify standards throughout the commercialization process. ASME, IEEE, and ASHRAE are. three of the institutions representing engineers.

Federal, State, and Local Governments. The public sector has a stake in the standards development process both to protect consumers and to support growth and development of private industry. State and local governments, through building codes, administer most standards developed for solar technologies as discussed in Section 3.0. The federal government has traditionally relied on the private sector for standards development except for the operation of NBS. NBS works to answer technological questions in support of administering a number of federal policies, including energy. It has developed a substanial portion of the standards for solar heating and cooling and for solar hot water. DOE, HUD, and the government laboratories are involved in all stages of the solar comm ercialization process. 
Financial Institutions. Before a lender approves a loan, he wants assurance of a return on his investment. Although lending institutions rarely become involved in standards writing, they are interested in the promulgation and use of standards. Standards give lenders an assurance of product performance.

Installation Contractors. Recommended practices for installation are operational guidelines for installation contractors. The group's interest in solar technology is expanding as the potential for contracts expands. Installation contractors become involved in the introduction stage. As the opportunities for contracts develop, so does the need for installation guidelines. The Solar Energy Industries Association (SEIA) is one organization representing these interests.

Insurance Companies. Insurance companies have a stake in solar applications. They need information or reliability, durability, and safety in order to protect their risks. Insurance company involvement in the writing of specifications and standards, mainly in the introduction stage, will increase as the use of solar technology expands.

Labor Unions. Labor unions have a paramount interest in solar technology. They not only represent a substantial segment of the buying public but also install components, subsystems, and systems, and may be involved in production. The AFL-CIO Building Trades Council represents labor interests, but each union, from the sheet metal workers. to the carpenters, has a stake in properly installed solar enegy applications. Unions need to be involved in writing recommended practices for installation, as these are operational guidelines for them. One improperly installed system may do more harm to the industry and its infrastructure than the good achieved by many well-done systems. Labor unions are not involved until late in the commercialization process when systems are installed on a broad scale.

Manufacturers. Manufacturers are involved in the standards development process at all stages of commercialization. Their needs are perhaps the greatest of all of the participants. They must not only communicate with users, purchasers, and suppliers, but must operate in a highly competitive atmosphere that may also be highly regulated. It is necessary to develop a language that will allow for establishing a strong indusry infrastructure. After a product is sold, the manufacturer's responsibility does not stop. This continuing responsibility is generally expressed in specific provisions of warranties. The solar energy industry manufacturers have established their own trade association which is SEIA. Other associations are also interested; for example, ARI.

Model Code Groups and the Building Code Community. The building code community is responsible for the interpretation and enforcement of code provisions on an almost caseby-case basis until code provisions are adopted for solar technology. Standards are the heart of every building code. Model code organizations and their consortium, the Council of American Building Officials ( $\mathrm{CABO}$ ), are examining new solar applications to determine a balance of solar technology promotion within the scope of promoting the health, safety, and welfare of building occupants.

Research Institutes. Research institutes operate under contract to clients in both the private and public sectors. The contracts generally cover the determination of the 
adequacy of products, systems, and services in the context of technological feasibility and market practicability. Standards are the language these organizations use. The institutes are involved in all stages of the commercialization process.

Testing Laboratories. Testing laboratories survive on the development and use of standards. They test materials, components, subsystems, and systems for manufacturers. They participate in the development of test methodology and standards, the instruments by which they operate. They are involved in all stages of the commercialization process.

Users. Users include both the end-use consumer and the purchaser who buys the product, system, or service as part of a package (for example, a housing developer is a user). Also included are government entities who purchase systems for use in demonstration programs. Users need a common language with the manufacturers. They need standards as assurance of the performance, reliability, durability, and safety of purchases. The National Consumers' League (NCL) represents users, as do public interest groups such as the Solar Lobby. Except for goverment purchasers, users generally enter the commercialization process in the introduction stage. Their participation is hampered by lack of funds and expertise in emerging technologies. 


\section{SECTION 3.0}

\section{BUILDNG CODES DEVELOPMENT PROCESS}

\subsection{INTRODUCTION}

There are over 5,000 building codes in force in the United States at present. Each state and local jurisdiction with a building code uses it as a tool to provide the minimum requirements necessary to promote health, safety, and welfare as well as the protection of property. Building codes are omnipresent and will affect the solar industry as they have affected other elements of the building industry. Building codes that accommodate solar technology are the key to ensuring the acceptance of solar devices and applications by building inspectors, who are checkpoints between the manufacturer/owner/builder and the end-use consumer.

\subsection{DEFTNTIONS}

A building code is a set of rules and regulations that builders must meet in order to have construction plans approved by the local or state building code authorities. The codes are comprised of definitions and standards for materials, products, system, and services, together with provisions for enforcement [8]. The authority for enforcement is derived from each state's police power. Codes regulate design, construction, prefabrication, equipment or appliance installation, quality of materials, use and occupancy, and location and repair of buildings.

Adopted codes usually reflect, in whole or in part, model codes developed to promote some degree of uniformity in the state and local building codes.

The three principal model codes and their developing organizations are:

- the Basic Building Code, developed by the Building Officials and Code Administrators International, Inc. (BOCA);

- the Standard Building Code, developed by the Southern Building Code Congress International (SBCCI); and

- the Uniform Building Code, developed by the International Conference of Building Officials (ICBO).

Each model code has a measurable influence on the local codes adopted in different regions of the country. The Basic Building Code permeates the Northeast, the Southern Building Code the South, and the Uniform Building Code the West. A fourth model code, the National Building Code developed by the American National Insurance Association (AInA), has a moderate degree of influence around the country excluding the west. AInA is not a model code association, but rather represents a collection of insurance interests which joined forces to minimize underwriting risks [8].

The model building codes are supplemented by other codes for plumbing, mechanical installations, electricity, elevators, flammable liquids, fire prevention, and exits. 


\subsection{PROCESS OF BUILDING CODES DEVELOPMENT}

Many interests are represented in the code development process including: architects; builders; distributors; engineers; federal, state, and local governments; installation contractors; insurance companies; labor unions; manufacturers; the model code group members; research institutes; testing laboratories; and users (including end-use consumers, building developers, and government demonstration project purchasers). These same participants are involved in the standards setting process.

Membership in the model code groups is open to any of these interests. The model code associations operate on a committee basis. Changes in materials, products, systems, or specifications are considered by the committee. Upon the committee's recommendation, changes are voted upon by the membership. How a committee member votes depends upon the interest he or she represents. For example, when polyvinyl chloride (YVC) pipe first appeared on the market its inclusion in the model codes was opposed by the cast iron pipe interests. Both PVC and cast iron pipe can be used in the same applications, and both interests fight for the same market [2].

Changes in local or state codes, unless mandated by legislation, are made at the time of review or on a case-by-case basis. Changes are brought about as vested interests and general interests (represented by local, state, and federal governments) participate in the code development process. The response of model code associations and local code authorities to changes in technology involves a long and arduous process, mainly because of the number of local codes. The standards writing organizations provide the standards for codes, and the transfer process from standard to code is not a quick procedure. Testing and approval by model code associations and the local code authorities extend the time required for implementation.

The building industries have long operated within the traditional institutional framework for standards and building codes development. Energy policy makers have been employing this framework for solar energy applications as well as for other new technology applications. 


\section{SECTION 4.0 \\ CERTIPICATION PROGRAM DEVELOPMENT PROCESS}

\subsection{INTRODUCTION}

Certification programs serve $\mathbf{a}$ number of functions, primarily testing in accordance with a referenced standard to measure characteristics that may include but are not limited to performance, reliability/durability, and safety. Affixing a mark or a label after testing transmits information that the consumer/user needs to know about the product or system. It aids in establishing the credibility of manufacturers' claims, which in turn aids in establishing consumer confidence. Certification promotes a means of communication between manufacturers and consumers/users.

Sound certification programs based on a consistent set of referenced standards are necessary for some solar technology applications. The following provides definitions as well as a brief explanation of the process of developing certification programs. Specific solar certification programs are discussed in Appendices B through $\mathrm{H}$.

Before testing laboratories can certify products, they must be accredited to do so. This requires an evaluation and approval of the laboratories' facilities by approval bodies. This may occur privately or through NBS in its laboratory accreditation program.

\subsection{DEFINITIONS}

\subsubsection{American National Standards Institute}

Certification programs traditionally have been developed in the private sector under voluntary consensus procedures. The American National Standards Institute (ANSI) serves as the umbrella organization for the accreditation of certification programs developed under voluntary consensus procedures. The Air Conditioning and Refrigeration Institute (ARI), the American Gas Association (AGA), the National Electrical Manufacturers Association (NEMA), Underwriters Laboratories (UL), and others have at specific times and for certain products developed programs to verify that a product meets specific standards.

Through the years, these organizations have determined certain general requirements necessary to the development of an effective certification program. First, the process should be voluntary. Secondly, the program should be open to all manufacturers able to meet the criteria. Finally, no conflict of interest should surround the creation and implementation of an industry-promulgated program.

Because most certification programs are based on ANSI procedures, the following definitions used in this report are based on ANSI definitions.

- "Certification": The product is attested by the manufacturer, under the procedures of a certification program, as having met the specific requirements of a referenced standard [9]. 
- "Certification Program": An organized system under which, on a uniform and equitable basis, similar products of any number of producers or suppliers may be determined to meet specified standards [9].

\subsubsection{Underwriters Laboratories}

UL does not use the term "certification"; however, each service they provide is based on compliance with a standard as determined by testing. UL tests to determine product safety. The four types of UL determination (services) listed below deal with various types of systems or components. Definitions of each service are included here to illustrate the relatively fine differences in terminology used by different organizations (or in this case even by the same organization) [10].

- "Classification Service": A system whereby UL determines that a manufacturer has demonstrated the ability to produce a product (usually industrial or commercial) that complies with UL's's requirements for the purpose of classification or evaluation, with respect to one or more of the following: (1) specific hazards only, (2) performance under specified conditions, (3) regulatory standards or codes, (4) other standards including international standards, or (5) such other conditions as UL may consider desirable. By terms of the Classification and Follow-Up Service is conducted by UL as a check on the means used by the manufacturer to determine compliance with the UL requirements [10].

- "Certification Service": A service applicable to field-installed systems, or to specific quantities of certain products intended for use at specified locations, where it is impractical to apply the Listing Mark or Classification Marking to the individual product [10].

- "Listing Services": In this sytem UL determines that a manufacturer has demonstrated the ability to produce a product that complies with UL requirements with respect to reasonably foreseeable hazards. By the terms of the Listing and Follow-Ûp Service Agreement, the manufacturer is authorized to use the IIT, Tisting Mark on prndinets that comply with UL's requirements. A FollowUp Service is conducted by UL as a check on the means used by the manufacturer to determine compliance with UL requirements [10] .

- "Recognition Service": A system whereby UL determines that a manufacturer has demonstrated the ability to produce a component for use in an end product that complies with UL requirements. This takes into account the performance and construction of such end products insofar as they can be determined and the areas requiring additional consideration for application of the component to the product. By the terms of the Recognition and Follow-Up Service Agreement, the manufacturer is authorized to use the Recognized Marking on products that comply with UL requirements. A Follow-Up Service is conducted by UL as a check on the means used by the manufacturer to determine compliance with UL requirements $[10]$.

\subsubsection{Quality Control Programs}

Generally, certification is not intended to ensure the quality of a product beyond specific certification criteria. A quality control program is a manufacturing tool for product uniformity and manufacturing efficiency. It is necessary if the manufacturer wants to compete effectively in the marketplace. The consumer/user should be able to determine 
from the results of the program that the product is potentially reliable and that it meets the specific manufacturer's standards for determining quality. Neither certification nor quality control programs can be used for direct marketplace comparison of similar products [10].

\subsubsection{Rating Systems}

Ratings are included in many certification programs and therefore are developed by the same organizations. A rating system generally is not a grading system that allows the consumer/user to compare the overall qualities of a product, but rather allows comparison of performance or size requirements for particular applications. There are some rating systems which do allow consumer/user comparison. Rating indicates that the product complies with a standard and, therefore, may product a certain result. Ratings are a tool which the consumer/user may use to determine that the product can perform its intended function (i.e., size and power of an air conditioner for a specific room size) [10].

\subsection{PROCESS OF CERTIFICATION PROGRAM DEVRLOPMENT}

Certification programs require several elements for operation. The sponsor is an organization that takes the responsibility for developing, promulgating, and managing the program. A validator, who may be the same as the sponsor, is needed. Validation is the process by which a separate determination is made that the certification by the manufacturer or vendor is in fact in accordance with the requirements. Often the validator is an independent third-party testing laboratory whose function is to administer the standards. Standards are necessary as the basis for measuring the certification criteria. The first users of the certification program, the manufacturers or vendors, are known as "licensees.". Pending certification of their products or systems, they are authorized by contract to use the certification mark:-

The development of a certification program is usually spurred by a variety of needs expressed by manufacturers, or consumers, or by Congressional or state mandate. Following initial discussions among industry members, a program sponsor is chosen who sets in motion the steps necessary for program implementation. These steps include writing guidelines for accrediting validators, selecting referenced standards used to measure the product's characteristics, writing guidelines and procedures for operation of the program, seeking ANSI accreditation of the program, and registering the certification mark with the federal government.

Several key issues need to be addressed in the development of such programs. One important issue is establishing the need for the program and deciding upon its value to consumers/users and its impact upon the industry. An issue that surfaces frequently in the solar technologies is the availability of standards. For example, there are no overall system performance measurement techniques for solar systems. Conflict of interest considerations must be addressed and eliminated. In addition, participation in the program must be equally available to any manufacturer or vendor of the products or services. The fee structure must be established so that the operational costs are covered without excluding small businesses. A review procedure must be established to maintain the credibility and efficacy of the sponsor and the validator, the referenced standards, and the manufacturer or vendor. The establishment of certification programs is somewhat easier than the maintenance of technical and procedural credibility. 
TR-095

\section{SEPㄴ?}




\section{SECTION 5.0}

\section{COMMERCIALZATION AND STANDARDS}

\subsection{DEFINITIONS}

SERI's working definition of commercialization of a solar technology is:

essentially the process of moving a new type of energy system from the technological feasibility stage to a status of market acceptance and significant use. [11]

The factors involved in commercialization have been articulated by the MIT Energy Laboratory as:

(1) the market price of labor and material inputs; (2) the relevant cost of capital; (3) the market price of energy; and (4) taxes, legal restrictions on the relevant production possibilities, or other government intervention . . . commercialization of a new technology will take place if it is available at a cost that allows the private sector an acceptable rate of return on the capital required. [1 2]

Four phases comprise the commercialization process: applied research, development, introduction, and diffusion. Overlap between these phases is the rule rather than the exception because feedback from technological progress can cause a technology to revert to a previous phase.

APPLIED RESEARCH is the phase in which plans are developed for applying basic research. Activities in this phase include experimentation, data collection and analysis, and laboratory-scale feasibility demonstrations [10]. Activities concerning standards in this phase are: cataloging of user requirements, identification of performance characteristics to be measured, the beginning of test method development, identification of reliability/durability issues, identification of hazards, and analysis of the applicability of test methodology from other technologies. For further discussions of standardsdeveloping activity, see Tuble 5-1 and Figure 5-1.

The DEVELOPMENT phase involves commitment of large investments to the project, leading to the production of bench models [10]. Standards activities in this phase include: beginning voluntary consensus standards activities, developing user requirements, laying the groundwork for establishing definitions, identifying performance characteristics, developing test methodology, and developing design criteria. Also included is the development of methodology for measuring reliability and durability characteristics, both by real life and accelerated life testing. Analysis and writing of safety guidelines begin in other standard areas. The establishment of laboratory accreditation procedures surfaces as an issue.

Full-scale production begins in the INTRODUCTION phase, requiring an acceptable productivity rate and quality assurance [10]. More participants enter the voluntary consensus process. Definitions are refined. Definitive performance characteristic measurements and design specifications are developed. Real life performance tests and accelerated life tests continue for the measurement of reliability/durability characteristics. As laboratory accreditation gets underway, product certification programs begin to 


\section{Table 5-1. STANDARDS DEVELOPMENT ACTIVITIES IN THE COMMERCIALIZATION PROCESS}

\section{Event}

Explanation - What questions do these activities answer?
I. Applied Research

A. Catalog User Requirements

B. Modification of Existing

C. Identify Performance Character istics

D. Begin Test Method Development

E. Identify Reliability/ Durability Issues

F. Identify Hazards

G. Begin Data Accumulation

II. Development

A. Enter the Voluntary Consensus Process

B. Develòp User Kequirements

C. Begin Definitions

D. Interim Performance Criteria Measurements

E. Interim Design Criteria

F. Reliability/Durability Real Life Testing
For what use can this product, system, or service be developed? What needs will this fill?

Are these standards, i.e., test mothode, definitions from other technologies that can be applied?

What is it the user needs to know about this?

How can the performance characteristics be measured

How long will it last? What kind of environmental ștresses can it endure?

How safe is it? What potential problems will its use liave on people and the environment?

What do we need to know about this? What will the numbers say?

Are American National Standards needed?

The gathering of data yields more information. Are there any otlier applications for this?

What is the language the actors need to communicate with?

What does the use of this yield?

What are the dimensions of this?

How long will this last? How does it withstand environmental stress? 


\section{Table 5-1 (cont.)}

Event

G. Reliability/Durability

Accelerated Testing

H. Safety-Begin Hazards Analysis

I. Safety-Begin Guidelines

J. Address Laboratory Accreditation

III. Introduction

A. Enter the Voluntary Consensus Process

B. Refine User Requirements

C. Develop Definitions

D. Definitive Performance Characteristics

E. Definitive Design Criteria

F. Reliability/Durability Real Life Testing

G. Reliability/Durability Accelerated Testing

H. Safety, Hazards Analysis
Explanation

How can we quickly determine its ability to withstand environmental stress? What will happen in five years? Ten years? Twenty years? When will it wear out?

From use and from prior experience with the materials and components, what is known about the hazards of use to people? To the environment?

From the analysis of hazards how can guidelines for safe use and/or operation be developed?

What independent, third-party testing laboratories are qualified to test and measure performance and related issues?

Are American National Standards needed?

How will this be used? How can the need for this be expressed?

What language is needed for coummercialization?

How does this perform? Is there confidence in the level of performance expressed?

What are the dimensions of this? Are the parts interchangeable?

How does this withstand stresses from field installation and operation?

How can information be quickly obtained on the lifetime performmance? How long will it last?

Are there any other hazards associated with use? 
Table 5-1 (cont.)

I. Safety Guidelines $^{\circledR}$
J. Laboratory Accreditation
K. Product Certification
L. Recommended Practices:
Installation
M. Recommended Practices:
N. Operation
Decommended Practices:
Diffusion
A. Definitions
B. Specifications: Performance
C. Specifications: Design
D. Test Methodology: Functional
E. Test Methodology: Mechanical

F. Durability/Reliability: Materials and Components

G. Durability/Reliability:
Subsystems/Systems
How can this be safely installed, operated, and maintained?

What laboratories are qualified to test the characteristics of this?

Has this been tested? Does it meet the tests?

How should this be installed?

How should this be operated and/or used?

How should maintenance and servicing be done? How of ten?

Is the language adequate for clear rnmmunirertion?

Can the characteristics of this be specified?

Can the purchaser tell the manufacturer exactly what is needed? Its dimensions? Its limits?

Are there standard test methods for measuring performance?

Are there standard test methods for measuring the adequacy of the mechanical configurations?

Are there standard test methods for measuring the durability and reliability of the materials and components?

Are there standard test methods for measuring the durability and reliability of the subsystems and systems? 
Table 5-1 (cont.)

\begin{tabular}{|c|c|c|}
\hline & Event & Explanation \\
\hline H. & Safety-Hazards Analysis & $\begin{array}{l}\text { Is all information available on } \\
\text { hazards? }\end{array}$ \\
\hline I. & Saf ety-Guidelines & $\begin{array}{l}\text { Are there standards for the safe use } \\
\text { and/or operation of this? }\end{array}$ \\
\hline J. & Laboratory Accreditation & $\begin{array}{l}\text { Which independent third party labora- } \\
\text { tories are accredited to test the } \\
\text { product, system, or service? }\end{array}$ \\
\hline $\mathrm{K}$. & $\begin{array}{l}\text { Product Certification: } \\
\text { Labeling }\end{array}$ & $\begin{array}{l}\text { How can it be determined if this has } \\
\text { met the test? }\end{array}$ \\
\hline L. & $\begin{array}{l}\text { Recommended Practices: } \\
\text { Installation }\end{array}$ & $\begin{array}{l}\text { Are the practices consistent and } \\
\text { unifor } m \text { ? }\end{array}$ \\
\hline M. & $\begin{array}{l}\text { Recommended Practices: } \\
\text { Operation }\end{array}$ & $\begin{array}{l}\text { Are there consistent guidelines for } \\
\text { safe and effective operation and/or } \\
\text { use? }\end{array}$ \\
\hline N. & $\begin{array}{l}\text { Recommended Practices: } \\
\text { Maintenance }\end{array}$ & $\begin{array}{l}\text { Are there consistent guidelines for } \\
\text { the scheduling of maintenance? How } \\
\text { should maintenance be performed? }\end{array}$ \\
\hline O. & Building Code Citation & Can building inspectors approve this? \\
\hline
\end{tabular}




\begin{tabular}{|c|c|c|c|c|c|c|c|c|c|c|c|c|c|c|c|c|c|c|c|c|c|c|c|c|c|c|c|c|c|c|c|c|c|c|c|c|}
\hline$\varepsilon$ & APPLI & IEC & & & & & & 10 & of & & & & & & & & & & ITROD & & & & & & & & & & & & frusion & & & & & \\
\hline $\mid \begin{array}{c}E \\
N \\
I \\
S\end{array}$ & 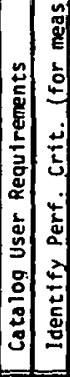 & 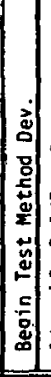 & & 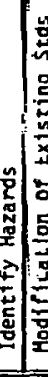 & & 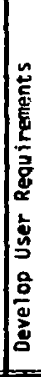 & 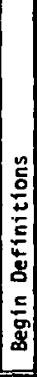 & & $\frac{5}{5}$ & $=$ & 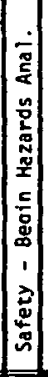 & & 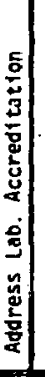 & 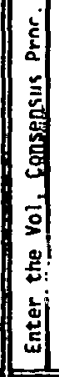 & & 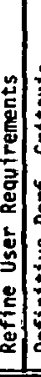 & \begin{tabular}{|ll}
0 \\
0
\end{tabular} & 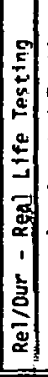 & & 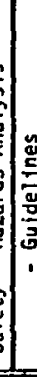 & & & 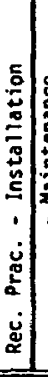 & & 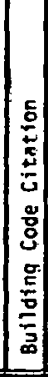 & $\mid \begin{array}{l}n \\
0\end{array}$ & 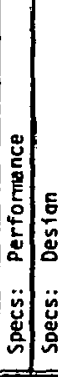 & 5 & 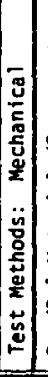 & $\begin{array}{c}0 \\
\vdots \\
\vdots \\
\vdots \\
\vdots\end{array}$ & 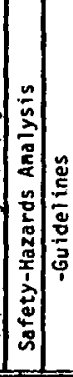 & 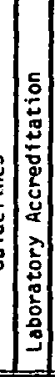 & & 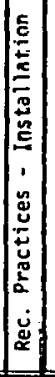 & & . \\
\hline ITECT & & & & & & & & & & & & & & $\mid x$ & & $x$ & $x$ & $x$ & & $x$ & & $x$ & $x$ & & & t & $x \mid x$ & & & & & & & & & $x$ \\
\hline LOEER & & & & & & & & & & & & & & $x$ & 1 & & $x$ & & & \begin{tabular}{|l|l}
$x$ \\
\end{tabular} & & & $\bar{x}$ & & & 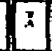 & \begin{tabular}{|l|l}
$x$ & $x$ \\
\end{tabular} & $x$ & \begin{tabular}{|l|l|}
$x$ \\
\end{tabular} & \begin{tabular}{|l|l|}
$x$ & \\
\end{tabular} & \begin{tabular}{|l|l}
$x$ & $x$
\end{tabular} & & & $x$ & & $\bar{x}$ \\
\hline IF 18 & & & & & & & & & & & & & & & & & & & & & & & & & & 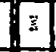 & \begin{tabular}{|l|l}
$x$ & $x$ \\
\end{tabular} & & & \begin{tabular}{|l|l|}
$x$ & $x$ \\
\end{tabular} & $x$ & & & $x \stackrel{5}{3}$ & \begin{tabular}{l|l}
$x$ & \\
\end{tabular} & $\begin{array}{lll}x & x \\
\end{array}$ \\
\hline & & & & I. & & & & & & & & $x$ & & $x]$ & 1 & 1 & $x$ & $x$ & $x$ & d] & 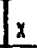 & $x$ & $x$ & $x$ & & $\dot{i}$ & \begin{tabular}{|l|l}
$x$ & $x$ \\
\end{tabular} & & $x$ & $x$ & $x$ & $|x|$ & & $x$ & $x$ & \begin{tabular}{l|l}
$x$ & $x$ \\
\end{tabular} \\
\hline & & & & & & & & & & & & & & & & & & & & & & & & & & & & & & & & & & & & \\
\hline & & & & & & & & & & & & & & $x$ & & & & & $x$ & & & $x$ & $x$ & $x \mid x$ & & & & & & & \begin{tabular}{|l|l}
$x$ & \\
\end{tabular} & & $x$ & $x$ & & $x$ \\
\hline SUI & & & & & & & & & & & & & & $\| x$ & & & & & 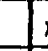 & 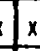 & & $x$ & & & & $x$ & & & & \begin{tabular}{|l|l|} 
& $x$ \\
\end{tabular} & \begin{tabular}{|l|l|}
$x$ & $x$ \\
\end{tabular} & & $x$ & & & \\
\hline $\mathrm{ABO}$ & & & & & & & & & & & & & & & & & & & & & & & $x$ & & $t^{\prime}$ & & & & & & & & & \begin{tabular}{|l|}
$x$ \\
\end{tabular} & & x \\
\hline ANUF F & $x$ & & $x$ & & & $x$ & & $n$ & $x \mid x$ & $x$ & $\mid x$ & $x \mid$ & & 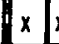 & $x$ & $x$ & \begin{tabular}{l|l}
$x$ & $x$
\end{tabular} & $|x|$ & $\times 1$ & $x$ & $x$ & & $x$ & \begin{tabular}{l|l}
$x$ & $x$
\end{tabular} & & $x$ & $\begin{array}{lll}3 & x\end{array}$ & & $x$ & $\begin{array}{l}x \\
x\end{array}$ & \begin{tabular}{|l|l|}
$x$ & $x$
\end{tabular} & \begin{tabular}{l|l}
$x$ & $x$
\end{tabular} & $x$ & $x$ & \begin{tabular}{l|l}
$x$ & $x$
\end{tabular} & $\begin{array}{l}x \\
x\end{array}$ \\
\hline & & & & & & & & & & & & & & & & - & \begin{tabular}{|l|l}
$x$ & $x$ \\
\end{tabular} & & & & & & $x$ & & $x$ & $x$ & $x \sqrt{x}$ & & & $x$ & \begin{tabular}{|l|l}
$x$ & $x$ \\
\end{tabular} & & & $x$ & & $x$ \\
\hline & & & $x$ & $x$ & & & & 4 & & $x$ & & $x$ & & $x$ & $x$ & & & $x$ & 1 & 4 & & & & $x$ & & $x$ & \begin{tabular}{l|l}
$x$ & $x$ \\
\end{tabular} & $x$ & 12 & \begin{tabular}{|l|l}
$x$ & $x$ \\
\end{tabular} & $x$ & & & & $a x$ & $x$ \\
\hline ABS & & & $-\underline{x}$ & & & & & & 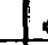 & $x$ & $x$ & & & & & & & $x$ & & & & & $x$ & & & & $x$ & $x$ & 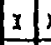 & \begin{tabular}{l|l}
$x$ & $x$ \\
\end{tabular} & $x$ & $x$ & & & $x$ & \\
\hline ERS & & & & & & & & & & & & & & $x$ & & & & & & & & & & & & & & & & \begin{tabular}{|l|l}
$x$ & $x$ \\
\end{tabular} & & & & & & \\
\hline
\end{tabular}

Figure 5-1. DESCRIPTION OF STANDARDS EVENTS IN COMMERCIALIZATION 
develop. Concerned participants begin devising recommended practices for installation, operation, and maintenance of systems. Building codes begin to recognize the new technology applications.

Reaching the DIFFUSION stage depends upon development of an industry infrastructure and consumer acceptance of the technology applications. The first successful companies are followed by imitators in this stage [11]. Although subject to change and revision, standards stabilize during this stage. Definitions are established, and performance and design specifications are more advanced. Functional and mechanical test methodologies have been established. Techniques are available for measuring durability and reliability of materials, components, subsystems, and systems. Hazards analysis is mature, and guidelines for the safe operation and maintenance of products of systems have been developed. The standards are implemented through self-regulation by the industry in product certification programs and through citation in model building codes and those adopted at the state and local levels.

\subsection{STANDARDS ISSUES IN THE COMMERCIALEATION PROCESS}

Part of the uncertainty in developing a new technology is a function of the lack of consistent regulations for use of the technology. Technology failures "can be more or less directly traced to a lack of knowledge, or failure to address institutional issues" [12]. Institutional issues in the development of standards are:

- Who would develop them?

- When should they be developed?

- How should they be developed?

- Whom will they affect?

In each stage of the commercialization process the participants must examine the process and the kinds of standards needed (see Section 2.0 for a discussion of the participants). If standards are developed too early, they may inhibit industry growth. Further, if lifetime performance criteria are determined in the development phase, cxpeotations may arise without sufficient support. Such standards may also limit the development of systems with better life-cycle costs but shorter lifetimes, which could exclude low-technology solutions.

Conversely, if the industry does not begin testing for lifetime performance characteristics in the development phase, it will be unable to develop standards for certification programs in the market introduction phase. This, too, can be harmful. Thus, standards activitics in the context of a government push for accelerated commercialization must be carefully designed to mitigate negative effects. These activities should be designed to raise consumer confidence and to support the development of a strong industry infrastructure.

The voluntary consensus system has been active in this country for over 75 years, and has worked satisfactorily for many other technologies. It appears that changing the system by which standards are to be developed for solar technologies is not warranted. The government's reliance upon the voluntary consensus system is discussed in Section 6.0. 


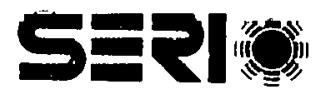




\section{SECTION 6.0}

\section{FEDERAL POLICIES IN STANDARDS, BUILDING CODES, AND CERTIFICATION PROGRAMS}

Federal government activities, specifically those of HUD, DOE, and NBS, are discussed at length in the appendices. Government activities in support of the development of standards, building code provisions, and certification programs must be seen in the light of accelerated commercialization of the solar technologies. Policies on development activities are discussed in this section in relation to government methods. These policies use the traditional institutional framework to speed the development process. For example, standards development normally can take from two to five years. On an accelerated basis, that time can be reduced by as much as one-third to one-half.

\subsection{GOVERNMENT SUPPORT POR THE STANDARDS DEVELOPMENT PROCESS}

A circular published in the Federal Register by the Office of Management and Budget (OMB) describes interaction of government employees with the voluntary consensus system. The circular is reproduced as Appendix I.

There are four means by which government supports the development of standards, building codes, and certification programs:

- direct financial support through grants, sustaining memberships, and contracts;

- administrative support through subsidizing travel costs, hosting meetings, and providing secretarial functions;

- technical support through cooperative testing for standards evaluation, and participation of agency personnel on standards committees; and

- joint planning with the voluntary standards community to ensure a coordinated effort in resolving important standardization problems [13].

\subsubsection{Direet Financial Support: Grants, Sustaining Memberships, and Contracts}

DOE has given a grant of $\$ 36,000$ to ASTM E-44 to increase the frequency of meetings to resolve negative votes on the balloting of draft standards. These funds will supply travel money to consumers and representatives of small business, universities, and state and local governments.

Representatives from all federal agencies serve on standards writing committees and are entitled to vote on balloted draft standards (pending each agency's policy on voting). In addition to allowing technical participation, memberships also cover some operating costs of committee administration.

A federal agency may contract with a standards developing body to develop standards to supply particular needs and may provide financial support. For example, HUD and the Sheet Metal and Air Conditioning Contractors' National Association, Inc. (SMACNA) worked together to develop installation standards for solar heating and cooling systems in the market introduction phase. 


\subsubsection{Administrative Support: Travel Cost, Hosting of Meetings, and Secretarial Functions}

Agencies reimburse the travel expenses of employees serving on committees. Often standards development activities are national in scope; committees meet throughout the nation. Without travel cost reimbursement it would be immensely difficult for federal representatives to attend meetings. The alternatives, communication via mail and telephone, are less than optimal.

Federal agencies can offer their facilities for committee meetings to alleviate the cost of meeting space in hotels and other public facilities. On occasion, the ANSI SSSC uses meeting space at DOE in Washington, D.C.

The administrative burdens of committees consume time and money in publishing meeting notes, distributing and maintaining records (minutes), and mailing letter ballots and draft documents. Spreading this cost through members alleviates the burden on any one body. The ANSI SSSC, at its November 1978 meeting, voted to accept administrative support from DOE and HUD. This will be accomplished via a contract from DOE to ANSI.

\subsubsection{Technical Support: Cooperative Testing Standards Evaluation and Participation of Agency Personnel on Standands Committees}

Cooperative testing for standards evaluation refers to the use of government laboratories to validate test methods and to cooperate in round-robin testing. The keys to the efficacy of a standard test method are its reproducibility and repeatability, which allow it to be used in a variety of operations under the same conditions. This kind of support reduces the burden on the private sector-a particularly crucial factor in the development phase, when reliable and accurate standards are most needed. In the accelerated commercialization of the solar technologies, data accumulation by government laboratories through cooperative testing encourages industry to develop the tools (standards) that will contribute to technological and market feasibility.

Participation of agency personnel on standards committees allows federal expertise and experience to be shared with the private sector.

An important expediter of the standards-development process is the writing of draft standards. This activity gives the consensus organizations a base for their standardswriting. See Appendix B for a discussion of how this activity has worked to date.

\subsubsection{Joint Planning with the Voluntary Standards Community to Ensure Coordination in Resolving Standardization Problems}

This kind of effort can provide the organization and management necessary to accelerate the standards development process. An effective way to establish this effort could be modeled on the SERI-managed Coordinating Council for the Development of Performance Criteria and Test Methodology for Photovoltaics, or the joint efforts of NBS and ANSI leading to standards for solar heating and cooling. Such joint efforts coordinate elements necessary for accelerated standards development in the private sector. This activity should begin in the development or market introduction phases. 
1.

In preliminary stages of standards setting, participants reach general agreement on standards needs and priorities of test methodology development. Organizations having the capability to draft documents are identified. This activity can accelerate the process by concentrating efforts toward laying the groundwork for standards (draft test methods, criteria, or specifications) and then transferring results to the voluntary consensus community.

\subsubsection{Conclusion}

The federal government can accelerate the standards development process for solar technology in the private sector by supporting the traditional standards-setting process. Government agencies can and do provide financial, administrative, and technical support to the process. This effort leads to the attainment of two goals in commercialization: the development of an industry infrastructure and the encouragement of consumer confidence in systems and products.

\subsection{GOVERNMENT SUPPORT FOR THE BUILDING CODE PROCESS}

This section discusses the federal role in developing building code provisions for solar technology applications, primarily in the area of model building codes and their relation to those adopted at state and local levels. DOE's national program in support of developing provisions is described as part of accelerating commercialization of solar applications.

For both SHACOB and solar hot water, significant progress has been made in making building codes accommodate solar technologies. That experience has not been without difficulties, and it is anticipated here that people can learn from the experience to obtain smooth acceptance of other solar technology applications by building code inspectors.

The main problem in having building code provisions accommodate solar technology is the diversity of the codes, both the national model codes, and certainly those at the state and local levels. Public agencies and the building industry have been confronted by those disparities for many decades. During the administration of President Johnson, special commissions were appointed to investigate difficulties in providing decent housing for every family. The commissions concluded that the lack of building code uniformity increased construction costs and impeded the introduction of technical innovations [14].

Several recent developments in building codes point to a resolution of code disparities within the foreseeable future. At the national level, substantial improvements in the political arena surrounding codes have promoted joint efforts between the private and public sectors to obtain greater code uniformity. Current significant advances in energyrelated standards and codes may be precedents for overcoming building code barriers. Current federal policy seeks to use both the existing institutional framework for developing and revising code provisions and the improved cooperation among code groups to resolve disparities in their efforts. The existing institutional framework has been discussed in a previous chapter. The following brief review of recent developments illustrates the potential for eliminating many of the problems associated with code diversity. 


\subsubsection{Developments in the Model Code Associations}

The most influential force in building code development is the group of organizations representing the building code officials: BOCA, SBCCI, and ICBO. To serve their common interests, these three organizations established the Council of American Building Officials (CABO) in 1972.

In 1967, the National Conference of States on Building Codes and Standards, Inc. (NCSBCS) was founded as a nonprofit organization to increase interstate cooperation and to coordinate intergovernmental reforms of building codes. NCSBCS serves as a forum for discussing building regulations and public safety and as a representative in standards development by its members, which include state-appointed delegates, representatives of model code groups, state and local building regulatory groups, national standards organizations, industry, and consumers. NCSBCS coordinates the development of standards and code practices that encourage the introduction and uniform adoption of innovative building materials and practices.

NCSBCS, under contract to DOE and with the assistance of the model code groups, developed an energy conservation code for building construction in 1977. With the code were developed instructional materials for training building code inspectors in its implementation and enforcement. Since its publication, 22 states have either adopted or are in the process of adopting it. The stimulus for the code was Congressional legislation calling upon the states to enact energy conservation codes. This effort by NCSBCS will be superceded by the Building Energy Performance Standards (BEPS [16]; however, it does demonstrate cooperation between public and private code development efforts.

In May 1978, the executive directors of the model code associations met with their counterparts of the voluntary standards system, including ANSI, ASTM, ASHRAE, and ASME. Until that time building code organizations did not coordinate their activities nor did they seek acceptance of their work under the voluntary standards system. Discussions at this meeting concluded with agreement that the consortium of building code organizations in $\mathrm{CABO}$ would be recognized as the accredited organization responsible for developing and maintaining model building codes.

\subsubsection{DOE's Contract for a Model Solar Document and for Training Programs}

In the fall of 1978, DOE entered into a contract with CABO to develop a model solar document and training programs for building officials. The purposes in letting this contract are to promote:

- a uniforin sel of standurds on solur technology appllcations to be adopted by model codes and subsequently by state and local jurisdictions;

- a mechanism to ensure inclusion of solar provisions in codes in force; and

- a training program with instructional materials for building code inspectors.

The relevant portions of this contract are reproduced in Appendix $J$ (Contract for Development of Model Building Code Development). 


\subsection{GOVERNMENT SUPPORT FOR CERTIPICATION POLICIES}

As noted in Section 4.0, certification programs for solar collectors are under development in both the private and the public sectors: ARI, SEREF, California, and Florida. This proliferation of programs led to a significant decision by the ANSI SSSC at its November 15, 1978, meeting. The SSSC created a subcommittee to develop a means for establishing a thermal performance rating method for use in all collector certification programs. The subcommittee's report is due in June 1979. The SSSC has expressed the need to promote uniformity of test methods in certification.

The DOE position on solar equipment certification has been to work within the voluntary consensus system because this system provides the best method for accommodating diverse viewpoints, thereby encouraging widespread recognition and acceptance of the developed programs.

The federal government will continue to support the voluntary consensus system. In addition, widespread participation will be encouraged in order to bring about maximum adoption of the programs developed. At the same time, the federal government will encourage state or local certification programs to use the requirements existing on the national level [16].

As certification programs are developed, several factors should be considered. The approach should be comprehensive; that is, it should include public education, training of officials, and provision of information on the products tested and certified. Also, a national certification program must be flexible to accommodate regional diversity.

It should be clear at the outset that certification programs are used for purposes other than industry quality assurance. An example is the use of certification as an eligibility requirement for participation in a federal or state incentive program. These incentive programs are expected to increase; a link between them and national certification programs should be encouraged.

An additional concern involves the use of certification programs: they should not be used to discriminate against passive solar systems or low-technology, low-cost systems. Passive systems cannot be certified in the conventional sense; consumers, local officials, lenders, and others should not be left with the impression that these systems are second rate because of the lack of certification.

Several areas need further research. One is the impact of certification on the costs of solar components. Another is the extent to which certification programs frustrate innovation in a developing industry. An associated issue is the need to accommodate modifications to already certified components or systems. More information is also needed on the timing of the developinent of certificate programs.

Consideration should be given to the desirability and feasibility of federal or state subsidy programs for small manufacturers for whom the costs of testing and certification would be an extreme hardship.

While continuing support to ongoing certification activities, DOE must examine whether the issues most critical to consumers are addressed. For example, more attention might be given to the testing and certification of controls because of the widespread problems with these components. Also, more emphasis might be placed on providing system 
integration information and installation procedures because lack of these has caused numerous problems.

Policy planners for solar technologies should learn from the SHACOB experience that the lack of careful planning can lead to a proliferation of programs with conflicting requirements. DOE and HUD support of the ANSI SSSC activities on certification are a recognition of federal support to the voluntary consensus system and a merging of private and public sector interests to solve the problems associated with certification. 


\section{REFERENCES}

1. Bottaro, Drew. The Purpose and Role of Product Standards in the Commercialization of New Energy Technologies: A Preliminary Analysis; MITEnergy Laboratory Working Paper. Cambridge, MA: Massachusetts Institute of Technology; MIT-EL-78-023W P; October 1978.

2. Standardization Basics. Philadelphia, PA: American Society for Testing and Materials; 1974.

3. 1975 Annual Book of ASTM Standards. Philadelphia, PA: American Society for Testing and Materials; 1975.

4. National Bureau of Standards. Plan for the Development and Implementation of Standards for Solar Heating and Cooling Applications. Boulder, CO: NBS; NBSIR 78-1143A; 1978.

5. ANSI SSC Membership List, April 1978.

6. Minutes of the ASTM E-44 on Solar Energy Conversion meeting held in Philadelphia, PA; June 1978.

7. A Plan for the Development of Performance Criteria and Test Methodology for Photovoltaics. Golden, CO: Solar Energy Research Institute; January 1979.

8. Meeker III, Frank O. Building Codes as Barriers to Solar Heating and Cooling of Buildings. Environmental Law Institute; March 1977.

9. American National Standards Institute. American National Standards Institute Policy and Procedures \& Manual of Operations for Accreditation of Certification Programs. New York: ANSI; August 1976.

10. Mataset, Patricia; Heffner, Grayson. Certification Development, Draft. PRC Energy Analysis Co.; 1978.

11. Flaim, S.; et al. Economic Feasibility and Market Readiness of Solar Technologies, Volume 1, Draft Final Report. Golden, CO: Solar Energy Research Institute; September 1978.

12. Government Support for the Commercialization of New Energy Technologies, an Analysis and Exploration of the Issues. Cambridge, MA: MIT Energy Laboratory; MIT-EL 76-009; November 1976, p. 5.

13. Proposed OMB Circular on Interaction with Voluntary Consensus StandardsDeveloping Bodies, Federal Register. 43 FR 48-51; January 3, 1978. 
14. Field, Charles G.; Rivkin, Steven R. The Building Code Burden. Lexington, MA: Lexington Books; 1975.

15. DOE Advance Notice of Proposed Rule Making: Energy Performance Standards for New Buildings, Title 10, Code of Federal Regulations, Part 435, Federal Register; November $21,1978$.

16. Conversation with David Pellish, Office of Conservation and Solar Applications, DOE; August 1978. 


\section{BIBLIOGRAPHY}

\section{BOOKS}

American Society for Testing and Materials. ASTM in the Voluntary Standards System of the, U.S.A. ASTM, 1916 Race St., Philadelphia, PA (Nov. 1977).

Field, Charles G.; Rivkin, Steven F. The Building Code Burden. Lexington Books, Lexing ton, MA (1975).

Hemenway, David. Industrywide Voluntary Product. Standards. Bellinger Publishing Company, Cambridge, MA (1975).

International Association of Plumbing and Mechanical Officials. Uniform Solar Energy Code. Los Angeles, CA (1976 edition).

Jordan, Richard; Liu, Benjamin, eds. Application of Solar Energy for Heating and Cooling of Buildings. ASHRAE, New York, NY (1977).

Knight, H. Gary; Nyhart, J. D.; Stein, Robert E. Ocean Thermal Energy ConversionLegal, Political, and Institutional Aspects. American Society of International Law, Lexing ton Books, Lexing ton, MA (1977).

Sanderson, Richard. Codes and Code Administration: An Introduction to Building Regulations in the United States. Building Officials Conference of America, Inc., Chicago, IL (1969).

Schoen, Richard; Hirshberg, Alan S.; Weingard, Jerome M. New Energy Technologies for Buildings. Ballinger Publishing Co., Cambridge, MA (1975).

Shelton, Jay; Shapirn, Ira. Woodburner's Encyclopedia. Wood Energy Institute (1976).

Williams, Richard. Solar Energy Technology and Applications. Ann Arbor Science, Ann Arbor, MI (1977).

\section{REPORTS}

AIA Research Corporation. Early Use of Solar Energy in Buildings, A Study of Barriers and Incentives to the Widespread Use of Solar Heating and Cooling Systems. Washington, D.C., AIA Research Corporation for NSF, Washington, D.C. (Aug. 1976).

AlA Research Corporation. Solar Regulatory Provision Study. 1737 New York Avenue, Washing ton, D.C. 20006 (Feb. 1978). 
American National Standards Institute. Policy and Procedures \& Manual of Operations for Accreditation of Certification Programs. New York, NY (Aug. 1976).

American Society for Testing and Materials. Standardization Basics. Philadelphia, PA (1974).

American Wind Energy Association. The Federal Wind Program: A Proposal for FY79 Budget. DOE (Feb. 1977).

Arthur D. Little, Inc. Residential Solar Heating and Cooling Constraints and Objectives. DOE (May 1976).

Berkowitz, J. B.; Horne; R. A. Solar Energy-I! The Potential for the Solar Heating and Cooling of Buildings. Arthur D. Little, Inc., Cambridge, MA (1976).

Bottaro, Drew. The Purpose and Role of Product Standards in the Commercialization of New Energy Technologies: A Preliminary Analysis. MIT Energy Laboratory Working Paper MIT-EL-78-023WP. Cambridge, MA (Oct. 1978).

U.S. Department of Energy. Advanced Notice of Proposed Rulemaking, "Energy Perf ormance Standards for New Buildings," Titlc 10, Code of Federul Regulation Part 435, Federal Register. (Nov. 21, 1978).

- Environmental Development Plan (EDP)-Solar Agricultural and Industrial Process Heat. (Mar. 1978).

Buildings. (Mar. 1978).

- Envirunmental Development Plan (EDP)-Solar Heating and Cooling of (Mar. 1978).

- Environmental Develópmenit Plun (EDP)-Solar 'l'hermal Power Systems.

- Fnvironmental Develupinent Plan (EDP)-Wind Energy Conversion. (Mar. 1978).

- Federal Wind Energy Program-Program Summary. (Jan. 1978).

- Legal Barriers to Solar Heating and Cooling of Buildings. NTIS HCP/Ma5a8-01, UC-59a. (1978).

(Jan. 1978).

- Ocean Thermal Energy Conversion (OTEC) Program-Program Summary.

- Solar Energy-A Status Report. (June 1978).

- Solar Thermal Power Systems Program-Program Summary. (Jan. 1978). 
Dinezio, Charles J.; Stanton, P. E. Reports Relative to the Development, Administration, and Enforcement of Building and Housing Codes. Massachusetts Department of Community Affairs (Apr. 1971).

The Douglas Commission. Building the American City. Report of the National Commission on Urban Problems to the Congress and to the President of the United States (1968).

Energy Research and Development Administration. Barriers Connected with Certifying or Listing of Energy Conserving Products Used in Buildings. Prepared by Hittmann Associates, Inc. (May 1977).

- Solar Energy for Agriculture and Industrial Process Heat Program Summary. (June 1977).

- Solar Program Assessment: Environmental Factors-Wind Energy Conservation. (Mar. 1977).

- Survey of the Applications of Solar Thermal Energy Systems to Industrial Process Heat. (Jan. 1977).

Electric Power Research Institute. Solar Technology Today-Special Report, EPRI Journal. (Mar. 1978).

Energy Report. Energy Policy Project of the National Conference of State Legislature (Apr. 28, 1978).

Environmental and Resource Assessment Branch, DOE/ERDA. Solar Program Assessment: Environmental Factors, Ocean Thermal Energy Conversion. Washington, D.C. (Mar. 1977).

Fenves, Steven J.; et al. The Structure of Building Specifications. National Bureau of Standards (Sept. 1976).

Florida Solar Energy Center. Solar Energy Commercialization at the State Level: The Florida Solar Energy Water Heater Program. Prepared for FEA and the State of Florida, FSEC 76-3 (Mar. 1977).

General Electric Company. General Electric Company Survey to Define Impact of Statewide Building Codes on Solar HVAC Systems. Commercial Buildings, NTIS COO/2683-76/11, Philadelphia, PA (July 1976).

General Electric Company. Solar Heating and Cooling of Buildings, Feasibility and Planning Study, Final Report. (May 1976).

General Electric Company. Wind Energy Mission Analysis-Executive Summary. Prepared for ERDA (Feb. 1977). 
U.S. Department of Housing and Urban Development. HUD Solar Status. A special report published in cooperation with DOE (Mar. 1978).

Kaiser Committee. A Decent Home: Report of the President's Committee on Urban Housing. U.S. Government Printing Office, 0313-957 (1969).

Legal-Institutional Implications of Wind Energy Conversion Systems. Prepared by / Program of Policy Studies in Science and Technology, George Washington University, for NSF (Sept. 1977).

Mataset, Patricia; Heffner, Grayson. Certification Development, Draft, PRC Energy Analysis Co. Prepared for ,DOE (1978).

Medlar, Leon; Taylor, Samuel. Draft Interim Report for the Program to Develop a Preliminary Implementation Plan for the Federal PV Utilization Program and a Preliminary Commercialization Plan for PV's. BDM Corporation, McLean, VA (Feb. 20, 1978).

M̄eeker III, Frank O. Building Codes as Barriers to Solar Heating and Cooling of Buildings. Environmental Law Institute, Washington, D.C. (Apr. 1978).

Miller, A. S.; Thomas, G. P. Legal Barriers to Solar Heating and Cooling of Buildings. Environmental Law Institute, (Mar. 1977).

MIT Energy Laboratory. Government Support for the Commercialization of New Energy Technologies: An Analysis and Exploration of the Issues. Energy Laboratory Report, No. MIT-31 76-009. Cambridge, MA (Nov. 1976).

MI'TRE Corporation. Preliminary Wind Energy Commercialization Program. (Nov. 1976).

National Academy of Engineering. Technology Transfer and Utilization Recommendations for Redirecting the Emphasis and Correcting the Imbalance, PB-232-123. For National Science Foundation (Feb. 1974).

National Academy of Sciences, Panel on Ocean Thermal Energy Conservation, Marine Board, Assembly of Engineering. Selected Issues of the Ocean Thermal Energy Conversion Program. Washington, D.C. (1977).

National Bureau of Standards. Plan for the Development and Implementation of Standards for Solar Heating and Cooling Applications. NBSIR 78-1143A, prepared for the Office for Conservation and Solar Applications, DOE, Washington, D.C. (1978).

- State Solar Energy of 1976: A Review of Statutes Relating to Buildings. Washington, D.C., NTIS PB-273 899 (1977).

- A Survey of State Legislation Relating to Solar Energy. Washington, D.C., PB-258-235 (Apr. 1976). 
Office of Technology Assessment, U.S. Department of Energy. Application of Solar Technology to Today's Energy Needs, Draft Report. Washington, D.C.: U.S. DOE (1977). (1977). - Application of Solar Technology to Today's Energy Needs, Draft Report. - Renewable Ocean Energy Sources, Part I-OTEC. (May 1978).

Robbins, Martin; et al. Federal Incentives for Innovation. Industrial Economic Division, Denver Research Institute, University of Denver, Denver, CO. For National Science Foundation (1973).

Sandia Laboratories. Solar Total Energy Program Plan. (Aug. 1976).

Solar Energy Research Institute. A Plan for the Development of Performance Criteria and Test Methodology for Photovoltaics. Golden, CO (Jan. 1979).

- Economic Feasibility and Market Readiness of Solar Technologies-Final Draft Report, Vol. I. Golden, CO (Sept. 1978).

Solar Heating and Cooling of Buildings (SHACOB) Commercialization Report, Options and Strategies, Volume II. FEH (July 15, 1977).

TWR Systems Group. Solar Heating and Cooling of Buildings (Phase 0), Volume II. (May $31,1974)$.

\section{PERIODICAIS}

Butt, Sheldon. "News from SEIA-Update on Collector Tests and Standards." Solar Engineering Magazine. (May 1978).

Justin, B. "Performance Testing of Solar Collectors." Sun World. Vol. 2, No. 3, p. 66-71 (Aug. 1978).

Mayer, Don. "Standards for Wind Systems." AWEA Newsletter. (Feb. 1978).

"National Certification: Where Are the Standards?" Solar Engineering Magazine. (Feb. 1978).

Oddo, Sandra. "Standards and Codes." Solar Age (May 1978).

SEIA. SEIA Newsletter. Washington, D.C., p. 2 (Feb. 1978).

"Solar Standards-What's in a Label?". Solar Outlook. (Nov. 1977). 
Tennyson, George. "Test and Product Standards for WECS." (Summer 1977).

\section{PROCEEDINGS}

ASTM. Minutes of the Meetings of ASTM E-44. Philadelphia, PA (Jun. 13-15, 1978).

ERDA, Division of Solar Energy. Proceedings of the Third Workshop on Wind Energy Conversion Systems. (August 1975).

Johanson, Edward. "Institutional Barriers to WECS Growth," Third Wind Energy Workshop. (Sept. 1977).

"Research and Innovation in the Building Regulgtory Process." Proceedings of thr. First NBS/NCSBCS Jolnt Conference; Providence, RI; $9 / 21-9 / 22 / 76$ in conjunction with the Ninth Annual Meeting of NCSBCS, Inc.; NTIS PB-267-310; NBS, Washington, D.C., NBS Spec (June 1977).

The Solar Market: Proceedings of the Symposium on Competition in the Solar Energy Industry. Bureau of Competition, FTC (Symposium held Dec. 15-16, 1977).

Wilson, Robert E. Proceedings of the Second Workshop on Wind Energy Conversion Systems. "Working Group A - Standards, Testing, and Nomenclature." NSF-RA-N-75050, NASA (June 9-11, 1975) p. 369.

Wolff, Ben. Third Wind Energy Workshop. "Standards and Testing of WECS." AWEA. Edited by JBF and ERDA (Sept. 1977).

\section{CASES}

Barbier v. Connolly, 113 U.S. 27, 31 (1885).

Railroad Co. v. Husan, 95 U.S. 465, 471 (1978).

Nobel State Bank v. Haskell, 219 U.S. 104, 111 (1911).

People v. Willi, 179 N.Y. Supp. 542, 548 (N.Y. 1919).

California v. Zook, 336 U.S. 725, 728 (1949).

Heart of Atlanta Motel .v. United States, 379 U.S. 241 (1964).

McCulloch v. Maryland, 4 Wheat. 316, 436 (U.S. 1918). 


\section{STATUTES}

2 Minn. S.R. 866. Copies may be obtained from the Documents Section, 140 Centennial Bldg., St. Paul, Minn. 55155, Phone: (612) 296-2874.

Cal. Rev. Tax Code $\$ 170.52 .5$ (West Supp. 1976).

Conn. Gen. Stat. Ann., \$ 12-81 (West Supp. 1977).

Fla. Stat. Ann. $\$ 377.705$ (1)-(4) (West Supp. 1976).

1972 Heating and Air Conditioning Code for the City of Atlanta, $\$ 2401$ (Amended, February 15, 1977).

Ind. Case $\$ 6-1.1-12026$ (Supp. 1977).

Md. Code Ann. $\$ 81-12 F-5$ (Supp. 1976).

Mass. Ann. Laws, ch. 59, $\$ 59,4145$, (Michie/Law co-op 1978).

Minnesota Stat. Ann. $\$ 116$ H.127 (1977).

N.C. Gen. Stat. $\$ 105-151.2$ (Supp. 1977).

1977, N.M. Laws, Vol. III, Ch. 347.

N.M.S.A. 67-35-13F (1953).

New Mexico Solar Heating and Cooling Regulations, S.T.C. Regulations, 11.3(A):8.

Nevada, Ch. 598, Làws of 1477.

Or. Rev. Stat., $\$ 469.175$ (Supp. 1977).

Wash. Rev. Code Ann. $\$ 84.36 .410$ (Supp. 1977).

Wisc. Stat., $\$ 71.09(12)(1977)$.

15 U.S.C., $\$ 2301$ et seg. (Supp. 1977).

15 U.S.C. $\$ 2301(6)$ (Supp. 1977). 
TR-095

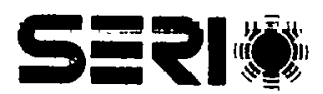




\section{APPENDIX A}

\section{STATE AND LOCAL ISSUES}

This appendix examines state and local issues concerning standards, certification programs, and building codes. The purpose is twofold: first, to assist state and local governments in formulating future programs; second, to assist the Department of Energy (DOE) in structuring a national program that will recognize and accommodate interstate diversity and at the same time eliminate the confusion created by inconsistent state and local programs.

To this end, this appendix is divided into two sections: State and Local Action: Standards for Solar Systems, which discusses the development, promulgation, and implementation of standards through such actions as certification, tax-incentive, and warranty programs; and State and Local Action: Building Codes for Solar Systems, which discusses the implementation of standards through building codes. 


\section{STATE AND LOCAL ACTION: STANDARDS FOR SOLAR SYSTEMS}

\section{Introduction}

This section examines state and local standard setting, certification, warranty, and associated programs for solar systems. As various solar technologies reach a stage of market readiness, state policymakers are formulating ways to stimulate the growth of a healthy solar industry infrastructure able to sustain consumer confidence. Appropriate strategies are difficult to formulate because of the inherent tension between the two interest groups directly affected: industry and consumers. To provide encouragement to the industry, government intervention is normally kept at a minimum; to provide protection to the consumer, the state traditionally intervenes to a greater degree. Thus in establishing government policies the importance of striking a balance between these competing interests cannot be overstated.

The tension between industry encouragement and consumer protection is highlighted in the solar context because new solar technology applications are being introduced at a pace accelerated by both industry and the Federal government. Regulations must be carefully thought out to avoid excluding innovative processes and systems from the marketplace, yet simultaneously preventing the introduction of unsafe or unreliable processes and systems.

To date efforts to establish a national regulatory scheme that will accommodate the competing interest groups are still provisional. As a result state policymakers have begun to fill the solar regulatory vacuum. A perusal of state activities indicates a trend towards the enactment of legislation either directly or indirectly affecting solar system quality [1]. Few states have enacted laws which expressly require the development of standards for solar systems (California, Connecticut, Florida, Minnesota, New Mexico, and Nevada). Only two states, Florida and California, have actually adopted regulatory schemes whereby standards are established, laboratories are accredited, and solar equipment is tested. A significant number of states (at least thirty) have enacted property or income tax incentives, and the guidelines used by state and local officials to determine eligibility for the tax measures are essentially "de facto" standards to regulate the quality of solar systems even in the absence of legislatively mandated standardsetting. Solar advocates criticize the proliferation of state regulatory activity because of the confusion it creates for the solar industry. As one industry member stated:

Multiple and conflicting product performance criteria and warranty requirements are either being imposed or recommended by just about every local, state, and federal government agency, industry association, trade association, and so forth. This makes it virtually imposzible for manufac. turers to forecast the ground rules and eventual outcome of their solar program [2].

It is noteworthy that regulatory activity by the various institutions involved in the setting of standards lacks effective coordination necessary to produce a unified scheme. The absence of a set of consistent national standards does not justify divergent regulations, but it does explain state and local efforts to fill the regulatory vacuum.

States have traditionally been responsible for protecting the public health, safety, morals, and general welfare within their respective territories through the exercise of police powers [3]. The basic limitation on state action is that states have no power to 
impede, burden, or in any way control the operation of the laws enacted by the Federal government pursuant to proper Federal authority [4].

Contemporary constitutional doctrine protects the flow of interstate commerce by allowing Congress to regulate practically all aspects of economic activity that affect interstate commerce [5]. It follows that Congress is legally authorized to establish a national regulatory policy regarding the production and distribution of solar systems. However, federal solar legislation enacted to date does not expressly address the regulation of commercial solar activity. Until Congress acts, state regulation of local commercial activity in the solar industry may be legally defensible because of its potential impact on public health and safety. The validity of state regulation over commerce where Congress is silent ultimately depends on "whether the state interest is outweighed by a national interest in the unhampered operation of interstate commerce" [6].

Arguments are available for both sides: essentially, nonuniform state and local regulations impede the commercialization of solar energy systems to the extent that solar equipment manufacturers, distributors, and vendors must satisfy more than one set of regulatory demands. On the other hand, solar hot water and space heating systems, although functionally ready for marketing, are consumer products carrying potential social costs (e.g., fraudulent claims regarding solar system performance). The public welfare is served by avoiding consumer dissatisfaction with solar energy technologies now, through preventive state regulations, rather than relying on future Federal regulatory policies to remedy any dissatisfaction after the fact.

The section discusses the major problems created by state solar legislation and regulatory schemes as they relate to standards and the uses of standards: lack of consistency (interstate and intrastate) and uncertainty as to which equipment and systems are defined as a solar technology subject to state statutes. Various state laws and programs are highlighted to illustrate the problems. State efforts to prevent or remedy the. problems are also mentioned. The testing and certification programs developed in Florida and California are discussed in some detail to provide the reader with some insight into the regulatory process.

\section{Slundürưd Betting}

To date, most state legislatures that have chosen to control commercial activity in the solar industry have enacted laws of two general types: (1) laws that affect the manufacture or sale of solar systems, and (2) laws that lessen tax burdens on the ultimate users of solar systems. In both cases the legislation expressly or implicitly calls for the development of guidelines against which the vendor's, manufacturer's, or taxpayer's system may be judged. Legislatively mandated standards development is also tied to some state tax incentives, although most tax incentives call for discretionary approval of applicunts' systéms.

Regardless of whether a particular law expressly directs a state agency to develop standards, or in general terms requires agency approval before an applicant may receive the tax benefits allowable by law, the net outcome is essentially the same: standards are set. State and local officials charged with approval powers have a responsibility to adopt proccdures for reviewing applications, even in the absence of legislatively mandated standards development. 
In formulating procedures, agencies must address at least two issues: (1) how "solar system" will be defined and (2) how solar systems will be judged. When one considers that a "standard" is used to define, measure, specify, classify, or guide the use of a product, system, or service, it becomes apparent that the issues addressed by state and local officials are the precise considerations relevant to conventional standards writing. Therefore, the procedures ultimately adopted by the responsible officials are, in substance and in effect, standards.

\section{Standard Definitions}

Many state laws do not expressly define which solar technologies or applications are within the scope of the legislation. Tax incentives that apply to "solar heating or cooling systems ${ }^{t i}$ [7] are ambiguous. It may be argued by some that the legislation was not intended to include passive systems. Although a means of heating or cooling buildings, passive systems are distinguishable from active systems by their use of the structural elements of buildings rather than mechanical components to provide for heating or cooling. In the absence of express reference to passive systems, officials charged with processing taxpayers' applications may use their discretion to decide whether passive systems qualify for the incentive.

If, pursuant to the law, a state agency is required to prescribe regulations to carry out the purposes of the law, confusions in definition may be solved before the law is actually implemented. Especially troublesome is the difference between passive solar systems and conservation measures. For example, an income tax incentive passed in California allows taxpayers to deduct from the income tax owed the costs of "solar energy devices designed to produce heat or electricity" [8]: Pursuant to the law, regulations passed by the Franchise Tax Board elaborated on the legislative definition: '"Solar Energy Device' means equipment which uses solar energy to heat, cool, or produce electricity . . . . Insulation, double paned windows, shades, weather stripping and other similar 'passive' items DO NOT QÜALIFY FOR THE CREDIT" [9].

In general, a property tax incentive differs from an income tax incentive in that the latter is enforced uniformly throughout the state, whereas the former is traditionally subject to local control. Property tax incentives are potentially more problematic because, as a practical matter, local officials charged with assessing property values of ten lack the time and resources to resolve ambiguities in definition before the law is actually enforced. In Massachusetts, the property tax exemption requires local tax assessors to deduct the value of solar or wind systems from the home's taxable value [10]. Taxpayers using passive systems have reported difficulties in receiving the exemption, despite the State Energy Policy Office's desire to apply the tax incentive to passive systems. As a result, a seminar is being planned to educate local assessors [11]. Additionally, Massachusetts is considering adoption of the New Mexico solar heating and cooling regulations which offer definitive assessment guidelines:

"Passive" solar heating systems designate those systems which utilize the architecture of a building to maximize solar heat gains during the cold seasons and minimize heat losses, which provide thermal storage within the building, but does not include storage devices or delivery systems which are also utilized for other means of heating and/or cooling including backup systems. [12] 
Standard definitions for solar equipment are beginning to appear in local building codes. For example, the Denver Unif orm Building Code, Chapter 52, Heating and Ventilating, defines "solar collector" and "solar collector system." The Solar Heater Standards Code for Pinellas County, Fla., also contains definitions. "Solar Heater," for example, is defined as "any unit designed to circulate a liquid through metal or plastic piping or enclosed grillage for the purpose of heating the liquid" [13].

Unlike some of the vague legislative definitions noted above, the specific language used in the Pinellas Code exemplifies a problem at the other extreme: according to its definition of solar heater, a unit designed to circulate air through piping for the purpose of heating liquid is not a solar heater. Given the accepted usage of either water or air as the circulating medium in a collector, the prescriptive standard contained in Pinellas' Code is a perfect illustration of how a standard might exclude nonconforming, yet otherwise acceptable, products from the market.

\section{Consistent Standards}

A state's legislative mandate to develop standards can facilitate interstate uniformity by referencing existing national or federal standards. The potential flaw with such an approach is that to date most of the national and federal standards relevant to solar systems are provisional, having been developed for use on a limited basis. State or local use of these standards before they are fully developed may have negative consequences (e.g., stultifying innovation).

A law passed in Minnesota required the State Building Code Division, with consultation by the Minnesota Energy Agency, to promulgate quality and performance standards for solar systems. The standards are required to be in "reasonable conformance" with the interim standards developed by NASA and the National Bureau of Standards. New standards or -modifications may be developed subsequently as new technology and materials become available. Manufacturers or retailers of solar energy systems are compelled by statute to disclose to potential purchasers the extent to which their systems meet the standards [14].

Notwithstanding the potential problems associated with adoption of any provisional standards, the Minnesota legislation minimizes divergent regulations yet at the same time allows for legitimate regional differences as well as updating. Minnesota's decision to promulgate standards in reasonable conformance with national and federal standards shows a sensitivity to the needs of interstate commerce. Out-of-state manufacturers and retailers of solar systems will not be prevented or discouraged from transacting sales with Minnesota citizens because thay can be confident that their merchandise will not be judged by an unusual set of standards.

State tax incentives that do not expressly require standards to be promulgated can facilitate interstate uniformity by requiring an applicant's system to meet federal or national standards. In Washington, for example, only those solar energy systems that meet HUD's Minimum Property Standards (including any amendments), plus any additional criteria approved by the Department of Revenue, are exempted from homeowners' property taxation [15].

A similar North Carolina law includes a reference to federal performance criteria for an income tax credit for solar hot water, heating, or cooling systems [16]. Neither state requires standards to be developed, yet both afford state officials the flexibility to resolve problems that might arise as a result of adoption of provisional federal standards. 
Property tax incentives without standards threaten intrastate as well as interstate unif ormity. Legislation such as Maryland's, which allows the county or city to determine which solar heating or cooling units are eligible for a local property tax credit [17], may lead to conflicting standards within the state.

Because real estate is a sensitive local issue, a compromise legislative scheme was developed in Connecticut [18]. The legislation required local property tax exemption measures to meet standards established by the state commissioner of planning and energy policy, but local adoption of the incentive is optional. Intrastate uniformity is thereby assured, yet local control over property matters is maintained to some degree.

It is important to recoginze that solar hot water, space heating, and cooling systems, however defined, are simply innovative alternatives to conventionally fueled heating and cooling systems. As such, there are provisions in building codes that directly apply to solar installations (e.g., piping, material strength, and electrical requirements) which should receive primary consideration in any standard-setting effort.

The Florida Solar Energy Center (FSEC) was required by statute to develop and promulgate standards for solar energy systems manufactured or sold in Florida [19]. In formulating design and performance standards for solar water heating systems, the FSEC considered applicable building codes: Standard Building Code, National Electric Code, Unif orm Mechanical Code, and Southern Standard Plumbing Code. The Florida solar hot water standards were designed to mesh with relevant electrical, mechanical, and structural provisions in these codes. Ultimately, the center hopes that a uniform state building code will be adopted that will supercede all other building codes and include provisions for solar installations [13, note 13 at $32-34]$.

\section{The Implementation of Standards: Testing, Certification and Labeling}

To date, excepting the use of standard definitions to determine eligibility for tax incentives, few states have begun to enforce their respective programs. The following list provides an overview of the enforcement options adopted or considered by various states:

Voluntary participation:

- qualifying equipment may display label (Florida).[19];

- a list of qualifying equipment will be publicly distributed (FSEC report suggests as an alternative to the labeling method) [13, note 3 at 104].

Mandatory participation:

- equipment sold or installed must bear label, certification, or warranty (Nevada and Florida af ter January 1, 1980) [19 $\$ 377.705(4)(d)]$;

- equipment ineligible for tax incentive without label, certification, or warranty (California [8], New Mexico [20], Oregon [21], and Wisconsin [22]);

- manufacturer must make full disclosure: inform potential purchasers regarding system performance, proper installation, warranty details, necessary maintenance, etc. (Minnesota [14]). 


\section{Testing}

An integral part of each enforcement option listed is the testing of solar equipment. To date only Florida and Calif ornia have state-approved testing facilities and procedures in place, al though there are other laboratories equipped to test solar collectors [23].

By statute, the FSEC is the present test station in Florida [19]. Additionally, private laboratories may be accredited upon a showing of laboratory independence (i.e., nonaffiliation with manufacturers, retailers, or distributors of solar producers) and ability to perform the tests developed by the FSEC accurately and consistently.

In contrast the California Energy Commission (CEC) is not equipped to perform testing. Instead, the CEC has developed and adopted a program for the accreditation of testing laboratories for solar components and systems [24]. The criteria prescribed by the CEC for accrediting test stations are similar to those used by the FSEC: laboratory independence and ability to perform the testing. To date, six laboratories have been accredited by the CEC.

The test procedures developed in Florida and California are limited to the testing of flatplate solar collectors for thermal performance, durability/reliability, and safety features. (Methods of testing entire solar hot water systems are currently being developed by the FSEC and the CEC.) In each state, the testing was designed to be compatible with existing national standards. However, Florida's thermal performance test is designed to estimate Btu output when the collector is operated at different inlet fluid temperatures for a standard day in Florida. Although "TIPSE" (Testing and Inspection Program for Solar Equipment), the program developed in California, was designed to mesh with Florida's (and DOE's) collector testing, the tests are not identical.

To promote the flow of interstate commerce, Florida adopted a reciprocity policy whereby the FSEC will accept results of testing done elsewhere if the tests were conducted according to criteria established by the FSEC and if the testing center has no vested interest in the manufacture, sale, or distribution of solar products. The latter condition is rational for obvious reasons; the former, however, should be more flexible to allow for recognition of testing done in reasonable conformity with FSEC criteria. Otherwise the effort to facilitate interstate commerce through reciprocity may well be an empty gesture.

California's reciprocity provision eliminates the flaw noted in Florida's policy. California will accept results of previous testing if the sample collector was tested under the HUD Hot Water initiative or the FSEC test procedure, provided that the test was performed by an accredited laboratory and the laboratory certifies that the tests were performed on a random sample.

\section{Certification and Labeling}

Although California and Florida have adopted methods of testing solar collectors that are similar in many respects, the ways each state stimulates participation in the testing program and the ways each state uses the test results are quite different.

Participation in California's testing program is presently voluntary. If a manufacturer's sample collector (randomly selected by the CEC) passes the CEC test procedures, the collector model may bear a label certifying that it meets CEC standards. Securing the 
label gives the particular model an obvious advantage-consumers are typically attracted to certified products, providing they have confidence in the certifying body.

The CEC held a public hearing in May of 1978 to allow for input from various interest groups on the issue of typing collector certification into a tax credit [25]. Consumer advocates were generally in favor of the tie-in. They argued that requiring certification of collectors for tax credit eligibility would (1) promote consumer and homebuilder confidence in solar equipment; (2) cause more manufacturers to participate in the testing and therefore provide the CEC and the public with reliable information on equipment characteristics; and (3) increase the quality of equipment because manufacturers will produce equipment to conform with CEC test methods.

Solar industry representatives and the California Department of Business and Transportation generally opposed the tie-in. They argued that: (1) to tie "TIPSE" into a tax credit is to mandate an unproven testing and certification program-the mere testing of collectors may not be an adequate basis for qualifying an entire system (2) because the law requires distinct models to undergo separate tests, the high costs of testing will force smaller firms to choose one collector model for marketing (if they are able to afford the testing costs at all); the net result will be the exclusion of certain collectors from the market and ultimately premature standardization; and (3) small manufacturers require individual guidance from the $C E C$ to complete paperwork and other procedures associated with TIPSE; as a result of CEC staff limitations, small firms may have serious difficulty competing with large manufacturers.

As a result of the hearing, a voluntary certification program was adopted, and the final decision on the tie-in was deferred. In the interim, the CEC will have additional time to evaluate "TIPSE", premature standardization will be avoided, and the legislature will consider appropriating funds to subsidize testing costs. The decision reached by the CEC avoids some of the problems associated with prematurely mandated certification.

The certification plan developed in Florida is voluntary and is not officially tied into any incentive or mandatory regulation. However, the statutes were recently amended to require certification of collectors, sold after January 1, 1980. Currently, manufacturers are authorized to attach a label of certification to each collector model tested that meets the minimum standards required by the FSEC. This creates an incentive to participate in the testing program because, as noted, consumers are typically attracted to certified products. Notwithstanding the marketing advantage gained by securing a label, interstate uniformity and commercial activity are not directly impeded because out-of-state manufacturers are free to market uncertified equipment (until January 1, 1980).

Florida's early effort to provide consumer information is reminiscent of the attempt to promote solar hot water systems in Florida in the 1950s, an effort which ultimately failed because of low-cost gas alternatives and highly publicized isolated system failures. Against this background, Florida legislators deemed it necessary to guard against a historical repeat by providing consumers with market information at the earliest possible date.

\section{Alternatives to Certification and Labeling: Listing and Warranties}

The FSEC was required by statute to adopt a certification and labeling program for solar equipment [19]. However, in developing the program the center identified alternative plans that might be followed by other states. 
"Listing" is an alternative that has received attention not only in Florida but also in other states such as California. The rationale behind listing is that the public should have access to information on solar energy equipment costs and capabilities that is not couched in technical language.

Essentially, a listing program would probably involve the same standard setting, methods of testing, laboratory accreditation, and equipment evaluation associated with certification programs. However, instead of using a system in which a third-party independent testing facility certifies that the product or system has been tested in accordance with a reference standard, each collector's performance could be rated in layperson's terms, and lists of such ratings would be available to the public.

Warranties are a means of protecting the consumer that may be used as an alternative to or in conjunction with certification or listing programs. The Magnuson-Moss Warranty Act of 1975 defines written warranty as:

- any written affirmation of fact or written promise made in connection with a sale of a consumer product by a supplier to a buyer which relates to the nature of the material or workmanship and affirms or promises that such material or workmanship is defect-free or will meet a specified level of performance over a specified period of time; or

- any undertaking in writing in connection with the sale by a supplier of a consumer product to refund, repair, replace or take other remedial action with respect to such product in the event that such product fails to meet the specifications set forth in the undertaking; which written affirmation, promise, or undertaking becomes part of the basis of the bargain between a supplier and a buyer for purposes other than resale of such product [26].

The HUD Hot Water Demonstration Program was the first program to require a manufacturer's warranty on the major parts of any solar system. [The ten northeast states and Florida, participating in the HUD demonstration program under the direction of the Massachusetts State Solar Action office, developed minimum warranty standards. The guidelines developed include a five-year warranty against defects and manufactured materials and also define the responsibility for shipping defective warranted parts back to the factory and paying the labor costs.

California is now mandating a one-year warranty on parts and labor and a three-year manufacturer's warranty on major components as a prerequisite to eligibility for its tax credit. Additionally, the CEC and various industry associations are developing warranty programs to provide financial backing to firms offering solar equipment or system warranties.

An idea under consideration is to require manufacturers, distributors, and installers Eceking to participate in the program to submit their systems or devices to a certification process. Once qualified, a member would be charged a premium (percentage of sales), and the funds collected would be placed in a common pool. Firms that became insolvent or breached their warranty obligations would receive financial assistance from the warranty assurance pool [27].

Warranty pools may be the solution to the financial burden that mandated warranties place on small solar businesses. If so, can, will, or should the solar industry be primarily responsible for developing the pool or is government involvement necessary? There is no 
easy answer to this question, but industry's negative reaction to the government's standard setting, testing, and certification activities makes it likely that industry members will make a concerted effort to preempt official intervention by developing a workable approach to warranties.

\section{Conclusion}

Solar policymakers at all government levels must be sensitive to the tension between healthy industry growth and consumer protection, particularly now when new solar technology applications are rapidly being introduced. A recurring fear voiced by industry members is that laws requiring standards to be set and enforced now will prevent industry growth. Consumers, on the other hand, are hesitant about investing money in solar products without some assurance of the product's quality, reliability, and performance capabilities.

Notwithstanding the complexity of the issues involved in considering government involvement in the solar energy marketing process, questions can be raised as to whether warranty programs provide a substitute for certification programs.

Ongoing efforts to establish a national approach to solar product quality are apparently based on the assumption that enforcement of standards is necessary. State and local policymakers seem to be proceeding on the same assumption. Thus until a national program is developed and implemented, the proliferation of state interim measures is predictable.

There are no easy solutions that will satisfy the concerns and neers of hoth interest groups-government regulation is not a panacea. In formulating solar energy policies, it is important and instructive to remember that the ultimate policy goal is the commercialization of useful solar energy technology applications. Tn that end, state tax incentives contingent upon certification seem to offer an approach that encourages the industry to produce quality products and alleviates the financial burden on consumers. However, tax measures linked to certification may impede, albeit indirectly, the introduction of innovative products and, potentially, create a burden on interstate commerce. The same consequences are predictable for voluntary participation in certification programs, required disclosure statements, mandated warranties, and product/manufacturer listings.

Perhaps the best policy would stimulate the solar industry with a "carrot" rather than a "stick." For example, instituting a system of government awards or bonuses for individuals and firms making significant contributions might be one approach, although the potential effects of an award system are not likely to be as far-reaching as standards enforcement. The possibility is mentioned simply to indicate that there are alternatives to regulation, and solar policymakers at all levels will promote general welfare by searching for those alternatives rather than assuming that traditional forms of government intervention are the best ways to promote the commercialization of solar energy. 


\section{STATE AND LOCAL ACTION: BUILDING CODES FOR SOLAR SYSTEMS}

\section{Introduction}

This section surveys state and local action regarding building codes and solar energy systems. Its purpose is threefold: (1) to provide information about recent activity; (2) to elucidate some of the problems facing states and localities that might be solved by federal action, and (3) to analyze some of the pros and cons of various approaches reflected in recent activity as a guide to officials and policymakers at the state and local levels. Although the section will focus on systems for heating and cooling buildings, it should be noted that other solar technologies, such as wind energy conversion systems [28], already face building code issues, and the diffusion of other technologies such as photovoltaics may be expected to raise code-related issues in the future.

\section{Building Codes}

Building codes are of ten cited as a major hindrance to the utilization of new technology in the building industry [29]. On the one hand, excessively restrictive provisions interfere with important new developments; on the other, lack of provision for new methods and materials has been criticized as leaving too much to the discretion of individual officials. Perhaps the most frequent complaint about codes is their lack of uniformity. In 1968 the Douglas Commission reported that "building code jurisdictions are thousands of tiny little kingdoms, each going its own way; what goes in one town won't go in another-and for no good reason" [30]. In the ten years since the commission issued its report, much has happened to improve the situation, such as the trend toward adoption of stateside building codes and the formation of the Council of American Building Officials (CABO) to coordinate the activities of the various model code groups. However, the struggle to modernize the building industry and to streamline the code system is far from over.

Several studies have dealt with the problems faced under existing building and mechanical codes by systems utilizing solar energy [31,32]. Therefore, no attempt will be made here to cover the subject in any depth. The complaints of ten voiced about building codes in general can apply to provisions for solar energy applications. There are specific code provisions that may inhibit the use of solar systems and also significant areas where the codes are silent, leaving building officials with considerable discretion, such as the right to insist on expensive testing.

The increasing demand for solar methods for heating and cooling buildings and for supplying domestic hot water is creating an accelerating demand on building of ficials to evaluate the safety of solar systems. There is a growing concern among officials, and among the public, that the profit potential in manufacturing solar energy systems will attract firms and individuals interested in quick profits at the expense of safety and quality. As a result, there is some pressure on states and localities to enact building code provisions relating to solar devices. To date only a few states, cities, and counties have responded to this pressure, but the trend is clearly in the direction of more state and local action. It is useful to look at some of the actions taken to determine to what extent they solve existing problems and to what extent they merely create new problems.

This section evaluates a selected sample of state and local activities. Where appropriate, the following features of each activity are discussed: (1) what agency has 
responsibility for developing solar code provisions; (2) where that agency derives its authority; (3) the goals of the agency's actions; (4) what regulatory method or approach has been adopted; (5) how the regulations are to be enforced; (6) whether the needs of enforcement officers, such as a need for additional training, are being addressed; and (7) what advantages and/or problems seem to arise from the activity.

\section{Model Codes}

Before proceeding to specific state and local actions, some discussion of model codes is in order. Many of the nation's building codes are related in some way to one of the national model code groups. Some of the claimed advantages of model codes are that they promote uniformity, provide a forum for discussion of innovation, and remuin technically current through periodic review. Some of the utility of model codes is lost through local amendment and through regional vested interests, expressing local unwillingness to go along with changes in the status quo as accepted at the national level 「33].

The only model solar code at present is the Uniform Solar Energy Code published by the International Association of Plumbing and Mechanical Officials (IAPMO). IAPMO is also responsible for the Uniform Plumbing Code, which is used extensively in the western United States. The IAPMO Solar Code has been widely criticized. One commentator asserts that "this particular version should not be adopted at all. There are too muriy errors, omissions, and lack of particular standards .... it is not keyed to the evolving federal standards and developing private-sector standards for solar heating and cooling systems, but goes off on a tangent of its own . . . this code is seriously flawed" [32].

Flawed or not, the Uniform Solar Energy Code is one of the principul options available to states, counties, and municipalities facing the solar issue. One state and a number of local jurisdictions have already adopted it.

As a result of a study sponsored by the Department of Energy and undertaken by the National Bureau of Standards, a recommendation has been made that a Model Solar Code be developed under Federal government auspices before the end of 1978 [34]. A proposal to develop such a code has come from the Council of American Building Officials. That a model code would be welcome, at least in some jurisdictions, is evident from the state and local profiles which follow.

\section{Activity: Four Profiles}

\section{Minnesota}

Legislation passed in 1977 [14] directs the Building Code Division of the Department of Administration, in consultation with the Energy Agency, to promulgate "rules . . . concerning yuulity and performance standard" for solar energy systems. These standards are to be in "reasonable conformance" with National Bureau of Standards and NASA Interim Performance Criteria and are to be modified as new technology and materials become available along with the development and promulgation of new standards. A second paragraph adds that retailers and manufacturers of such systems shall disclose to potential purchasers the extent to which the system meets or exceeds such standards. 
At the outset a terminology problem should be noted. Administrative rules, building codes, and standards for performance and quality are of ten considered three separate things, but in the Minnesota legislation all three terms are listed interchangeably. As a result, the legislation and subsequent actions by the Building Code Division are difficult to characterize. Pursuant to the statutory authority, rules have now been promulgated [35]. The rules include design criteria for solar energy systems and subsystems, and they incorporate performance quality standards by reference. The definitions section delineates the scope of the rules. A solar energy system is defined as an "assembly of subsystems and components which is designed to convert solar energy into thermal energy." These rules and the standards they incorporate are not a building code in the usual sense because builders are not obligated to conform with them. The only requirement is that manufacturers disclose the extent of conformity to the standards. Enforcement is in the hands of local building officials who are not to issue permits for installation until the seller has submitted a completed Disclosure Statement Form. The official is not required to determine the accuracy of the seller's disclosures or the extent to which the system meets the standards, but sellers are liable for knowingly submitting false information.

Minnesota's approach can be seen as a compromise of the conflicting demands of providing for the safety, health, and welfare of the public and allowing the development of the solar industry without excessive government regulation. On the one hand, consumers are provided with information about the systems they are considering; on the other hand, the industry is not saddled with meeting standards that might be premature. The standards themselves, as authorized in the statute, are open to change as technology develops and are substantially identical to federal requirements, and therefore do not impose a special burden on manufacturers through lack of interstate uniformity.

It should be noted that no provision is made for special education for building inspectors. Also, like any compromise, the Minnesota approach is open to criticism from both sides. From the point of view of public health, safety, and welfare, the non-obligatory quality of the standards negates the protection afforded by an actual code. It is hoped that building inspectors will use these standards as a guide in making decisions about solar installations. If not, the solar industry will still face the excessive burdens possible under existing codes. In summary, on the surface the Minnesota approach looks like a building code but falls short of actually being one. A solar code provision should serve one purpose: to protect the public health, safety, and welfare. This purpose is not entirely served by the Minnesota approach.

\section{New Mexico}

New Mexico, in July 1977, became the first state to adopt the IAPMO Code. There was no specific enabling legislation, but the Construction Industries Division of the State Department of Commerce and Industry has the authority to adopt statewide codes and minimum standards [36]. A few amendments were made to the code, including changing some definitions and adding provisions for licensing of installers. The primary reason for adoption of the code appears to have been a fear of "fly-by-night" operators entering the solar business without adequate experience or commitment to quality. The code was attractive because it provided at least some formal requirements as to installation and materials, and it provided a base onto which licensing of contractors could be grafted. Enforcement of the code is by local of ficials. No solar training program for of ficials is presently in operation. 
The advantage of New Mexico's action is the control it gives the state over who is involved in the solar installation industry. The disadvantages are all the problems in the code itself. Its provisions are of ten so vague as to give no effective guidance to the official administering it, and its lack of coordination with national standards can lead to a lack of uniformity in requirements that could hinder the industry.

\section{California}

California considered the IAPMO code but rejected it in favor of a proposal by the California Building Officials (CALBO). CALBO's program, which is now nearing completion, includes an analysis of the current statewide codes (primarily the Uniform Building Code), with the intention of identifying the sections that could significantly affect solar installation and making suggestions for modifying any core provisions that might inhibit approval of solar systems. Based on this analysis, CALBO will develop a systematic approach by which local officials can evaluate applications for solar systems. It is CALBO's stated intention to "provide local governments with a positive approach to solar installation and to decrease and eliminate inappropriate rejections of proposed systems." At the same time another project is underway in California to develop training programs for building officials.

The following aspects of the California program are unique:

(1) 'Ihere is a clear legislative mandate to do something, without specifying what.

(2) Authority is given directly to the State Energy Commission.

(3) Promotion of solar energy is given explicit emphasia cqual to or greater than that given to consumer protection.

(4) The approach is through the existiıg building coded rather than separate rules or u code.

(5) The needs of the individual building official are being addressed.

California's program is unique also in that it provides a statewide solution to a national problem. It is unlikely that other states would be willing or able to underwrite ventures as ambitious as those undertaken in California. Even if every state were to follow California's lead, there is no gualantee of uniform results, and industry might be burdened by conflicting regulations.

\section{Oregon}

Like New Mexico, Oregon has a statewide mandatory building code and no specific legislation concerning a solar code. The Building Code Division of the State Department of Commerce has been conducting extensive hearings and gathering information on promulgating a solar code. Originally, the IAPMO code was considered, but the storm of criticism it attracted at public hearings led state officials to reconsider their stance. They are currently in a quandary, attempting to evaluate the relative merits of adopting the IAPMO code with substantial revisions, adopting an entirely different solar code, or doing nothing. 
Pressure from the public and from local building officials is mounting. There is a fear of fraudulent operators in the solar business and the number of applications for solar installations is continually increasing. On the other hand, state officials feel there is no existing adequate code. Writing their own code would be expensive. How Oregon will solve its problem remains to be seen, but Oregon is of interest because all states face the same difficulty. There is a desire to protect the public without inhibiting solar industry growth and a second tension between the need to take action soon and the premature quality of existing standards and codes.

\section{Local Activity: Three Profiles}

\section{A. Pinellas County, Florida}

One of the earliest solar codes is the Solar Heater Standards code for Hot Water Heaters adopted by Pinellas County in 1975 [13]. Authority for the code comes from state statutes, which permit localities to adopt safety codes to preserve the safety, health, and welfare of their constituencies. The code regulates design and materials used in solar heaters and specifies who may install particular types of equipment. In the background to this code are decades of unfortunate experience in Florida with solar water heaters. When solar technology became popular again in the $70 \mathrm{~s}$, there were a few incidents involving unscrupulous operators that revived the old fears.

The code has serious flaws and could inhibit solar development. Some of these problems are discussed in Solar Energy Commercialization at the State Level [13]:

... the code specifies that collector casings shall be of metal or treated wood. The obvious question: Why not fiberglass or plastic, or other materials which may prove suitable.

The code requires that engineering drawings of a solar water heater be submitted for approval to the county building officials who may call for an 'in-factory inspection to assure the quality control of the manufacture of the specific unit.'

Were such a regulation adopted by other countries, cities, and towns, one can visualize literally hundreds of building officials inspecting solar manufacturers, and the manufacturers deluged with requests for engineering drawings.

Clearly, officials in Pinellas County gave first priority to protecting the public but less thought to the development of the solar industry.

\section{Atlanta, Georgia}

In early 1977 Atlanta amended its Heating and Air Conditioning Code to add provisions for "solar energy utilization for heating, ventilating and air conditioning systems" [37]. This ordinance has serious problems. For example, solar system designs are to conform to "ASHR AE 1974, Applications, Chapter 59." This provision not only fails to reference a particular standard but freezes the regulation at ASHRAE's standards in 1974 with no room for change short of a new ordinance. Perhaps the most important provision is one 
that states that solar systems shall be considered auxiliary or bonus energy, while primary heating, ventilating, or air conditioning systems using conventional fuels shall be required. This goes beyond requiring a backup system and forces the builder to install a system of the same capacity that would be used if no solar system were installed at all. Such a requirement might not only considerably increase the price of a solar heated building, but also discourage solar installation.

The vagueness of the ordinance is typified by its exempting from severul requirements collectors and systems which are "experimental." The building official determines what systems are experimental, but the ordinance does not give the criteria on which such decisions are to be made. The intention behind the exemption is clear: to permit solar development despite the otherwise restrictive ordinance. It is difficult to see how this or any of the ordinance's other purposes can be accomplished while the ordinance remuins in its present form.

\section{Los Angeles, Califomia}

Both the City and the County of Los Angeles have adopted the IAPMO code. The population affected by the Los Angeles code is potentially much greater than that of the entire state of New Mexico. In an urban and suburban environment where a large building department exists with a substantial technical staff, it is possible that enforcement of the code is much more immediate than in a largely rural jurisdiction such as New Mexico. It would be useful but outside the scope of this paper to obtain hard data as to problems which arise in applying the code and how difficulties are resolved, both for Ins Angeles and for New Mexico. Ultimately, the issue focuses on the skill, sensitivity to solar energy, and openmindedness of the individual official.

\section{Conclusions}

Although the sample of jurisdictions covered in this paper is limited, their actions represent a broad range of approaches. One issue which emerges is the tension between the need for action and the advisability of avoiding premature activity. Thoughtless regulation could hamper the industry by imposing excessive restrictions. The variety of approaches in itself suggests the problem of nonuniformity of codes, which cuuld plevent manufacturers from distributing over a wide geographical area. A consistent, nationally recognized set of model solar code provisions would meet the demand for action and promote a greater degree of uniformity. Another issue is the tension between the degree of regulation necessary for consumer protection and promotion of the industry. On an institutional level, it appears that states are taking a mure active role than localities in encouraging the uke of sular technology; contrast, for example, the legislation in Minnesota and California with the ordinances in Pinellas County and Atlanta. Other institutional issues are whether the legislature ought to mandate action as compared to leaving regulation to existing agencies' own initiatives and the roles of various agencies, particularly building code divisions and energy agencies, in promulgating standards and codes. It seems that input from legislutures and participation by encrgy agencies tend to encourage the solar industry, whereas building officials are more likely to be concerned with protecting the public. It is logical that state legislators might be concerned with encouraging the solar industry to locate in the state, bringing jobs and taxes, while a local building official is more likely to focus on a narrow professional task ensuring safe, dependable construction to the public. 
Ultimately, it is the individual building official upon whom much depends, whether under existing codes or model solar codes. Perhaps the most important service that could be provided to the public and to the solar industry would be programs to educate of ficials about solar systems.

A solar education program focused on solar technology could have the dual purposes of providing education about materials and design in solar systems and information about the importance of and potential for alternative energy forms. Such programs could occur on local, state, or national levels and could be sponsored by industry, government, or both. For further discussion on this topic see Section 6 on a Proposed Building Code Policy. However, the probable cost of such programs and the importance of reaching all, not just some, officials indicate the need for involvement by the Federal government.

\section{CONCLUSIONS TO AFPENDIX A}

The lack of a consistent set of national standards for use by states and localities has led to a proliferation of diverse approaches to certification, incentive and warranty programs, and building code provisions. Diversity and proliferation have caused great confusion to legislators and consumers alike, a confusion that can be ended only when all players are using the same set of rules $-a$ consistent set of standards. In the absence of standards legislatures are attempting to fill the vacuum, thus creating an opportunity to judge a variety of approaches. Until consistency becomes the rule rather than the exception, reciprocity between states can help to cure the proliferation of approaches to solar technology. The federal role in acceleratng the development of standards without taking over the process can aid in: (1) developing consumer acceptance of solar technology applications and (2) developing an industry infrastructure. Only by reducing confusion and promulgating a common language can the overall goal of accelerated commercialization of solar technology applications be reached. 
TR-095

S=P蕃 


\section{REFERENCES}

1. Energy Policy Project of the National Conference of State Legislatures, Energy Report to the States. (Apr. 1978).

2. Solar Engineering. (May 1978).

3. See Barbier v. Connolly, 113 U.S. 27, 31 (1885); Railroad Co. v. Husen, 95 U.S. 465, 471 (1878); Noble State Bank v. Haskell, 219 U.S. 104, 111 (1911); People v. Willi, 179 N.Y. Supp. 542, 548 (N.Y. 1919).

4. McCulloch v. Maryland, 4 Wheat. 316, 436 (U.S. 1819).

5. Heart of Atlanta Motel v. United States, 379 U.S. 241 (1964).

6. California v. Zook, 336 U.S. 725, 728 (1949).

7. Ind. Code, § 6-1.1-12-26 (Supp. 1977).

8. Cal. Rev. and Tax Code, $\$ 17052.5$ (West Supp. 1976).

9. Form 3805L, "Statement to Support Solar Energy Credit," State of California Franchise Tax Board (Jan. 1976).

10. Mass. Ann. Laws, Ch. 59, $\$ 5, ~ \Uparrow 45$ (Michie/Law Coop-1978).

11. Personal conversation with Jeff Brower of the Massachusetts Energy Policy Office, Solar Division.

12. New Mexico Solar Heating and Cooling Regulations, S.T.C. Regulations, 11.3(A):8.

13. Pinellas County, Florida, Solar Heater Standards Code (Jul. 22, 1975), reprinted in Florida, Solar Energy Center, Solar Energy Commercialization at the State Level: The Florida Solar Energy Water Heater Program, 36 (1977).

14. Minn. Stat. Ann., $\$ 116$ H.127 (West 1976).

15. Wash. Rev. Code Ann., \$ 84.36.410 (Supp. 1977).

16. N.C. Gen. Stat., \$ 105-151.2 (Supp. 1977).

17. Md. Code Ann., $\$ 81-12 F-5$ (Supp. 1976).

18. Conn. Gen. Stat. Ann., \$ 12-81 (West Supp. 1977).

19. Fla. Stat. Ann., $\$ 377.705(1)-(4)$ (West Supp. 1976).

20. N.M. Laws, Vol. III, Ch. 347 (1977).

21. Ore. Rev, Stat,, \$ 469.175 (Supp. 1977).

22. Wis. Stat., $\$ 71.09$ (12) (1977). 
23. HUD, Solar Status, A special report published by the U.S. Department of Housing and Urban Development, Solar Demonstration Program, in cooperation with the U.S. Department of Energy (March 1978).

24. California Energy Commission, "Standards and Procedures: Accreditation of Testing Laboratories for Solar Components and Systems" (May 1978).

25. California Energy Commission Committee Certification of Solar Energy Equipment Regulations and Guidelines, Revision to Tax Credit Guidelines and Criteria, Accreditation of Testing Labs, Final Regulations and Guidelines. (May 1978).

26. 15 U.S.C., $\$ 2301(6)$ (Supp. 1977).

27. Personal Conversation with Howard Kraye, Director, California Solar Energy Industries Association (Chapter of International Solar Energy Society).

28. Legal-Institutional Implications of Wind Energy Conversion Systems (WECS): Report to the National Science Foundation, NSF/RA-770203 p: 70-72.

29. Field, Charles and Rivkin, Steven, The Building Code Burden, Lexington Books, Lexing ton, Mass. (1975).

30. Schoen, Richard; Hirschberg, Allan; and Weingart, Jerome M., New Energy Technologies for Buildings, Ballinger Publishing Co., Cambridge, Mass. (1975), p. 177.

31. General Electric Study to Define Impact of Statewide Building Codes on Solar HVAC Systems, Commercial Buildings (NTIS: COO/2683-76-11).

32. Mecker, Frank, Building Codes as Barriers to Solar Heating and Coolıng of Büiläings, Environmental Law Institute (1978).

33. Sanderson, Richard, Codes and Administration: An Introduction to Building Regulations in the United States, Building Officials Conference of America: Chicago (1969), pp. 40-43.

34. Plan for the Development and Implementation of Standards for Solar Heating and Cooling Applications (NBSIR 78-1 143A), p. 15.

35. 2 MCAR $\$ 1-1.16108$, "Standards of Performance for Solar Energy Systems and Subsystems Applied to Energy Needs of Buildings."

36. N.M.S.A. 67-35-13F (1953).

37. "1972 Heating, Ventilating, and Air Conditioning Code of the City of Atlanta," $\$$ 2401 (Amended Feb. 15, 1977). 


\section{APPENDIX B}

\section{SOLAR HEATING AND COOLNG SYSTEMS}

\section{HISTORY}

Using the sun's energy to bring about efficient and effective heating and cooling of buildings is not a new idea. Appropriate materials and building orientations for a geographic locality have been used by many cultures through history. This early application of solar energy is associated with passive solar energy designs. In addition, using the sun's energy to heat water has evolved in various ways. From the 1920s to 1950 s many residents in California and Florida used solar water heaters. It has been estimated that the Miami area had more than 50,000 solar water heaters in use in 1951 [1].

Research and development activities in the United States for solar collector space heating applications were evident in the late 1950s. During this time forced circulation hot air and hot water systems were developed and demonstrated by George Lof and the Massachusetts Institute of Technology (MIT).

Federal research, development, and demonstration in solar space cooling and passive design have begun within the last few years. These programs apply developments in related technology areas of heat pump and Rankine cycle engine development to the subsystems required for solar space cooling and passive application [2].

\section{PRINCIPLE OF OPERATION}

\section{Active Systems}

Solar space heating and water heating systems operate on the same principle. A solar collector is used to collect incident solar radiation and convert it to thermal energy which is then used to heat a working fluid (gaseous or liquid). The heated fluid is transported to the point where it is applied to space heating or cooling or to hot water heating. The heated working fluid can also be used to charge a thermal energy storage unit.

- Solar space and water heating applications generally use flat-plate collectors, which normally consist of a metallic absorption plate (usually steel, cooper, or aluminum) with integral or attached thermally bonded tubing. The plate is backed by an insulation material to prevent heat loss through the back of the collector. The absorption plate and insulation are usually placed in a metal container which is then covered with one or two sheets of translucent material (glass or plastic) and sealed hermetically. Lower temperature collectors, commonly used to heat swimming pools, include only an absorption plate.

Solar space cooling commonly requires working fluid temperatures above $165^{\circ} \mathrm{F}$., which are higher than those for space and water heating system. The higher temperaturee aro needed to evaporate a working fluid within the absorption cooling unit, which initiates the series of cyclic changes in the thermodynamic state of the working fluid needed to 
drive the solar cooling system. The process is similar to that required for refrigerators and air conditioners. Thus after the sun's energy is collected it is transformed to a second energy form before its end use is obtained. The higher temperatures are attained by using special, selectively coated double-glazed flat-plate or concentrating collectors, such as focusing or tubular glass collectors, which average $212^{\circ} \mathrm{F}$ to $350^{\circ} \mathrm{F}$. The concentration of radiation on a small area enables concentrating collectors to generate higher temperatures than flat-plate collectors.

Solar space heating and cooling and water heating collectors are positioned on the ground or on roofs to face south (optimally). The collector is only part of the total solar system. Other subsystems include storage, distribution/control, and an auxiliary or backup system.

\section{Passive Systems}

Passive systems are capable of space heating and cooling and water heating. Their use is characterized by the absence of an auxilary energy source to circulate the solar-heated or climatically cooled fluid (gaseous or liquid). Auxiliary heating systems can be utilized to back up the passive system.

As in active systems, passive solar systems have solar collection, storage, and distribution/control components. However, in passive systems these components are an integral part of the structure. Examples are south-facing glass for collection, mansonry wall in front of the glass for storage, and a roll-down insulated curtain for control. Passive solar cooling systems use the same thermal mass technologies of solar radiation directly heating the mass; inherent characteristics of the climate (such as night sky radiation, cool evening breezes, evaporation of water) are used to cool the thermal storage. Passive systems utilize proper building orientation and landscape design.

\section{THE FEDERAL SOLAR HEATING AND COOLING PROGRAM}

\section{Federal Funding}

Prior to 1971, federal support for solar heating and cooling research and development for residential, commercial, and industrial applications was not significant. In 1971, the National Science Foundation (NSF) funded such support through the Research Applied to National Needs (RANN) programs. From fiscal year 1971 (FY71) through FY73 R\&D funding for solar heating and cooling of buildings (SHACOB) was approximately $\$ 540,000$ per year [2]. In 1974 the Solar Heating and Cooling Demonstration Act of 1974 (Public Law 93-409) was passed by Congress. The Act provided for the development and demonstration of solar heating and cooling technology in residential and commercial buildings. The Energy Reorganization Act of 1974 (Public Law 93-438) transferred all NSF solar activities to the Energy Research and Development Agency (ERDA). These ERDA programs were transferred to the Development of Energy (DOE) in FY77. The FY77 and FY78 budgets for SHACOB research, development, and demonstration were $\$ 86.5$ million and $\$ 95.9$ million, respectively. The projected budget for FY79 is $\$ 128.7$ million [3]. 


\section{Federal Program Structure}

The primary goal of the program is to work with industry in the development and early introduction of economically competitive and environmentally acceptable solar energy systems to meet national energy requirements [4]. To obtain this goal the program has identified seven major subprogram elements:

- Residential and Commercial Demonstrations,

- Demonștration Program Development Support,

- "Research and Development,

- Data Collection, Evaluation, and Dissemination,

- Standards and Performance Criteria,

- Environmental and Resource Assessment, and

- Market Development.

Within DOE the federal solar heating and cooling program is managed by two divisions: the Energy Technology (ET) Division and the Conservation and Solar Application (CSA) Division. ET is responsible for most of the program's R\&D activities. CSA is responsible for the commercialization activities such as standards, market development, and demonstration projects. The programs of ET and CSA are supported by several federal agencies and laboratories. The solar heating and cooling systems development programs are implemented primarily by contracts and grants with industry. The majority of the solar collector $R \& D$ projects have been awarded to private firms. Thermal storage heat exchanger and heat pump research is divided among federal laboratories, universities, and businesses. Solar cooling system $R \& D$ is also being performed by federal laboratories, universities, and businesses. Approximately $60 \%$ of the research projects for passive applications are being performed by business and $40 \%$ by federal laboratories and universities. Advanced systems development is concentrated in universities and federal laboratories. Systems analysis and control research is performed by federal laboratories, universities, and private firms. Support projects are being done almost completely by federal laboratories and universities (2).

Demonstation and commercialization projects are managed primarily by DOE and HUD. Other participating agencies include the Department of Defense, Government Services Administration, Tennessee Valley Authority, United States Postal Service, Department of the Interior, National Aeronautics and Space Administration, Veteran's Administration, Department of Justice, Treasury Department, and the Department of Agriculture. The projects are being done by members from all sectors of the solar industry infrastructure [5]. Most residential demonstration projects are being performed through the IHD demonstration grant cycle program.

System performance data and building code compliance experience information obtained from demonstration programs are being used in DOE SHACOB program planning efforts. Based on these data, reliability, durability, maintainability, performance, and safety issues, especially with regard to standards development and system design, are receiving increased emphasis. 


\section{TECHNOLOGY RESEARCH STATUS}

\section{Solar Space Heating}

The current federal $R \& D$ program is structured to develop solar applications through demonstration. The $R \& D$ program stresses continued component and systems develpment to improve efficiency, reliability, and cost effectiveness. As such, the technology is in the introduction and diffusion phases of the commercialization process. The product test stage in support of standard development activities and increased production stages are occurring simultaneously.

Most of the 84 solar collector research projects [2] concentrate on improving basic performance concepts and materials 'with the overall objective of improving the system's cost effectiveness. Research in storage, heat exchanger, and collector connecting methods is underway. Programs to improve design and construction techniques to facilitate solar collector mass production are also being initiated. These projects will provide performance data critical to standards development activities.

\section{Solar Space Cooling}

Solar space cooling systems are in the applied research and development phases of the commercialization process. Applied research and advanced R\&D were initated in FY77 on desiccant, Rankine, and absorption systems. The program's emphasis is to develop solar space cooling systems that are economically competitive with traditional space ronling syst.ems.

Research programs for solar space cooling focuses on modeling and projecting solar equipment performance parameters and to the design, construction, and test of breadboard and prototype equipment. Two of the $26 \mathrm{R} \& \mathrm{D}$ projects for solar space cooling systems specifically address the reliability, durability, and maintenance engineering requirements of the systems being developed: a solar powered Rankine cycle/vapor compression cycle cooler and solar cooling system using a desiccant dehumidifier cooling unit [2].

\section{Solar Passive Applicatioñs}

Attention is being given to defining what constitutes a solar passive application (primarily for tax credit programs) and cost effectiveness per application. The research and development activities work to provide a greater understanding of solar gain, heat storage, and heat release character istics for various applications [6].

\section{STANDARDS STATUS}

Standards for solar space heating and cooling and water heating systems and components are being developed according to guidelines in the "Plan for the Development and Implementation of Standards for Solar Heating and Cooling Applications" (NBSIR-78$1143 A$ ) prepared by the National Bureau of Standards (NBS) working with the ANSI Solar Standdards Steering Committee(SSSC), DOE, and HUD. The plan identifies standards needed for SHACOB (primarily active systems), and defines priorities, responsible parties, and-schedules for development. The plan also presents the status of solar standards development for SHACOB. 


\section{Voluntary Consensus Standards}

The American Society for Heating, Refrigeration, Air Conditioning Engineers (ASHRAE) has issued two industry consensus standards:

- ASHARE 93-77 "Methods of Testing to Determine the Thermal Performance of Solar Collectors," effective July 1977.

- ASHRAE 94-77 "Methods of Testing Thermal Storage Devices Based on Thermal Performance," effective July 1977.

These test procedures are based on draft standards previously developed by NBS in FY75, To keep abreast of technology developments, these standards are being reviewed by ASHARE subcommittees. For example, the procedure for measuring air flow in air collector testing in ASHRAE 93-77 is particularly rigid and is being revised to permit new technologies to be employed [7].

Numerous standards are under development by ASHRAE, American Society for Testing and Materials (ASTM), American Society of Mechanical Engineers (ASME), Underwriters Laboratories (UL), Solar Energy Research and Education Foundation (SEREF), and National Bureau of Standards (NBS) [8].

These activities focus on the development of voluntary consensus standards for the following in the noted time frames:

- Standard test methods for thermal performance measurement for active space (fall 1979), hot water (fall 1978), swimming pool heating systems (fall 1978), and collector insulation (spring 1979).

- Standard test methods for optical performance measurement of functional materials (cover plates (1982-83) and absorber coatings (1981)].

- Standard test methods for durability/reliability measurement for:

* Active (liquid) system materials interaction (summer 1980),

* Active (liquid) component reliability (summer 1979),

* Active (liquid) component durability (summer 1980), and

* functional materials:

- coverplates (fall 1979),

- absorber coating-outdoor exposure (spring 1979)

- absorber coating-general testing (winter 1979),

- absorber plate material-metal fluid pans-screening (fall 1979)

- absorber plate material-metal corrosion/system service test (1982),

- absorber plate material-nonmetallic containment material (1982),

- collector insulation (fall 1981) and

- general materials-outgasing (summer 1980).

- Standard methods of testing for collector fire resistance and impact determination (spring 1979). 
- Standard recommended practices for the design and selection of:

* residential domestic hot water (summer 1980),

* residential space heating (summer 1980), and

* sensible heat thermal storage (fall 1980).

- Standard recommended practices for installation active space heating systems (winter 1980).

- Standard performance specifications for:

* flat-plate collector gaskets and sealants (fall 1979),

$\checkmark \quad$ other than flat-plate collector gaskets and sealants (summer 1979), and

* seals contact with fluids in collector gaskets and sealants (summer 1979) and,

* flexible connections (summer 1981).

- Standards for qualification/accreditation of laboratories for active collectors (winter 1980).

- Standards for certification of active collectors (winter 1980).

Most of these standard development activities start with NBS developing a draft test method. This initial draft is generally done in conjunction with one of the professional societies. A draft is then reviewed and modified as appropriate by a subcommittee of the standards-writing organization and follows development procedures for approval as an American National Standard.

Depending on the nature of the vetoes and the modifications required to acommodate comments, a voluntary consensus standard usually evolves within two to five years after the balloting process.

There is an impetus to accelerate the industry consensus standards process. Standards are needed to support consumer confidence and acceptance of solar energy products. Further, standards are needed to support the development of an industry infrastructure concomitant with federal program goals and incentive in accelerating the commercialization of the solar technologies.

Effort is being made by the standards-setting institutions to shorten the standards process to nine to twelve months for solar standards. Support for the acceleration of these activities is being provided by the federal government in the form of funding for subcommittee travel and service support activities.

Acceleration of the process did occur in the development of ASHRAE 94-77. the standard required eight months from the release of the NBS draft to approval as an American National Standard. Not since 1906 when the Sheet Metal and Air Conditioning Association first published a standard has a voluntary consensus organization developed a major standard in so short a time [9].

The noted standard development activities-identified in the plan have been identified by the SSSC as those with the highest priority. This is not meant to imply that these are the only standards requiring further development. Standard test methods for measuring the durability and reliability of components such as pumps, valves, and regulators are examples of standards that may require modification for solar applications. 


\section{Contrator Association Standards}

The Sheet Metal and Air Conditioning Contractors National Association (SMACNA) in March of 1978 published the third edition of the Heating and Air Conditioning Systems Installation Standards: "Heating and Air Conditioning Systems-Installation Standards for One and Two Family Dwellings and Multifamily Housing Including Solar." The standards were developed with funds from DOE and administered by HUD.

In addition to establishing its own standards for work quality, the Sheet Metal Workers Union added nine hours of instruction on solar installation to its four-year apprenticeship program. The involvement of industries such as SMACNA in these important institutional roles contributes to the successful commercialization of the solar technologies.

\section{Government Standard Programs}

In compliance with Public Law 93-409, "Solar Heating and Cooling Demonstration Act of 1974," NBS prepared for HUD in January 1975 the "Interim Performance Criteria for Solar Heating and Cooling Systems and Dwellings" to use in the residential demonstration program. The National Aeronautics and Space Administration (NASA) developed interim performance criteria for commercial solar heating and cooling systems and facilities for ERDA to use in the commercial demonstration program. NBS revised the NASA procedures in 1976 as the "Interim Performance Criteria for Solar Heating and Cooling Systems in Commercial Buildings."

NBS developed the HUD "Intermediate Minimum Property Standards (MPS) for Solar Heating and Domestic Hot Water Systems" (1977). The standards act as a supplement to the HUD MPS, which is used as the basis for mortgage insurance acceptance of systems components by HUD/FHA.

NBS also developed the "Intermediate Standards for Solar Domestic Hot Water Systems" (July 1977). These standards are being used in the HUD Solar Hot Water Initiative Program, which provides monetary assistance to homeowners to install solar domestic hot water systems [8].

In addition to interim performance criteria, the Act requires that definitive performance criteria for solar heating and combined heating and cooling components and systems to be used in residential dwellings be developed at the earliest possible date. The criteria are to be based on the data obtained from the demonstration projects by NBS. The development of definitive performance criteria for residential and commercial applications is anticipated to be completed in the next few years.

The Act further requires that test procedures be developed to provide certification that solar heating and combined solar heating and cooling components and systems conform to the performance criteria. The development of such a certification program was initiated in 1977. NBS contracted with the ARI Foundation (ARIF), Inc., a subsidiary of the Air Conditioning and Refrigeration Institute, to identify laboratories qualified to test solar collectors in accordance with ASHR AE 93-77. In performming this task, ARIF developed criteria for evaluating test laboratory qualifications. In late $1977 \mathrm{FEA}$ (DOE) awarded a contract to the Solar Energy Research and Education Foundation (SEREF), a subsidiary of the Solar Energy Industries Association (SEIA), to design a program for physical testing, rating, certification, and labeling of solar collectors. SEREF is also developing procedures for accrediting laboratories for testing solar collectors [10]. 
The SEREF contract is expected to be completed in 1979. the overall goal of the SEREF program is to produce a system for performing laboratory accreditation, collector rating, certification, and labeling that will be adopted by the industry. SEIA is establishing such program.

In the SEIA program, each collector manufacturer will be required to submit ASHRAE 93-77 thermal performance test data, based on tests by a SEIA accredited laboratory, with the rating which the manufacturer requests, based on application of the SEIA rating method to the test data. The collector manufacturer will then be licensed to affix a SEIA label with the rating information on the collectors.

The SEREF program will be presented as a draft for standards development to the ANSI Solar Standards Steering Committee. To be considered as a consensus standards, ANSI requires participation of principal interest groups in the development of the proposed standards. Accordingly, SEREF has established a Steering Committee for the project. Representative industry, association, and interest group members of the Steering Commmittee are [11]:

- SEIA,

- OLIN BRASS,

- SEREF,

- GE,

- Ametek, In.-Power Systems Group,

- Desert Sunshine Exposure Tests, Ine.,

- American Institute of Architects,

- Hydronics Institute,

- Consumer Action Now,

- ANSI,

- Consưumer Union, and

- ARI.

In addition, working committees include interest groups for the following contract elements: Lab Accreditation Program, Reliability and Durability Program, the Rating Methods Program, and the Certification and Labeling Program.

\section{DOE Interim Collector 'Ihermal Performance Testing Program}

In this program laboratories were identified as having the equipment and personnel to perform solar collector testing in accordance with ASHRAE 93-77. The qualified laboratories are being used in a solar collector testing program sponsored by DOE's Office of Solar Applications. Approximately 150 solar collectors are being tested. DOE is providing financial assistance to manufacturers for testing one collector model. The intent of the Collector Testing Program is to obtain performance data on representative collectors on the market and to use these data in the rating system being developed by SEREF. The rating results will be published in a catalog. Testing is expected to be complete in early 1979. 
As an adjunct to the testing and catalog of collector ratings, a limited physical testing program using NBSIR-77-1305, "Provisional Flat-Plate Solar Collector Testing Procedures," is being performed with approximately 25 generic types of solar collectors. The program will provide a data base for the NBS revision of this procedure and subsequent development of industry consensus physical test procedures. The testing program is expected to be finished by the first quarter of 1979. Voluntary consensus standards are anticipated for reliability test procedures in June 1979 and durability test methods in June $1980[8]$.

NBS has instituted a program to administer a National Voluntary Laboratory Accreditation Program (NVLAP). The goal of the program is to provide, in cooperation with the private sector, a national voluntary system to examine upon request the professional and technical competence of private and public testing laboratories that serve regulatory and nonregulatory product and certification needs. The program is also intended to accredit those laboratories that meet the qualifications established under these procedures. This role has traditionally fallen under the jurisdiction of state and locl governments and industry associations. SEIA is proceeding with the development of the SEREF program and its laboratory accreditation program, because there is a desire within the solar industry to keep laboratory accreditation and certification programs in the private sector.

A principal objective of these testing, rating, lab accreditation, and certification programs is to provide consumers with some measure of confidence in solar collectors. A means to evaluate solar collectors is needed not only by consumers, however, but by building code officials responsible for ensuring that the installed collector complies with the health and safety intent of building code provisions. Building codes generally place the responsibility of certifying equipment with industry. The lack of a "seal of approval" by a recognized authority such as UL or ARI places the responsibility on the building code official to determine whether the collector or equipment is safe. As such, the building code official may require extensive testing and review procedures for each collector installed, or, as is more of ten the case, he may add uncertainty and increased time to the process by postponing approval.

Existing building codes do not cover the health and safety characteristics of solar systems, although they may cover analogous equipment or structural elements of the building. A significant problem is that building inspectors currently have no document(s) to reference analogous standards. In addition, codes traditionally have ensured compliance with health and safety provisions and have not promoted the comfort of building interiors. Building officials need a consistent set of national standards for judging the safety characteristics of solar equipment. Otherwise, they may be unwilling to approve systems they do not understand or in which they are unable to evaluate the quality of installation [12]. Interim provisions for uniform solar safety and health requirements are needed.

The solar collector rating method being developed by SEREF is a beginning step in helping building.code officials assess the ability of a collector to meet health and safety reuirements. Acceleration of the SEREFF program and subsequent adoption of a solar collector testing and labeling program that includes safety considerations are critical to the success of the solar commercialization program [13]. However, the collector rating method is limited in that it addresses only thermal performance of the collector, not systems, other components, or passive systems.

In addition to standard measures of reliability and durability for safety issues, environmental and health standards are important. Numerous federal and state regulations for 
health and safety apply to solar collector manufacture, installation, and operation. DOE has established an environmental and resource assessment program to ensure that the developing solar energy systems will have desirable environmental and safety characteristics and will not pose demands on scarce domestic resources [14].

Three issues relating to solar heating and cooling technology development that affect health and safety have been identified: water contamination, collector overheating and fire impacts, and handling and disposal of system fluids and wastes. (None of these issues is being addressed in terms of passive applications.)

- Leakage of solar system working fluids and additives into the domestic hot water system could contaminate the potable water supply. One primary concern is the highly toxic properties of certain fluids and additives, particularly chromates and nitrates.

- Collector overheating and fire could be major concerns due to the cumbustion and decomposition properties of candidate solar heating and cooling matcrinls. Emission of toxic substances is the primary concern.

- Improper handling and disposal of system fluids and wastes may result in pollution of local waterways and ecosystems. Sewage treatment plants also may be affected.

Studies are underway or planned to assess the potential impacts of these issues and to develop effective control and mitigation methods [14]. Part of this research involves identifying standards currently applicable to the solar system applications and institutions responsible for modifying or developing standards, For example, the National Institute of Occupational Safety and Health has set maximum permissible concentration levels of toluence dusocyanate (TDI). TDI is released when plastics or synthetics degrade at high temperatures. This condition could occur if collector overheats and outgasses (the release of highly toxic substances under overheat or fume conditions). The American Conference of Governmental Industrial Hygienists (AGGIH) has established limits for hydrofluoric liquid and gas emissions. Further, the American Public Health Association has developed "Standard Methods for Examination of Water and Waste Water." These standards are in addition to EPA regulations on air and water emissions, solid-waste disposal, and toxic material handling.

The interest in consumer protection and building code requirements is not limited to the federal government. States are becoming involved in establishing programs to meet these needs. A potential problem with these actions is the creation of multiple and costly requirements on an emerging industry unable to support such actions.

\section{State Standards}

Florida and California have established solar equipment testing, certification, and labeling programs. The 1976 Florida Legislature enacted the Solar Energy Standards Act of 1976, now Section 377.705, of the Florida Statutes. Effective October 1, 1976, the law directed the Florida Solar energy Center (FSEC) to develop standards for solar energy equipment sold or manufactured in the state, to establish criteria for determining the performance of solar energy equipment, and to maintain a testing facility for solar energy equipment performance. As a result of this directive, FSEC prepared FSEC 77-6, "Operation of the Collector Certification Program," which presents details of the testing and standards program whereby solar collectors may be rated for performance, examined 
for compliance to minimum standards, and approved to bear a label of certification from FSEC. Testing for this program includes:

- receiving inspection,

- static pressure test (2x operating pressure),

- thermal performance test (NBS and ASHRAE 93-77),

- exposure test (30 days at $1500 \mathrm{Btu} / \mathrm{ft}^{2} /$ day),

- spray and thermal shock,

- thermal performance recheck, and

- quality check for degradation.

Participation in the program was voluntary. However, a recent amendment provides that collectors manufactured or sold within the state must bear a certification lable [15]. Certification means the collector model meets the minimum standards required by the state. These standards are presented in the "Florida Solar Energy Center Test Methods and Minimum Standards for Solar Collectors," June 1977, FSEC 77-5. Consumers may also request a free summary information package from the center listing the physical dimensions of each tested collector and materials used in its manufacture.

California Assembly Bill 1512 requires the California Energy Commission (CEC) to develop and adopt on or before November 1, 1978, in cooperation with affected industry and consumer representatives, regulations governing solar energy equipment. On February 1, 1978, the CEC adopted preliminary regulations and guidelines establishing standards and procedures to accredit testing laboratories for solar equipment. The Testing and Inspection Program for Solar Equipment (TIPSE) currently applies only to flat-plate collectors. Other solar components will be added when test methods are available. The program is using ASHARE 93-77 as the thermal performance test method and several reliability test methods cited in NBSIR 77-1305. This program is similar to Florida's solar quipment test program. A reciprocity agreement between the two states to accept each other's laboratory results has been established [16].

Numerous states have passed legislation that require some form of consumer protection standards for solar systems (Connecticut, California, Florida, Minnesota) or solar equipment (New Mexico). In addition, ten states (California, nlinois, Maine, New Jersey, New Mexico, North Carolina, Oregon, Tenneessee, Washington, and Wisconsin) require standards to support legislated solar tax credit programs [17]. Except for Florida and California, these states do not have ongoing testing, certification, or labeling programs. The states appear to be assessing alternative approaches to satisfy the legislation and looking to the federal government and industry to institute programs for state adoption.

The solar industry supports states' activities to enhance the market potential of solar applications through programs such as the tax credit program. However, there is concern that excessive, redundant, and nonessential testing requirements to support these efforts may severely affect the industry.

According to some members of the industry, some government agencies tend to suggest a number of testing requirements as a "shopping list" for other agencies in procuring solar devices and systems. The intent is to have the other agencies choose specific testing requirements to fit their needs. It may happen that the "shopping lists" are adopted in total by regulatory agencies with the result that the test requirements imposed upon the manufacturers become both confusing and excessively expensive. 
As noted in the discussions in this section, most of the standards activities for SHACOB are for flat-plate liquid solar collectors. This can be partially attributed to the existence of flat plate collectors as the only high cost, new technology in most active solar systems, thus requiring longer term and perhaps more extensive research. However, programs to develop data bases for passive solar applications are underway or planned [4], and studies to define passive applications for tax credit programs are underway. A Passive Systems Program Office has been established in DOE to highlight this new awareness of the needs of passive systems. A Passive Program Plan is currently being developed, and publication is expected in FY79. It is expected that the plan will outline a standards development program for passive systems. The lack of an institutional framework to support such efforts has limited progress to date.

Additional discussion of state and local standards development activities is found in Appendix $A$ of this report.

\section{BUILDING CODE STATUS}

\section{National Model Codes}

The three national model codes do not specifically address the installation or operation of solar space heating and cooling and water heating systems [12]. Much debate has centered on whether the lack of specific provision for SHACOB in building codes is a barrier to widespread use of solar systems. It has been argued that:

- all elements of solar heating systems can be designed to conform with code requirements with little effect on performance or cost [18], and

- building regulations are no more stringent for solar installations than for other construction if the builder provides the building official with thorough plans and project specifications [19].

The following issues support the contention that the lack of specific solar references in codes may be restrictive:

- the absence of specific regulation (re solar) is a greater problem than given code restrictions [12], and

- current building codes are simultaneously too vague in some areas while too stringent in others. In some cases the building of ficial is given considerable room for judgment, while in others very specific requirements are provided [19].

To respond to these concerns, several activities addressing building codes and SHACOB have occurred or are in process. At the national level, the Internatinal Association of Plumbing and Mechanical Officials (IAPMO) prepared and published a model solar code in September 1976, entitled the "Uniform Solar Energy Code." The provisions of the document apply to the erection, installation, alteration, addition, repair, relocation, replacement, maintenance, or use of any solar system. The code has been criticized [20, 21] for its errors, omissions, and lack of reference to the evolving federal and national standards for SHACOB, and is currently under revision. It has been adopted by several municipalities that use the International Conference of Building Officials (ICBO) model code entitled "The Unif orm Building Code." 
At the federal level, NBS awarded eight contracts in 1977 to examine all the existing model codes to determine whether they contained conflicts that could deter the use of solar technology. The contracts were awarded to:

- The Southern Building Code Congress International, Inc. (SBCCI),

- The Building Officials and Code Administrators International, Inc. (BOCA),

- The International Conference of Building Officials (ICBO),

- The National Conference of States on Building Codes and Standards (NCSBCS),

- The National Institute of Building Sciences (NIBS),

- The American Society of Heating, Refrigeration and Air Conditioning Engineers (ASHRAE),

- The Council of American Building Officials (CABO), and

- The American Institute of Architects/Research Corporation (AIA/RC) [22] .

These reviews concluded that conflicts did not exist in the codes, but some provisions should be incorporated and some code areas needed more data [10]. These recommendations are being addressed by the model code groups and the DOE. Public hearings were held in May 1978 on a model solar code. It is anticipated that an industry consensus standard on a model solar code will be generated by 1979 through the efforts of the professional building and code societies, the solar industry, and the consumer with local, state, and federal participation and support [8]. It is anticipated that this model solar code will be adopted by the states and local governments to provide uniform guidance to building officials.

\section{State and Local Building Codes}

Several states, including California, Florida, New Mexico and Nebraska, have passed legislation specifically addressing building code regulation and SHACOB. Callfornia requires that all state housing be constructed such that buildings may be retrofit with solar systems when the systems become cost effective. Florida requires that all residential plumbing be installed so that solar retrofits can be made. New Mexico has adopted the IAPMO Uniform Solar Energy Code. Nebraska requires that solar applications be considered in determining building energy requirements and savings in order to comply with the state's building energy conservation guidelines [17].

Federal law requires states to adopt by 1980 energy conservation legislation setting guidelines for building energy consumption in order to be eligible for federal assistance in building construction. Many states are adopting the ASHRAE 90-75 performance standard for buildings. The adequacy of this standard to effect energy savings has been questioned by several states. In addition, concern about the standard's potential negative impact on solar installations has also been expressed. As a result, California repealed its adoption of ASHRAE 90-75 and New Mexico has adopted a revised version of ASHRAE 90-75.

The principal concerns with ASHRAE 90-75 are:

- its lack of allowance for the use of solar applications in computing the building's energy requirements, and 
- the potential negative effect of the steady state $U$ value in solar passive applications energy calculations. (A U value is a measure of a material's ability to conduct heat. A steady state $U$ value assumes this property is constant.)

New Mexico revised the $U$ value computation to allow the use of an "effective" $U$ value, which attempts to consider the thermal characteristics of masonry building components and the daily heat flow through a wall [23].

ASHRAE 90-75 is currently being reviewed with respect to these issues as part of the building Energy Performance Standards (BEPS) by HUD and DOE. The BEPS, to be a national energy conservation code for new buildings, is expected to be adopted by the states in late summer of 1979.

Several local governments have instituted guidelines or code provisions addressing SHACOB. LOS Angeles, California, has established a code that sets minimum guidelines for building and safety code provisions relative to all hydraulic solar heating and cooling systems and specifies a list of approved materials to be used in SHACOB construction. Materials not listed must be tested by a laboratory accredited by Los Angeles. In addition, the code establishes fees for laboratory approval of a system installed in the Los Angeles code jurisdiction: a $\$ 690$ fee for initial system approval and a $\$ 305$ fee for yearly renewal. This code is under the Los Angeles Department of Building and Safety Approval. The intent of the approval and subsequent labeling program is to ensure system safety and reliability [24]. The code does not reference evolving federal or industry standards.

Davis, California, as part of its innovative energy conservation ordinance, gives special consideration to solar systems, particularly passive applications. Window shading, vegetation location, and building orientation are specifically required to be responsive to the angle and orientation of the sun. Anaheim, California, and Ft. Lauderdale, Florida, amended codes that previously denied the installation of heating, ventilation, and cooling equipment on roofs to allow roof-mounted solar systems.

To date, building codes have created relatively few real problems for solar installations [19], perhaps because of the relatively small number of applications compared to all building starts per year or to the attention given to each installation when it is presented to the building code officials. Accordingly, state and local governments appear to be waiting for federal and industry action on building codes before becoming extensively involved.

Additional discussion of state and local building code issues is contained in Appendix A of this report. 


\section{REFERENCES}

1. Hottel, H.C. "Residential Users of Solar Energy," Proceedings of the World Symposium on Applied Solar Energy, Stanford Research Institute, 1955, pp. 103-112.

2. DOE, Solar Heating and Cooling Research and Development Project Summaries (May 1978).

3. General Accounting Office, Report of the Comptroller General of the United States: The Magnitude of the Federal Solar Energy Program and the Effects of Different Levels of funding (February 1978).

4. DOE, Solar Energy-A Status Report (June 1978).

5. DOE, Solar Heating and Cooling Demonstration Project Summaries (May 1978).

6. SERI, Economic Feasibility and Market Readiness of Eight Solar Technologies, Interim Draft Report (June 1978).

7. Zerlaut, Gene, "Solar Standards," Alternate Architecture (Feb.-Mar. 1978).

8. Waksman, D., Pielert, J. H., Dikkers, R.D., Steel, E.R., and Niessing, W.J., "Plan for the Development and Implementation of Standards for Solar Heating and Cooling Applications," NBS IR 78-1193A (June 1978).

9. McPherson, Elizabeth, "Some News is Better than None," Solar Age, (March 1977).

10. Oddo Sandra, "A Progress Report-Standards and Codes," Solar Age [May 1978).

11. Butt, Sheldon, "New from SEIA-Update on Collector Tests and Standards," Solar Fnginepring (April 1978).

12. Meeker, Frank D., "Building Codes as Barriers to Solar Heating and Cooling of Buildings," Environmental Law Institute, Washington, D.C. (April 1978).

13. "National Certification: Where are the Standards?" Solar Engineering (February 1978).

14. DOE, Solar Program Assessment: Environmental Factors-Solar Heating and Cooling of Building (March 1977).

15. Ch. 309, 1978 Florida. Laws; Florida. Stat. 377.705(d).

16. Personal Communication with Mike De Angeles, CEC (June 1978).

17. National Solar Heating and Cooling Information Center, State Solar Legislation (July 1978).

18. NBS, Research and Innovation in the Building Regulatory Process, Proceedings of the First NBS/NCSBCS Joint Conference, September 21 and 22, 1976 (June 1977). 
19. Hill, Gladwin, "Thicket of Restrictions Impeding the Use of Solar Devices," The New York Times (July 1978).

20. American Institute of Architects Codes and Regulations Center, "Solar Energy Code: From Flaw to Law," CRC3 (No. 3, 1976).

21. American Institute of Architects Codes and Regulations Center, "IAMPO Publishes Uniform Solar Energy Code," CRC3 (No. 3, 1976).

22. HUD, "HUD Solar Status-Special Report" (March 1978).

23. New Mexico Solar Energy Association Newsletter (Nov. 1977).

24. "Los Angeles Code Among the First for Solar Systems," Solar Engineering (Aug. 1977). 
APPENDIX C

\section{AGRICULTURAL AND INDUSTRIAL PROCESS HEAT SYSTEMS}

\section{HISTORY}

Agricultural and industrial process heat (AIPH) systems use the heat collected from the sun in drying, curing, water heating, and process steam applications. This heat energy is collected in a variety of ways that range from simple direct exposure of the material being processed to the sun's rays to the collection of radiant heat and its conversion to sensible heat in a working fluid by sophisticated collector hardware equipment. The use of the sun's energy in the first case is hardly new. Drying crops and grains by exposing them to the sun is a traditional agricultural practice.

Other examples of solar agricultural process heat applications include water distillation, livestock shelter heating, dairy water heating, on-site food processing, and greenhouse heating. The use of solar heat to distill and purify water was first used on a large scale in Las Salinas, Chile, in 1872. Essentially the same system is used for today's applications in small villages in the Mediterranean basin and the Caribbean. Greenhouse heating has always been a solar function. In certain climates, depending on the design and intended use of the greenhouse, it may require supplemental heating and cooling [1].

The sun's energy is already used on an experimental basis in France to power metal smelting furnaces. A megawatt furnace was completed in France in the 1970s. The furnace uses heliostats to direct sunlight toward a large parabolic concentrator. A similar 20-kW furnace began operating in Japan in 1963 [2]. In some instances industry is using solar systems to heat air and water and to produce steam.

\section{PRINCIPLE OF OPERATION}

Solar agricultural and industrial process heat systems collect the sun's radiant heat, convert that energy to sensible heat in a working fluid (air, water, or steam), and may store excess heat energy while distributing the sensible heat to a process application. The technologies used to collect this energy are not unique to the AIPH program. Generally, two classes of solar collectors, fixed and tracking concentrating (or hybrids of these systems), are used. The means for collecting the solar energy are dependent upon the end use temperature requirement. Agricultural process heat applications tend to require heat temperatures less than $212^{\circ} \mathrm{F}$. As such, fixed, nonconcentrating collector systems are used. Such collector systems include solar ponds, flat-plate and evacuatedtube collectors.

Industrial applications use low (less than $212^{\circ} \mathrm{F}$ ), intermediate $\left(212^{\circ} \mathrm{F}\right.$ to $350^{\circ} \mathrm{F}$ ), and high (above $350^{\circ} \mathrm{F}$ ) temperature solar energy collector technologies. Intermediate and high temperature systems generally use concentrating collectors, including compound parabolic, parabolic trough, parabolic dish, fixed and tracking segmented mirror tracking absorber collectors, and Fresnel lenses. For each of the sytems the heat collected by the collector is transported in a working fluid (air, water or steam) via a piping system to the end-use application. The heat of the working fluid is used directly, as in agricultural crop drying, or is transferred from the working fluid to the end use by a heat exchanger, as in certain industrial food processing system. 


\section{FEDERAL AGRICULTURAL AND INDUSTRIAL PROCESS HEAT PROGRAM}

The gaal of the Federal AIPH program is the substitution of solar for fossil fuelgenerated process heat. The objectives of the program are to:

- develop and demonstrate agricultural solar energy technology which could provide a substantial amount of heat energy for grain drying, crop drying, livestock shelter heating, greenhouse heating and cooling, and food processing; and

- apply state-of-the-art solar components and technology to industrial processes to dem onstrate their capability of supplying a significant amount of energy [3].

To meet these objectives the program is using solar technologies developed by the Solar Heating and Cooling and the Solar Thermal Power Systems prngrams. The AIPH program spans the four commercialization phases: (1) applied research, (2) development, (3) introduction, and (4) diffusion. Primary program emphasis is on experimentation, systems design, and prototype/demonstration stages. The focus of this program is not in basic hardware research, but rather in identifying and assessing the effectiveness of applying available equipment and improved cost-effective equipment in agriculture and industrial process heat environments.

Development projects originate in the Agriculture and Industrial Process Heat Branch of DOE's Conservation and Solar Applications Division. Management of this program in agricultural research projects has been assigned to the Agricultural Research Service (ARS) of the Department of Agriculture. ARS in turn works with state agricultural experiment stations, ARS laboratories, universities, and industry. Of 60 agriculture research projects listed in the 1977 AIPH Program Summary: 46 (77\%) were being done by universities, 8 (13\%) by USDA-ARS, 4 (7\%) by industry, and one by a government laboratory [3]

The industrial applications portion of the AIPH program is mannger by the Agricultural and Industrial Process Heat branch. The branch works with industry in the demonstration of solar thermal systems in industrial processes. Most of these projects are being done by contractors in the private sector.

\section{TECHNOLOGY RESEARCH STATUS}

In the development of this technology, efforts have been concentrated in demonstration projects and market research. The demonstration for specific applications are then followed by full-scale prototype system plants, with cost.s nften shared by the Federal Government and industry [3]. In the federally sponsored research projects underway attention is focused on:

- economic feasibility,

- technical feasibility,

- operating parameters (air flow rates, temperature, and humidity levels),

- energy efficiency,

- production efficiency (drying rates), and

- product quality. 
Numerous agricultural process heat projects and industrial process heat projects are using the low temperature (less than $212^{\circ} \mathrm{F}$ ) solar technologies such as flat-plate air and water systems, greenhouses, and passive design techniques. These systems are in the introduction and diffusion phases of commercialization. Industrial experiments with intermediate $\left(212^{\circ} \mathrm{F}\right.$ to $\left.350^{\circ} \mathrm{F}\right)$ process heat systems were started in the spirng of 1978; these systems are in the development stage with work concentrating on the prototype and pilot plant stages.

Several high temperature steam production demonstrations have been funded for conceptual design. Higher temperature process heat experiments are expected to start in the next few years. The equipment for these experiments are in the experimental and lab feasibility stages of the applied research phase [3].

\section{STANDARDS STATUS}

The installation and performance evaluation standards for AIPH systems are generally those that support the development of a particular solar technology. For example, the AIPH program will adopt the performance and safety criteria for solar heating and cooling systems developed by HUD, NBS, and the industry that are appropriate for AIPH applications [5].

In addition to installation and performance evaluation standards, the AIPH program is affected by environmental, health, and safety standards and regulations of EPA, OSHA, FDA, and USDA. Federal programs to assess environmental factors and standards applicable to AIPH projects are being performed or are planned [5] .

Federal Food and Drug Administration (FDA) and USD A food processing regulations have already affected the AIPH program. For example, an industrial hot water experiment at the Campbell Soup Company plant in Sacramento, California, had to comply with FDA regulations governing can washing [5].

Potential working fluid leakage or insufficient heating can result in chemical or microbial product contamination. No research has been done to date to assess the potential effects of such contamination in AIPH applications. To ensure that AIPH projccts comply with federal regullations and standards, studies are planned to assess the ability of the AIPH demonstrations to meet existing regulations. In addition, on-site monitoring and a strategy for improvement are planned for FY78-79 and will continue through the 1980s [5].

The success of solar technology in agricultural and industrial process heat applications depends on these standards-related activities. Product contamination is considered to have the greatest potential harm in agricultural and industrial food processing projects. If the system is economically and technicaly feasible but lacks safety, reliability, and quality control, neither food processing nor agricultural businesses will use solar energy technologies [5].

The national voluntary consensus standards system is supported by the Department of Commerce and the solar energy program offices in DOE as the appropriate framework for developing and implementing standards. However, most agricultural process heat experiments are occurring in federal laboratories or at universities, neither of which provides the industry representation essential to consensus. It is unlikely that a standards development and implementation program for agricultural process heat 
applications will be effective until an institutional framework for standard setting is developed.

\section{BUILDING CODES STATUS}

Building codes do not appear to present a barrier to solar energy use in agricultural and industrial process heat applications $[3,4,5]$. Standard and code provisions for solar heating and cooling systems are transferable to solar AIPH applications.

In some localities building codes may affect the construction of greenhouses connected to homes. To date, questions raised concern the retrofit of homes with greenhouses have been resolved through normal building code and permit channels $[6,7]$. 


\section{REFERENCES}

1. SERI, Annual Review of Solar Energy, Internal Draft (June 1978).

2. Williams, Richard J., Solar Energy Technology and Applications, Ann Arbor Science, Ann Arbor, Michigan (1977).

3. ERDA, Solar Energy for Agriculture and Industrial Process Heat Program Summary (June 1977).

4. ERDA, Survey of the Applications of Solar Thermal Energy Systems to Industrial Process Heat (January 1977).

5. DOE, Environmental Development Plan (EDP)-Solar Agricultural and Industrial Process Heat (March 1978).

6. Conversation with Bill Yanda, Director, State of New Mexico Solar sustenance Project (July 1978).

7. Conversation with Greg Franta, Senior Architectural Specialist, SERI (August 1978). 
TR-095

\section{SEP|}




\section{APPENDIX D \\ BIOMASS ENERGY CONVERSION SYSTEMS}

\section{HISTORY}

Biomass as an energy source is not new. Biomass, mostly in the form of wood, has been a source of heat from the beginning of time. Wood was the principal fuel in the United States until about 1900, when it was replaced by coal [1].

Outside the United States, small-scale units have been developed to convert biomass substrate to methane and carbon dioxide. Much of the effort began with the Gobar Gas Plant developed at the New Delhi, India, Agricultural Research Institute in 1939. China now has 500,000 small-scale digesters; India is installing about 100,000 new plants; and Korea is building 50,000 small-scale anaerobic units. Some small-scale digesters have been built on U.S. farms. These units generally produce only enough methane for one farm [2].

\section{PRINCIPLE OF OPERATION}

The conversion of biomass into usable energy of products involves a wide range of processes, the choice depending upon the substrate and the desired end product. The conversion process falls into two major categories: thermo-chemical conversion, and bioconversion.

Ther mochemical conversion uses heat to cause the decomposition of organic matter into other usable fuels. Gasification, liquefaction, and direct combustion are thermochemical conversion processes. In the gasification process, biomass such as forest residues are reacted with air or oxygen at an elevated temperature to produce gas. Liquefaction involves the reaction of the biomass material with oxygen and steam in the presence of a catalyst at elevated temperatures and pressures to produce heavy oils, gas and char [3].

Direct combustion converts biomass into usable heat rather than a secondary fuel. . If the biomass is dry enough, combustion can always be used and is applicable to manure as well as wood.

Bioconversion refers to biomass conversion processes accomplished through the natural activity of microorganisms, mainly bacteria and fungi. Bioconversion processes include: anaerobic digestion and fermentation.

Anaerobic digestion is a microbial process that proceeds in the absence of oxygen (anaerobic) and produces a mixture of methane and carbon dioxide. The most common use of anaerobic digestion in the United States is municipal sewage treatment. Methane is also generated through digestion of organic materials deposited in sanitary landfills. The gas may be trapped and used directly or, in a purified form, fed directly into existing natural gas pipelines. Animal manures are primary candidates for bioconversion by anaerobic digestion, but grasses, kelp, and microalgae are also considered possible substrates for large-scale methane production. 
Fermentation involves the conversion of sugars by yeast to ethanol and petrochemical substitutes. The breakdown of the cellulose fibers to sugar is accomplished by either acid or enzymatic hydrolysis.

\section{FEDERAL FUELS FROM BIOMASS PROGRAM}

The objective of the Fuels from Biomass (FFB) program managed by DOE is to develop the capability for converting renewable biomass resources into clean fuels, petrochemical substitutes, and other energy intensive products to supplement conventional fossil fuels. The major elements of the FFB program are the development of biomass sources, conversion processes, and market development of biomass products and fuels.

\section{TECHNOLOGY RESEARCH STATUS}

The status of biomass technology research depends upon the hinmass energy conversion technique under consideration. Research projects encompass the applied research, development, introduction, and diffusion phases of the commercialization process. Most federally funded research is being performed by national laboratories, universities, and private research companies. A very small percentage of the research is being performed by commercial development and marketing firms [3].

Research projects include feasibility studies, laboratory experimentation, pilot-plant construction, and demonstration projects. The biomass energy conversion systems offering the most potential for near-term commercialization are gasification and anaerobic digestion. Fermentation development is also under study. The enzyme process is undergoing pilot-plant trials and will be ready for demonstration by 1980 . The liquefaction process is a longer-term prospect for commercialization. While direct burning is important in the short term, it is evolutionary in its development and no technology breakthroughs are anticipated.

Standards development does not appear to be receiving any attention within the context of the biomass technology research program. There is a lack of active research on performance, test method, or environmental, health, and safety standards.

Specifically, data are not being generated in a systemic and formal manner that would contribute to standards development activities at a later date. Of equal importance is the lack of private commercial business participation in the research program. Without that institutional framework, voluntary consensus standards lag behind the technology development and may be a barrier for future commercialization activities.

\section{STATUS OF STANDARDS}

Except for existing environmental quality standards, equipment standards for the biomass technologies are generally not available.

There are some established standards and recent activity on the performance and safety of wood-burning appliances, including Underwriters Laboratory Proposal 1482. The Wood energy Institute sponsored the Wood Heating Seminar 3 in Madison, Wisconsin, in April 1978, and out of the seminar came a mandate for the institute and others to promulgate "Safety Standards for Wood Burning Appliances." Following a July 12, 1978 meeting, the 
draft standards were circulated to institute members and government agencies for review. There are also diverse state and local standards for these appliances.

For example, states adopting the 1977 revision of the BOCA Codes will allow only "listed" wood burning stoves to be sold in that state. A "listed" stove will be one that has been tested by an accredited laboratory such as Underwriters Laboratory(UL) or Sourthern Maine Vocational Technical Institute (SMVTI). The test in this case is for safety purposes only, but it may be expanded to include performance testing.

A principal barrier in the development of such standard test methods is the lack of "standards" or uniform wood substrate. Wood contains moisture in its natural state. Determining and standardizing the appropriate wood moisture content is a challenge to the program.

Environmental quality standards are normally promulgated by government agencies. Environmental quality standards usually are not voluntary consensus standards. The regulations have the effect of law, while the voluntary consensus standards do not unless they are referenced in a format that is legally binding. Environmental quality standards are mandated by the Environmental Protection Agency, the U.S. Department of Agriculturee, and the Department of Interior. Standards set by these agencies applicable to the biomass conversion processes affect water. and air quality, soil erosion, noise, and solid waste disposal.

Existing crop and forest residues are considered potential sources of energy. Extensive removal of these residues could allow water and wind erosion at a greater rate than that recommended in the guidelines of the USDA-Solid Conversion Service. There may also be state soil conservation guidelines. The same is true of high rates of soil erosion possible if entensive cultivation is used in energy plantations.

Increased particulates in the air may result from crop residue removal, intensively cultivated energy plantations, or increased wood or other biomass burning in power plants and homes. Standards for ambient air quality and for performance of new stationary sources were promulgated by the USEPA under authority of the Clean Air Amendments of 1970. State and local authorities must abide by the minimum federal standards but may set more stringent local standards.

The starting point for water quality standards is the Federal Water Pollution Control Act (FWPCA) Amendments of 1972. Standards for effuent limitations and performance were authorized under the Act and enforcement authority was given to the EPA. Covered under the Act are potential runoffs or discharges from biomass operations. Examples are sewage sludge and toxic substances posing health hazards. The Act grants authority to promulgate standards mainly for point sources, excluding most agricultural operations. However, the FWPCA of 1972 specifically covers concentrated animal feeding operations- $a$ frequently mentioned source of biomass for on-site anaerobic digestion. Nonpoint sources and groundwater quality are left to state and local regulations, and standards from these agencies may be applicable to biomass operations. State and local authorities may also issue more stringent standards.

A multitude of federal, state, and local standards would be applicable to agricultural and silvicultural practices used in biomass production and conversion. These include regulated practices such as harvesting, road construction, reforestation, use of chemicals and fertilizers, slash disposal storage, clearcutting, streambed activity, and many others. 
Ocean farming and the attendant development of on-site or coastal processing sites would involve activities affected by federal, state, and local standards. The key federal statute is the Marine Protection, Research, and Sanctuaries Act of 1972, popularly known as the Ocean Dumping Act. There is also some overlap with authority under the FW PCA and some confusion about the setting of standards under the two Acts. Important considerations are the technology-based "best practicable" and "best available" standards under FWPCA, which EPA also writes into the permit issuance proncedure under the Ocean Dumping Act. This could be an important consideration in the flexibility of standards with new technologies. The Ocean Dumping Act has.generally been interpreted as having a strong national and international flavor, and the state and local role in this area is not well established.

Some biomass technology equipment, such as shredders for municipal forestry wastes, could exceed noise standards. Federal guidelines are set by the EPA under the Noise Control Act of 1972. State and local standards may be more stringent and be made to apply to such equipment.

Under the National Environmental Policy Act of 1969, far-reaching and diverse standards could affect the development of the biomass technologies. These standards are too extensive to be discussed here, but examples are the guidelines for developing environmental impact statements and the Act's mandate to other federal agencies to consider environmental quality.

Guidelines and codes relating to solid waste management could be applicable to several facets of biomass technologies, particularly recovery of energy products from municipal solid wastes and agricultural wastes. The Federal Resnurce Conservation and Recovery Act (RCRA) of 1976 has the potential for far-ranging impacts on these technologies in the form of standards and model codes. In several sections the Act recognizes the potential for energy recovery from solid waste. The EPA is authorized to publish a multitude of guidelines affecting federal agency use of recovered products, including energy products. Standards are also set for solid waste management plans (including the energy element) to qualify state and local areas for federal funds. The EPA is also authorized to recommend model codes for solid waste management. Section 6952 of RCKA authorizes the Secretary of Commerce to act through the National Bureau of Standards and, in conjuction with national standards-setting organizations in resource recovery, to publish guidelines for developing specifications for classifying materials recovered from waste. The specifications are to refer to physical and chemical properties in replacing virgin materials for various industrial, commercial, and government uses. These standards would be directly applicable to fuel pellets derived from municipal and forestry wastes.

\section{BUILDNG CODE STATUS}

Except for wood burning appliances, building codes do not specifically address the construction or operation of biomass energy conversion technologies.

In most areas building codes cover the installation of wood burning appliances, requiring certain clearance from walls and floors and certain venting procedures and types of pipes. The Uniform Building Code (Chapter 37) sets requirements and the National Fire Protection Association Code also covers such installation. The proposal from the Wood Energy Institute will include building code recommendations. 
Existing code provisions for plumbing, electrical connections, structure support, etc., are applicable to biomass energy conversion applications. There appear to be no case histories where biomass conversion systems were denied building or operation permits due to conflicts with building codes. The possible use by homeowners of small digestion units could potentially confront building code barriers for the installation of the unit and systems for using the gas. 


\section{SझP|繁}




\section{REFERENCES}

1. SERI, Annual Review of Solar Energy, SERI/TR-54-066 (November 1978).

2. Varani, Frederick T., and Burford, John J., "The Conversion of Feedlot Wastes into Pipeline Gas," Fuels from Wastes, Academic Press, Inc., San Francisco (1977).

3. DOE, Fuels from Biomass Program-Program Summary (January 1978). 


\section{APPENDIX E}

\section{WIND ENERGY CONVERSION SYSTEMS}

\section{HISTORY}

Wind energy conversion systems, primarily for water pumping, have been used extensively in this country since the $1850 \mathrm{~s}$. Six million small machines $(1 \mathrm{~kW})$ were operating around the turn of the century. Of these approximately 150,000 are still in use today [1]. Some research and experimentation with large wind machines (defined in this report as $100 \mathrm{~kW}$ or larger) were conducted in the United States in the 1930s and 1940s. Between 1941 and 1945 the largest wind machine ever built to generate electricity, the Smith-Putnam 1.25-MW unit, was installed in Vermont to deliver utility power. In 1945 a blade broke and could not be repaired due to wartime material shortages. While large wind machines were used in other countries during the 1950s and 1960s, interest in the United States generally declined. The Rural Electrification Act of 1936 and the shortage of material for blade construction during World War II contributed to the decline in use.

\section{PRINCIPLE OF OPERATION}

There are several wind energy conversion system designs. The main component of all designs is the rotor, which is turned by the windstream to transform the power of the windstream into mechanical power. The transmission system is responsible for transmitting the mechanical power from the rotor to a point at which it may be used either in mechanical form or to produce electrical energy [2].

The two main designs of wind energy collectors are classified by the orientation of their axis of rotation relative to the windstream. These designs are horizontal-axis wind turnbines (HAWT)-the axis of rotation is paralled to the windstream-and vertical-axis wind turbines (VAWT)-the axis of rotation is paralled to the windstream-and verticalaxis wind turbine (VAWT)-the axis of rotation is perpendicular to the windstream. (See Figure 1).

The basic design for a HAWT consists of the rotor (blades, hub, pitch change mechanism); drive train (shaft, speed increaser, generator); nacelle (shroud, bedplate, gear mechanis m); tower; and electrical and control system. Most large horizontal-axis wind turbines manufactured today are of the two- and three-blade design as opposed to multiblade design. The wind machine blades catch the wind either in front of the tower (upwind rotors, Figure 1, Id) or in back of the tower (downwind rotors, Figure 1, Ie). Most turbines have a yaw mechanism to orient the machine into the wind, and most turbines rotate on the tower in order to "track" the changing direction of the wind. Beyond the "rated" wind speed the generator is incapable of absorbing the energy removed by the rotors from the windstream. The extra energy is usually spilled by feathering the blades to an unloaded condition (rotating the bldes into a stalled condition) or by turning the rotor sideways. Almost all machines are designed with a safety mechanism to stop the blades at a designated "cut out" wind speed.

The VAWT design incorporates the blades, tower, guy.wires, transmission, generator, and controls into one unit. One type of VAWT is the Darrieus rotor with curved blades and airfoil cross sections (Figure 1, $\mathrm{Ia}, \mathrm{b}$ ). Another vertical-axis design is the Savonius Sshaped cross section rotor (Figure 1, Ile, d). 


\section{THE FEDERAL WIND ENERGY PROGRAM}

The Federal Wind Energy Program (FWEP) was initiated in FY74 under the auspices of the National Science Foundation (NSF) [2] and funding for the program has grown rapidly. The FY78 budget was approximately $\$ 35$ million. The objective of the Federal Wind Energy Program (FWEP) is to accelerate the development of reliable and economically viable wind energy systems capable of providing up to 30 years of relatively maintenance free service. To accomplish this objective, the FWEP is organized into five major program elements [3].

- program development and technology (research)

* mission analysis

* application of wind energy

* legal/social/environmental issues

* wind cliarueleristles

* technology development

* advanced and innovative concepts

- farm and rural (small) systems

- $100 \mathrm{~kW}$-scale systems

- MW-scale systems

- large-scale multiunit system (utility-grid arrays)

Data and information for the development of WECS standards are supported primarily by work in program development and technology research and the farm and rural use (small systems) program element. Contracts have been awarded by DOE to Rocky Flats, WECS manufacturing firms, and research companies such as Jet Propulsion Laboratories, BoozAllen and Hamilton, Inc., and Charles stark Uraper Laboratory to support standards development.

\section{TECHNOLOGY RESEARCH STATUS}

Research for large wind energy conversion systems is in the development phase with program efforts focusing on the fabrication of "breadboard models" and prototypes. Small wind machine research is in the development and introduction phase of the commercialization process. Performance testing and evaluation programs are being conducted for small wind machines.

Technical research in the future will concentrate on continued field testing of experimental wind systems in user environments. For components and subsystems increased emphasis will be on developing and testing low cost, light-weight rotors and hubs to reduce manufacturing costs, increase service life, and decrease maintenance. For large systems research is expected to lead to the design of 10 to $100-\mathrm{MW}$ unit pilot plants. Such efforts in the early 1980s would contribute to determining the economic feasibility of utility-based wind power. Also, wind characterization research will focus on the continued development of models that allow the cost effective selection of single and multiunit sites. 
Nontechnical research will focus on additional marketing and economic incentive studies for small wind systems. Remote and isolated area markets appear to offer the earliest potential market for WECS. Small WECS (less than $100 \mathrm{~kW}$ ) are prime candidates for providing power in dispersed application such as [2].

- rural electrical generation with storage and a synchronous inverter (for converting $\mathrm{DC}$ to $\mathrm{AC}$ ),

- irrigation pumping, and

- remote electrical generation to replace on-site diesel fuel generation [8].

\section{STANDARDS STATUS}

Voluntary consensus standards or federal standards do not exist for wind energy conversion. Industry performance and materials specifications exist for many of the components used in the wind energy conversion system (WECS). Several recent reports have underlined the need for performance, reliability, safety, and life expectancy standards for WECS $[4,5,6]$. The development of such standards has several unique problems. WECS do not operate under uniform conditions because the wind is not constant in speed or direction. Thus the determination of standard test conditions is difficult. Further, accurately simulating the test conditions may be a problem. Wind energy conversion machines with the same blade diameter may be rated for different wind speeds and rated outputs depending upon the complete system design and intended end use. The performance evaluation of a given WECS is thus dependent upon its intended use, not simply the machine.

The issue of standards, testing, and nomenclature was addressed during the second workshop on WECS in Washington D.C., June 8-11, 1975. The topic was the focus of one of eight working groups at the conference. Principal concerns of the working groups were:

- The lack of consistency in terms used to describe wind machines. Designations used to describe machines that extract energy from the wind may influence public acceptance and communications. The group recommended definitions for general and engineering terms and discouraged such terms as small-scale system and large-scale system.

- The lack of testing standards. Until such standards are available, it was recommended that full disclosure of testing conditions be provided.

- Testing guidelines need to be developed. The American Wind Energy Association (AWEA) offered to develop such guidelines for smaller systems, and the workshop group suggested that ERDA review them. It was further expected that NASALew is would develop testing guidelines for larger systems.

- Design standards are needed. The American Heliocopter Society (AHS) expressed interest in this task through a wind turbine subcommittee under their design committee [12].

These discussions occurred several years ago. Although there are still no performance or quality standards for WECS [8], there appears to be a renewed and more agressive interest in developing them. According to the AWEA, as of February 1978, "Standards development is perhaps the most important issue facing the industry. It is imperative that all concerned learn as much about the subject as possible." (The AWEA was formed 
in 1974 to promote wind energy implementation and utilization, to foster technical excellence, and to work toward solving the social, legal, and constitutional issues of wind energy conversion.)

AWEA has developed a plan for such a program [9] with four major elements: (1) terminology, (2) standard performance data, (3) testing procedures, and (4) standard development guidelines. Establishing an advisory board representing consumers, manufacturers, and distributors; standards organizations; and general interests is part of the development plan. The plan is based on the voluntary consensus system.

The plan proposed by AWEA under contract to Rocky Flats is a long-term effort. Meanwhile, there is an urgent need for some interim standards to respond to three laws passed by the U.S. House of Representative as of February 1978, relating to tax credit legislation contained in the National Energy Act. One law requires that a wind energy conversion machine have a five-year life. The second reguiras that machine use begin with the owner, which would eliminate used machines from the tax credit legislation. The third is that WECS comply with existing performance and quality standards.

To meet these needs, the AWEA has made three recommendations:

- AWEA should take primary responsibility in the development of standards for large and small WECS,

- Total system cost should be the basis of the tax eredit, and

- Any criteria (performance) suggested to the Department of the Treasury or IRS should be flexible.

Other factors necessitate the development of standards. Manufacturers need standards so that their machines can be understood by consumers. Federal, state, and local municipalities need standards in the purchase of WECS for public programs, as well as for building code implementation. A federal demonstration program is currently undel consideration that will need standards for purchase and installation. In addition, consumers need standards not only for information but also for consumer protection.

It is not realistic to anticipate that standards will be developed for WECS in the near term. There are too many unanswered questions that can only be answered by equipment testing. For example:

- There is insufficient information on applied loads and wind site turbulence; and

- An applied local needs to be defined, as do structural load or wind loading on the rotor.

The AWEA has proposed to DOE a \$1 million FY79 budget for developing WECS standards/codes. This budget is part of a large sum, $\$ 2.15$ million, for legal, social, and environmental issues. Currently, the Office of Management and Budget has allocated $\$ 150,000$ for all such studies [6].

In the WECS program planning and summary documents reviewed $[3,4,10]$, a program for developing WECS standards and codes was not defined. Funding may be occurring under technology development and testing programs. However, standard and code development acitivities do not currently have the visibility in DOE of site assessments or prototype test studies [6]. 
System performance and evaluation standards are not the only ones which potentially affect the commercialization of WECS. As shown in Table 1, numerous federal agencies currently set standards addressing the construction and operation for WECS. Programs have begun to review and identify the impact of these standards, especially safety procedures and regulations for WECS, and to assess the need for standards and regulatory modifications to address WECS adequately [10]. Such programs are being performed by national laboratories, private research firms, and WECS manufacturing firms. In addition, the DOE program office has identified the following organizations to help support standard development and modification programs:

- National Institute of Occupational Safety and Health

- National Institute of Environmental Health Sciences

- National Bureau of Standards

- American Wind Energy Association

- Underwriters Laboratories

- American National Standards Institute

\section{BULDNG CODE STATUS}

Based on the available data it does not appear that codes specifically address the installation of WECS. There are no precedents for installation of wind machines on buildings or property. It has been projected [10] that height and roofload limits may deny WECS applications. In addition to structural safety codes, state and local governments may impose land use regulations [11]. Further, the potential effect of codes on WECS applications depends primarily on the population density of the site. Building codes tend to be more restrictive and defined and more strictly enforced in high density urban areas. As there are no guidelines, building inspectors may be reluctant to approve WECS, especially in the densely populated areas.

At the Third Wind Energy Workshop in September 1977, members of the institutional barriers working group felt that the most important barrier to WECS growth was building codes [12]. The group's ranking of potential barriers was:

- building codes;

- product liabllity;

- central, distributed, and the utility interface;

- rate structure;

- zoning; and

- finances.

Building, safety, and housing codes may not effect a total prohibition of WECS use. However, compliance with their requirements may impose substantial burdens on the WECS sponsor [13]. Technical justification, equipment performance data, engineering and architectural signoffs, site visits, and presentations to the building code agency not normally required for building constuction may result in significant time and cost increases for the intended installation. 
The Third Wind Energy Workshop, September 1977, recommended that a model wind code might be developed to resolve this issue. More specifically, the development of standards for small wind systems and an educational program for building inspectors was encouraged.

Numerous research projects have been done or are planned to address WECS issues which affect standard and code development efforts for WECS [10]. These projects will identify:

- issues of design, fabrication, installation testing, and operation;

- existing safety regulations that may apply to WECS and needed modifications, if any; and

- need to establish safety guidelines.

The projects will provide information critical to establishing provisions in building codes to cover the codes' responsibility for consumers' health, safety, and welfare. 
Table 1. STANDARD SETTING FEDERAL AGENCIES FOR WECS

\begin{tabular}{|c|c|}
\hline Agency & $\begin{array}{c}\text { Standard for } \\
\text { Height and Safety }\end{array}$ \\
\hline $\begin{array}{r}\text { Occupational Safety and Health } \\
\text { Administration }\end{array}$ & $\begin{array}{l}\text { Standards for materials, } \\
\text { equipment, and workplace }\end{array}$ \\
\hline Federal Power Commission & Utility \\
\hline Federal Communications Commission & Radio/TV interference \\
\hline Federal Aviation Administration & Height \\
\hline U.S. Coast Guard & Siting \\
\hline Environmental Protection Agency & Noise, Enviromental Impact \\
\hline
\end{tabular}

Source: Legal Institutional Implications of Wind Energy Conversion prepared by. Program of Policy Studies in Science and Technology, George Washing ton University, for DOE, September 1977. 


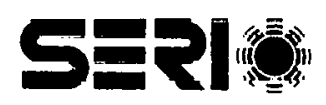




\section{REPERENCES}

1. MITRE Corporation, Preliminary Wind Energy Commercialization Program (November 1976).

2. SERI, Economic Feasibility and Market Readiness of Solar Technologies, SERI/TR52-055, Draft Final Report (September 1978).

3. DOE, Federal Wind Energy Program-Program Summary (January 1978).

4. General Electric Company, Wind Energy Mission Analysis-Executive Summary, prepared for ERDA (February 1977).

5. Tennyson, George, "Test and Product Standards for WECS." AWEA Newsletter (Summer 1977).

6. American Wind Energy Association, the Federal Wind Program: A Proposal for FY79 Budget, prepared for DOE (February 1978).

7. Wilson, Robert E., Proceedings of the Second Workshop on Wind Energy Conversion Systems, "Standards, Testing, and Nomenclature," NSF-RA-N-75-050, NASA (June 1975).

8. Wolf, Ben, "Standards and Testing of WECS," Third Wind Energy Worshop, edited by JBF and ERDA (September 1977).

9. Mayer, Don, "Standards for Wind Systems, AWEA Newsletter (February 1978).

10. ERDA, Solar Program Assessment: Environmental Factors-Wind Energy Conservation (March 1977).

11. Development Plan, Wind Energy Conversion, CSA/EV/DOE, Washington, D.C. (March 1978).

12. Johanson, Edward, "Institutional Barriers to WECS Growth," Third Wind Energy Workshop (September 1977).

13. Legal-Institutional Implications of Wind Energy Conversion Systems, prepared by Program of Policy Studies in Science and Technology, George Washington University, for NSF (September 1977). 


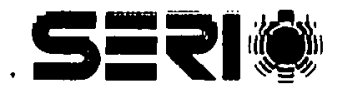




\section{APPENDIX F}

\section{PHOTOVOLTAICS}

\section{HISTORY}

Photovoltaic research began with the discovery of selenium in the early $1880 \mathrm{~s}$. The photovoltaic effect was observed in this substance, leading to the development of the selenium cell. In 1941 the first single crystal silicon cell was developed. After twelve years of research, conversion efficiencies of $6 \%$ were achieved. Manufacture of single crystal silicon cells began the following year [1]. Solar photovoltaic conversion systems employing these cells were first used extensively in the U.S. space program for electrical power in satellites in the 1960s. The largest systems had a capacity of $10 \mathrm{~kW}$. The basic photovoltaic conversion technology has been proven, and terrestrial applications of solar photovoltaic systems already exist [2].

\section{PRINCIPLE OF OPERATION}

The photovoltaic effect occurs when sunlight is directly converted to electricity through the excitation of electrons (negative carriers) or holes (positive carriers) by absorption of light, which permits current flow through some type of semiconductor material. This material acts as a conductor only in the presence of sufficient heat or light. (In dark- or low-temperature conditions, the material does not conduct.) When light of the appropriate wave-length and sufficient energy hits the semiconductor material, it frees the electrons from their chemical bonds. When the freed electrons move, this creates a hole that is also capable of moving. The movement of the electrons and holes creates a voltage. Contracts placed in front and in back of the solar cells enable the cell's electric current to flow to an external circuit.

The major components of a photovoltaic system are the solar collector module, a storage system (batteries), and a power conditioning unit. These components work together as follows. Sunlight hitting the solar collector, composed of solar cells, is converted to electric energy and transmitted to the storage system as DC electricity. The power conditioning unit prevents the overcharging of the batteries and, where required, converts DC electricity to AC.

\section{FEDERAL PHOTOVOLTAIC PROGRAM}

Major federal funding for photovoltaic research, development, and demonstration programs started under the NASA program. Funding for photovoltaic space applications research continues at NASA-Lewis, NASA-,Marshall, the Jet Propulsion Laboratory (JPL), and other prime contractors to the federal government. Federal funding for terrestrial research programs is managed by the Photovoltaic Energy Conversion Branch in the DOE's Division of Solar Technology. Program support is provided by contracts with federal laboratories, universities, and private business [3].

The overall objective of the photovoltaic program is to ensure that photovoltaic conversion systems provide approximately $\mathbf{5 0}$ gigawatts electric generating capacity to the nation by the year 2000. To achieve this goal, the federal program is focusing on reducing the peak watt price of photovoltaic electricity. Price goals are to achieve $\$ 1$ - 
2/peak watt prices at an annual production rate of 20 peak megawatts in 1982; $\$ 0.50$ /peak watt at an annual production rate of 500 peak megawatts in $1986 ; \$ 0.10$ to $\$ 0.30$ /peak watt in 1990; and an annual production rate of 50 peak gigawatts in the year 2000 .

The photovoltaic program is committed to:

- improving the efficiency of cells,

- reducing the cost of manufacturing processes,

- obtaining large scale operating experience in photovoltaic system applications,

- coordinating with the storage technology program to augment photovoltaic system operations, and

- improving cell and array reliability and lifetime.

The objectives of the program are being accomplished through:

- research and advanced development,

- tests and applications,

- systems support,

- technology development,

- standards and performance criteria, and

- program management and analysis [2].

The photovoltaic program is supporting the development of system standards together with further technology research and development.

\section{TECHNOL̄OGY RËSEARCH STATUS}

Photovoltaic technology is in the development phase for residential and commercial applications and in the diffusion stage for remote and space applications.

Prime projects for development are the Low-Cost Silicon Solar Array Project (LSSA), concentrator systems research, and advanced develnpment. The I.SSA projert, managed by JPL, is aimed at developing the technical and industrial capability to produce lowcost, long-life arrays. Efforts are concentrated in the design, fabrication, and test states. Concentrator system research at Sandia Laboratories includes the develnpment. solar cells optimized for operation at higher concentration levels. There is a concentrated effort in research of materials, particularly thin films. Attention is being given to the evaluation of long-term cell efficiency, degradation, physics, and chemistry of fabrication characteristics [2]. SERI assumed full responsibility for the Advanced Materials Research and Development Program in October 1978. Research is also heing conducted through parallel, competitive award efforts by industry.

Three materials are currently used for solar cells. Silicon is the major one used by about ten producers in current manufacturing. Cadmium sulfide and gallium arsenide are used primarily in research. The materials vary in efficiencies (in laboratory tests); single crystal silicon has an efficiency as high as $18 \%$, single crystal gallium arsenide somewhat higher, and thin-film cadmium sulfide about $9 \%$. 
Production costs include time-consuming and expensive cell production factors, as well as assembly and installation costs. Silicon, for example, has to be cleansed of all impurities and then carefully cut. The Czochralski technique, most widely used now, and the Edge-Defined Film-Fed Growth (EFG) technique currently being researched are delicate processes involving a high percentage of material waste and capital equipment costs. Only with the Czochralski technique has automated production begun. The labor cost reduction achieved by automated manufacture will contribute greatly to the goal of reduced peak watt cost. Thus, research in assembly and production techniques is a important to the achievement of lower costs as technology and materials research efforts.

\section{STANDARDS STATUS}

The standards and performance criteria effort in the federal photovoltaic program was begun in early FY78. The four major task areas are:

- development and publishing of solar photovoltaic conversion system, subsystem, and component performance and lifetime criteria and test methodology;

- the establishment of standards and procedures for testing performance and lif etimes of conversion systems, subsystems, and components;

- support in identifying and certifying testing laboratories qualified to conduct photovoltaic performance and lifetime tests; and

- providing assistance in the writing of building code provisions applicable to photovoltaies.

The responsibility for initiating and coordinating programs to accomplish these tasks has been assigned to SERI. The FY79 goals of the Quality Assurance and Standards Program within SERI include:

- development of an interim performance criteria document to identify performance characteristics together with the appropriate test methodology for measuring them;

- development of identifying procedures for laboratory accreditation and project certification;

- development of a program for validation of test methodologies; and

- interaction with the voluntary consensus standards community [4].

To reach these goals, SERI will continue management of a project begun in FY78-the Coordinating Council for the Development of Performance Criteria and Test Methodology for Photovoltaics. The Council is comprised of representatives from the government laboratories, manufacturers, standards developing organizations, trade associations, public interest groups, DOE, and SERI.

The council has:

- defined the PV subsystems hierarchy for flat-plate and concentrator systems,

- defined component terme,

- identified performance criteria to be measured, 
- identified the status of test methods for performance criteria measurement and the organizations undertaking the research,

- established subcommittees to address reliability, durability, safety, storage, and power conditioning and control, and

- established a subcommittee to design strategies for standards development and implementation.

The council will interact with the American Society of Testing and Materials (ASTM) subcommittee E-44 on solar energy conversion. It is planned that elements of the interim performance criteria document developed by SERI will be transferred to the voluntary consensus community for further development as an American National Standards.

In $^{-}$June of 1978, ASTM committee E-44 established a subcommittee (E-44.09) on photovoltaics. Three methods for testing characterics of flat-plate photovoltaic collectors are being drafted at the task group level [5].

SEIA, the Solar Energy Industry Association, organized a photovoltaic standards committee in December of 1977 to develop industry-sponsored standards with government aid rather than government direction [6]. The committee will address four standards areas: safety testing, performance, reliability testing, and rating and certification. There have been no published results to date.

The American National Standards Institute (ANSI) sponsors a Steering Committee on Solar Standards that coordinates the development of standards for solar heating and cooling systems. The committee votes in November 1978 to expand its scope to include photovoltaics and will assume an oversight function for photovoltaic standard development, including the identification of existing standards, the identification of priorities, and assignment of responsibility for developing voluntary consensus standards.

The Institute of Electrical and Electronics Engineers (IEEE), another ANSI member which produces voluntary consensus standards, has several technical committees addressing photovoltaics, particularly in the area of storage and in power conditioning, control, and cabling.

The National Bureau of Standards is a major force in developing and verifying test methodologies. The groups in the solar technology and the semiconductor research divisions are active members in the standards development process. As the research and testing arm of the federal government, they are working in conjunction with the SERIsponsored Coordinating Council.

The military has developed specifications for purchase of photovoltaics. This effort is rudimentary and is subject to modification as additional research developments occur.

The major emphasis of the standards development activities is to ensure that industry consensus standards are available to guide new entries into the photovoltaics market in the early 1980 s. 


\section{BUILDNG CODE STATUS}

At present, building codes are not a critical consideration in the use of photovoltaic energy conversion systems. Photovoltaics are used sparingly in remote applications. The 1977 world production of photovoltaics was about 750 peak $\mathrm{kW}$. Thus building codes do not specificially address the use of photovoltaic energy conversion systems, and building code officials have not been required to approve the use of photovoltaics in residential or commercial applications.

A subcontract was awarded in the summer of 1978 by JPL to the architectural firm of Burt, Hill, Kosan and Rittleman [7] to address the relationship between photovoltaic applications and building codes. Electrical areas such as local frequency, wiring, cycling, switching, storage, and integration with conventional hookups will be reviewed relative to the requirement of the National Electric Code (NEC) of the National Fire Protection Association (NFPA). Durability and reliability questions, such as roof loading, will also be addressed.

It is anticipated that efforts in developing building code provisions will be limited until the technology achieves a more stable state of development and until standards evolve. 
TR-095

\section{SEProf}




\section{REFERENCES}

1. SERI, Economic Feasibility and Market Readiness of Eight Solar Technologies (Interim Draft Report) (June 1978).

2. DOE, National Photovoltaic Program Plan (March 1978).

3. DOE, Analysis of Small Business Participation in the Photovoltaic Area of Solar Technology (April 1978).

4. SERI, PV Quality Assurance and Standards Program Plan (1978).

5. Minutes of the Meetings of ASTM E-44, June 13 to 15, Philadelphia, PA.

6. SEIA Newsletter of $2 / 78$, SEIA, Washington, D.C., p.2.

7. Announcement made at the JPL-Project Integration Meeting, Caltech, August 16, 1978, Pasadena, California. 


\section{SEPI影}




\section{APPENDIX G \\ SOLAR THERMAL ELECTRIC POWER SYSTEMS}

\section{HISTORY}

Solar thermal electric power systems (STEPS) convert solar energy into electricity by collecting, concentrating, and converting the sun's ray to heat and then to electricity by means of a heat engine or a thermodynamic (Rankine, Brayton, Stirling) conversion plant. Between World War I and World War II an experimental solar thermal power system was built in Egypt that converted sunlight to electricity with an overall efficiency of nearly 20\%. Giovanni Francia of the University of Genoa built a solar thermal system in 1966 that achieved a thermal collection efficiency of $60 \%$. Research to improve STEPS efficiency is continuing today in the United States and other countries [1].

\section{PRINCIPLE OF OPERATION}

There are two ways in which solar electric thermal power systems are applied: in central power applications and in dispersed power applications. An example of the central power application is a large field of two-axis tracking heliostats (or mirrors) that concentrate solar energy on a tower-mounted receiver. A heat transfer fluid circulates through the receiver and carries heat energy to an energy conversion system. Storage may be included for backup or peak demand requirements. Centralized power applications $\left(10+\mathrm{MW}_{\mathrm{e}}\right)$ are designed for use in utility networks.

Dispersed power applications usually use systems that collect sunlight on separate collector modules. Each collector module has its own absorber (receiver) where solar energy is converted to thermal energy. Thermal energy at each collector can be transported by a working fluid such as steam or hot water to a central location for electricity generation. Alternatively, thermal energy can be converted through a chemical reaction and the reaction reversed at a central plant. Thermal energy at each collector can also be converted to electricity by heat engine-generator units on or near the collectors. Distributed collector solar thermal power systems may also have storage subsystems: either thermal (latent or sensible heat storage) or nonthermal (mechanical, electrical, or chemical storage) [1].

The different types of solar collectors that can be used for dispersed systems include flat-plates, parabolic troughs, paraboloidal dishes, and even small versions of the central receiver. Flat-plate systems have the lowest collection efficiencies and the lowest temperature capability $\left(140\right.$ to $\left.200^{\circ} \mathrm{F}\right)$. Temperatures are typically 400 to $800^{\circ} \mathrm{F}$ for oneaxis, tracking parabolic trough systems and in excess of $1000^{\circ} \mathrm{F}$ for two-axis, tracking paraboloidal dish systems.

Three types of systems have been identified for near-term dispersed power applications: (1) small ( 1 to $10 \mathrm{MW}_{e}$ ) solar thermal power plants; (2) solar total energy systems; and (3) irrigation pumping systems. The small solar thermal power plant is projected for use in municipally owned power systems or rural electric cooperatives. Line-focusing and point-focusing subsystems would probably be used for these applications. Solar total energy systems are designed to use the thermal energy rejected from the electricity generating subsystem. This system is being considered for applications that have electrical and heating requirements matching the capacity of the system. 
It is anticipated that one-axis tracking parabolic trough collectors will generally be used in total energy systems because they appear to be easier to integrate into current building designs. Other types of concentrating collectors and small central receiver systems may be used. The choice of technology is dependent on the power and heat requirement, economics, site, and other factors.

Irrigation pumping systems (under $500 \mathrm{~kW}$ ) are being developed to replace traditionally fueled irrigation pumps with those powered by solar energy. Parabolic trough collectors, parabolic dish, and small central receiver systems are being considered for this application. The dispersed collector is coupled with an appropriate heat engine or power cycle to drive the electrical pump.

\section{FEDERAL SOLAR THERMAL ELECTRIC POWER SYSTEMS PROGRAM}

A federal program for solar thermal electric power research started in 1970 at the NSF with a budget of $\$ 100,000$. The program was transferred to ERDA in 1974 with a congressional authorization and budget of $\$ 20$ million. The DOE inherited the solar thermal electric power program in 1977. The FY78 budget is $\$ 60.1$ million [2]

The objective of the federal Solar Thermal Electric Power program is to achieve public utilitzation of solar thermal technology for dispersed (1980s) and central (late 1980s) applications [2].

The three program elements designed to meet this objective are central power plant, dispersed power plant, and advanced technology development. Major program emphasis is on central power applications. The design, fabrication, and testing of subsystems for a $5 \mathrm{MW}_{\mathrm{f}}$ solar thermal electric power system, which is the forerunner of a $10 \mathrm{MW}$ system experiment (Barstow) and a $100 \mathrm{MW}_{\mathrm{e}}$ prototype module are currently underway. Additional program goals are to:

- design high performance heliostat and concentrator units appropriate for mass production by 1979 ,

- develop $1770^{\circ} \mathrm{F}$ receivers by 1980 and $2000^{\circ} \mathrm{F}$ by 1985 ,

- develop low-cost durable thermal storage systems, and

- develop low-cost operation and maintenance techniques by 1980 [3] .

The responsibility for the Solar Thermal Power Systems Program lies with the Solar, Geothermal and Advanced Energy System Office under the Assistant Secretary for Energy Technology.

\section{TECHNOLOGY RESEARCH STATUS}

Central application technology research is primarily in the applied research phase (design concept and experimentation). Design studies are being started on advanced, second generation power plants and subsystems. The system design for a $10 \mathrm{MW}$ demonstration plant (Barstow) to be constructed in California has been selected. Testing and operation are scheduled to start in FY81. A $5 \mathrm{MW}_{\mathrm{e}}$ test facility at Sandia Laboratories in New Mexico began operations in FY78. 
Dispersed applications research is in the engineering development phase. Program efforts are focusing on system design and fabrication and on engineering test and evaluation. A 25-hp irrigation facility became operational at Willard, N.M., in FY77. A $1 \mathrm{MW}_{\mathrm{e}}$ small community power system program was started in FY78, with principal attention given to system design and definition. The design for the Shenandoah, Ga., total energy system experimental project was completed in early 1978 and construction started in August 1978. This project will provide electricity, hot water, heating, cooling, and industrial process steam for the Bleyle Kurtware Manufacturing Plant. The project is scheduled for completion in early 1981. Its cost is shared with DOE by the Georgia Power Company.

The advanced technology program includes defining and developing long-range power plants, concept definition and evaluation, system studies, and large-scale experimentation for alternate equipment designs [4]. This program focuses on concept feasibility analysis and evaluation. The advanced technology systems program is in the early stages of applied research.

\section{STANDARDS STATUS}

Except for standards developed for flat-plate collectors, there are no voluntary consensus standards for other components and subsystems for solar thermal electric power applications. DOE program plans indicate performance criteria will be developed and adopted for solar total energy systems and promulgated as federal standards $[5,6]$. A program for materials testing in support of the structural design of solar energy central receiver power plant components was started in FY77. Argonne National Laboratory will work with Sandia Laboratories and Foster-Wheeler, a private consulting firm, to identify materials and test conditions for mechanical properties testing in support of the American Society of Mechanical Engineers (ASME) code development activities for central receivers. Foster-Wheeler is also under contract with DOE to develop structural design standards for solar central receivers and components. This effort is examining failure modes and rates to develop reliability standards for the system. Reliability, availability, and safety levels desired in central receiver solar thermal electric power system components will be defined. Foster-Wheeler is using the ASME Boilers and Pressure Vessel Code as the starting point in developing provisions, standards, and codes for the colar central receiver solar program.

Additional materials standards work is being done by Battelle-Pacific North-west Laboratories. The project is aimed at drafting standards and developing measurement techniques for use by the solar industry for quality assurance (QA) and for solar mirror materials [7].

The procurement of heliostats, dispersed concentrating collectors, and other components of solar thermal electric power systems is supported by design specifications developed by federally funded laboratory research and development. Until the designs of the various system components are more stable, these specifications serve the function of standards for the program and the industry [8].

Programs have been initiated by DOE to develop draft standards for dispersed solar collectors, which appear to be the closest to widespread commercialization. the Thermal conversion Branch at SERI has started the construction of a test facility that will be used in developing thermal performance standards for concentrating collectors that produce temperatures in the $212^{\circ} \mathrm{F}$ to $350^{\circ} \mathrm{F}$ range. SERI will be working with American National 
systems for promulgation of the proposed thermal performance standard [9]. Although concentrating collectors are used mainly in industrial process heat applications, developments made in this effort will contribute to setting standards in solar thermal electric power applications.

The Environmental and Resource Assessment Branch in DOE is assessing health, saf ety, and environmental effects with regard to standards and criteria development for central receiver solar thermal power systems. Federal, state, and local standards and regulations exist that apply to the construction and operation of solar thermal electric power systems. These regulations are generaly concerned with air and water emissions, solid waste disposal, toxic material handling, and occupational safety and health matters. Institutions that are expected to provide support for standards in these areas are DOE, National Institute of Environmental Health Sciences, the National Bureau of Standards (NBS), Underwriters Laboratories (UL), the American National Standards Institute (ANSI), and the Electric Power Research Institute (RPRI) [4].

The STEPS FY79 program plan outlines research projects addressing the inter-relationship between the system design, system effects, and the need for standards modification or development for health, safety, and environmental issues [7]. This work will contribute to defining operating parameters, material durability and reliability, and safety considerations for the STEPS systems. For example, engineering analysis of solar thermal system designs are expected to yield requisite data on the potential pathways for fluid release into working and residential areas. These data will be used in establishing health and safety standards and standards for equipment design and quality control. The data will also be used in determining the system's ability to meet existing standards in these areas.

The institutional framework for developing voluntary consensus standards appears to be evolving for solar thermal power systems. National laboratories are developing materials and system performance data required for reliability and durability standards evaluation by voluntary consensus standard organizations. Private engineering and construction firms are involved in the initial design and systems development. Utilities are integrating solar thermal electric power systems into the traditional power supply networks. In addition, the voluntary consensus standards set by ASTM and ASME are being used as the baseline criteria for system evolution.

The early involvement of all participants in the development of standards for solar thermal electric power systems is the preferred path in standards development. Government involvement may remain minimal if such participation continues and expands to include more of the industrial sector. This objective may be attained through the award of research, development, and demonstration projects to firms having the potential for continued commercialization of the technology delivery system for solar thermal electric power system applications.

\section{BULDNG CODE STATUS}

Building codes do not explicitly prohibit or address the application of solar thermal electric power systems. Existing building code regulations for safety measures, load bearing members, electrical connections, plumbing, etc., apply to STEPS applications. A builder may have to pay extra attention to engineering and mechanical calculations to ensure that normal industry-approved construction practices are being followed. Potentially, building codes may need to be modified to address such issues as: 
- glare from collectors (safety),

- potential working fluid temperature hazards (safety), and

- electrical connections.

The Solar Thermal Power Systems program office has proposed a project to determine possible building code and zoning regulation modifications for solar total energy system deployment (Phase I) and to develop a methodology to assist local officials in making such modifications (Phase II). The two phases are projected for completion in 1981 and 1986 [4].

Most inconsistencies in building code occur in each community's regulation of residential and commercial construction. Most projected applications of central and dispersed STEP systems will not affect residential and commercial construction; thus major revisions to local building codes for STEP systems are not anticipated. Any building code modifications are expected to occur primarily in the adoption of revised national standards for solar thermal electric power systems. 


\section{REFERENCES}

1. SERI, Economic Feasibility and Market Readiness of Eight Solar TechnologiesInternal Draft Report (June 1978).

2. SERI, Annual Review of Solar Energy, Draft (June 1978).

3. Solar Technology Today-Special Report, Electric Power Research Institute Journal (March 1978).

4. DOE, Environmental and Resource Assessment Branch. Solar Program Assessment: Environmental Factors, Washington, D.C. (March 1977).

5. DOE, Environmental Development Plan (EDP)-Solar Thermal Power Systems (March 1978).

6. Waksman, D.; Pieker, J.H.; Dikkers, R.D.; and Streed, E.R.; "Plan for the Development and Implementation of Standards for Solar Heating and Cooling Applications," Center for Building Technology, National Bureau of Standards, Report NBSIR 76-1143 (August 1976).

7. DOE, Solar Thermal Power Systems Program-Program Summary (January 1978).

8. Communication with Barry Butler, Materials Branch Chief, SERI (July 1978).

9. Communication with James Castle, Thermal Conversion Branch, SERI (August 1978). 


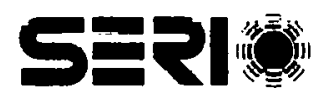




\section{APPENDIX H \\ OCEAN THERMAL ENERGY CONVERSION}

\section{HISTORY}

Ocean Thermal Energy Conversion (OTEC) is a means of capturing the sun's energy absorbed by the waters of the ocean. As early as 1881, Jacque D'Arsonval, a French physicist, proposed the concept of producing energy by using the ocean's temperature difference between warm surface water and cool deep water. In the early 1930 s Georges Claude, a French engineer, built a shore-based open-cycle power plant in Cuba that produced $22 \mathrm{~kW}$ of electricity. Economic and technical problems curtailed his effort. The ocean thermal concept was revised in 1965 by Anderson and Anderson. Since 1965, several conceptual configurations of OTEC plants have been developed by university researchers, aerospace companies, and shipbuilders [1].

\section{PRINCIPLE OF OPERATION}

The basic DOE design is a closed Rankine system in which warm surface water is used to vaporize a low boiling point working fluid, usually ammonia, in an evaporator. The vapor is expanded into a turbine that operates a generator to produce electricity. The working fluid is then condensed by cool deep water and returned to the working cycle. A temperature difference of at least $34^{\circ}$ to $40^{\circ} \mathrm{F}$ is required to operate the low-pressure turbines, necessitating the location of plants in semitropical or tropical waters.

An alternative concept is the open Rankine system which operates in much the same way except that seawater is the working fluid. This concept eliminates the need for heat exchangers, but it requires very large vacuum chambers.

OTEC plants may be land-based, moored (anchored via a cable to the ocean floor), or dynamically positioned by means of thrusters to counter the wind and ocean current forces [1].

\section{PEDERAL OTEC PROGRAM}

In 1972 the NSF and Research Applied to National Needs (RANN) began funding OTEC research. ERDA assumed responsibility for the OTREC studies in 1975. The OTEC program was transferred to DOE in October 1977. Funding for the program has grown from $\$ 85,000$ under NSF [2] to $\$ 13.5$ million in FY77. The DOE FY78 budget is $\$ 35$ million.

The federal OTEC program has focused on the near term island market with intermediate size $(10-100 \mathrm{MW})$ plants. The intermediate objective is the $10 \mathrm{MW}$ modular experiment [3].

The OTEC program is in the applied research phase of technology commercialization. Principal program elements and support offices are:

- program development,

- definition and systems planning, 
- engineering development,

- engineering test and evaluation,

- demonstration, and

- advanced research and technology development.

Primary issues in meeting the program's objectives have been identified and assigned to support offices. Most of the participants are government laboratories and their support contractors.

The definition and systems planning program is addressing issues relating to the future development of standards of OTEC systems. The establishment of O'TEC testing, safety, quality assurance, reliability, and siting research activities are the responsibility of this program element. 'I'he impacts of current and advanced technology, legal, political, institutional, and environmental factors are also being addressed. These and other studies will contribute to system and subsystem design and to environmental and performance definitions needed to establish standards for OTEC plants.

\section{TECHNOLOGY RESEARCH STATUS}

OTEC is completely in the applied research phase of the technology commercialization process. There are no working OTEC plants or pilot models; OTEC systems are conceptual designs only. Except for Claude's plant built in the 1930s, no plants have been constructed.

The component systems used in OTEC designs are not new. However, they of ten represent scaled-up, state-of-the-art equipment. No scientific breakthroughs are needed before OTEC plants can be constructed. Rather, the reliability of OTEC components in the ocean environment has to be proven technically and economically [4].

There are three conceptual OTEC designs: (1) closed-cycle system, (2) open-cycle systems, and (3) lift/foam-cycle systems. The closed cycle system is in the proposal development stage. The open-cycle system designed by George Claude was the earliest demonstration of the OTEC principle of operation. Initial lab feasibility studies have been completed, and an engineering design program has been started to determine the required size of the quipment.

The OTEC lift/foam cycle is a subset of the open cycle concept. Water is taken into the system and lifted in a vapor or foam stream created by a detergent or the natural foaming action of sea water. The liquid in the vapor stream, or in the foam, is lifted to a height sufficient to drive a hydraulic turbine. This approach is in the applied research phase with work concentrating on developing research plans for early feasibility studies. At this time this system is not considered a viable alternative to the closed or open cyle systems [4].

\section{STATUS OF STANDARDS FOR OTEC SYSTEMS}

As there are no operating OTEC systems, there are no voluntary consensus or government standards. 
Due to an OTEC plant's function and size, which is comparable to a nuclear power plant, it is projected that a standards and specification framework similar to that for nuclear power plants may evolve rather than a voluntary consensus standards system. Congressional mandate 10 C.F.R. 50, Appendices A and B, provides design, performance, and quality control criteria with references to existing material and product standards and specifications. In addition, a single agency, the Nuclear Regulatory Commission, regulates and directs nuclear power plant construction and operation. A similar management approach may be appropriate for OTEC plants. Numerous federal agencies with overlapping authorities could exert jurisdiction over OTEC plant construction and operation. Concern has been expressed $[5,6]$ that the multitude of regulatory, licensing, and permit requirements may impede OTEC commericalization. One agency to coordinate these activities would facilitate the process.

Candidate heat exchanger designs are being produced and tested in laboratory and coretest $(1 \mathrm{MW}$ ) units OTEC hardwork, including a cold water pipe, will be ocean tested at 1 $\mathrm{MW}_{\mathrm{e}}$ scale in the OTEC-1 component testing starting in 1980. Modular experiments (10 $\left.M W_{e}^{e}\right)$ are being planned to:

- demonstrate operational feasibility,

- provide test data to reduce costs, and

- support the establishment of an industry infrastructure.

The industry skills required for OTEC plant development and construction include shipbuilding and large-scale heat exchanger design and manufacture. To date two shipbuilders, several offshore well drilling companies, and several heat exchanger manufacturers are involved in the DOE OTEC R\&D program.

Interest in participating in the development of OTEC power plants has been expressed by several electric utilities: Florida Power and Light, Florida Power, Southern Companies, Middle South Services, and the Puerto Rican Water Resources Authority [7]. The involvement of these organizations is critical not only to the success of the OTEC technology development programs, but also to the evolution of standards and operating procedures.

OTEC technology is not expected to contribute significantly to the energy needs of this country before the 21 st century [8], primarily because of issues of technical and economic viability. Resolution of these issues alone will not ensure the future use of OTEC plants. Numerous standards issues must also be addressed, including those for testing methods, performance, reliability and durability, and environmental protection, health, and safety.

Numerous existing environmental protection, health, and safety standards and regulations are potentially applicable to OTEC plant construction and operation, although the extent to which they apply has not been determined. The FY79 OTEC program plan has programs to perform the initial review and assessment of these issues and to examine existing standards and regulations.

One of the regulatory requirements underlining the necessity for regulatory review and assessment is the Environmental Impact Assessment and Environmental Impact Statement (EIS) requirements in the National Environmental Protection Act (NEPA). NEPA requires that federal agencies prepare environmental impact statements for research and development programs and for each proposed demonstration plant. Hence, compliance with existing regulatory requirements must be confirmed in the EIA/EIS for each OTEC 
demonstration plant project. Further, each commercial OTEC facility will probably require an environmental impact assessment [6].

In addition to the federal regulatory requirements that may affect OTEC commercialization, state regulations could also apply. These include coastal zone management plans and procedures and state NEPAs. The latter could present barriers to OTEC plant siting because state environmental actions tend to be more stringent than federal Requirements [9].

\section{BUII.DNG CODE STATUS}

It is anticipated that state or local building code provisions will not apply to OTEC plant construction and operation. OTEC plants will generally be sited outside of local and state building code jurisdictions. Further, federal regulations for health and safety, the environment, and state and coastal zone managment plans will generally apply. Finally, only a few demonstration OTEC plants are expected to be constructed in the next 50 to 75 years. Long range planning to address alternate means to deal with the requirements nor mally handled by building codes would be appropriate in the near term, 


\section{REFERENCE}

1. SERI, Economic Feasibility and Market Readiness of Eight Solar TechnologiesInterim Draft Report (June 1978).

2. Panel on Ocean Ther mal Energy Conservation, Marine Board, Assembly of Engineering, Selected Issues of the Ocean Thermal Energy Conversion Program, National Academy of Sciences, Washington, D.C. (19_).

3. DOE, Ocean Thermal Energy Conversion (OTEC) Program-Program Summary (January 1978).

4. SERI, Annual Review of Solar Energy-Draft (June 1978).

5. Office of Technology Assessment, Renewable Ocean Energy Sources, Pat I-OTEC (May 1978).

6. Knight, Gary H.; Nyhart, J.D.; and Stein, Robert E.; Ocean Thermal Energy Conversion-Legal, Political, and Institutional Aspect, American Society of International Law, Lexing ton Books, Lexing ton, Mass. (1977).

7. DOE, Solar Energy-A Status Report (June 1978).

8. ERDA, Division of Solar Energy, Proceedings of the Third Workshop on Ocean Ther mal energy Conversion, May 8-10, 1975 (August 1975).

9. DOE, Environmental Development Plant (EDP)_OTEC 1977 (March 1978). 


\section{S\#Pl}




\begin{abstract}
APPENDIX I
OMB CIRCULAR ON

FEDERAL INTERACTION WITH THE VOLUNTARY CONSENSUS SYSTEM
\end{abstract}


TR-095

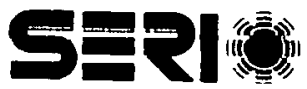


TEXT OF OMB CIRCULAR

\author{
EXECUTIVE OFFICE OF THE PRESIDENT \\ OFFICE OP MANAGEMENT AND BUDGET \\ WASHINGTON, D.C. 20503
}

TO THE HEADS OF EXECUTIVE DEPARTMENT AND ESTABLISHMENTS

SUBJECT: Interaction with Voluntary Consensus Standards-Developing Bodies

\title{
1. PURPOSE
}

This Circular establishes policy to be followed by executive branch agencies in working with voluntary consensus standards developing bodies to develop standards for materials, products, systems, services, processes, and practices. It also established policy to be followed by executive branch agencies in adopting and using such standards.

\section{BACKGROUND}

The Federal Government purchases many products and services, and regulates many products and activities which affect health, safety, and the national economy. To aid in ensuring that these functions are effectively and responsibly discharged, the Federal Government must depend upon reliable standards for products, processes, and services. Many standards, appropriate or adaptable for these purposes, are developed and are available from certain private and public organizations, known as voluntary consensus standards developing bodies. Federal participation in the voluntary standards-developing process will provide incentives and opportunities to establish standards that serve the total public need. In addition, Federal use of voluntary consensus standards, whenever practicable and appropriate, will reduce the cost of developing and using regulatory, as well as procurement, standards and will, thereby, serve the public interest. Adoption of such standards, moreover, is consistent with, and in furtherance of, the Federal Government's general policy of using commercial products, whenever feasible, and of relying on the private enterprise system to supply Government needs for goods and services, are enunciated in OMB Circular A-76.

\section{COVERAGE}

$$
\text { ; }
$$

This Circular applies to all executive agency involvement in voluntary consensus standardization activities, both domestic an international, but does not apply to United States participation in international standardization activities pursuant to treaties.

\section{DEFINITIONS}

$\Lambda s$ used in this Circular:

a. Executive agency (hereinafter referred to as agency) means an executive department, a military department, a military department, and an independent 
establishment within the meaning of sections 101,102 , and 104 [1] of Title 5, United States Code, and also a wholly owned Government corporation within the meaning of section 101 of the Government Corporation Control Act [31 U.S.C. 846].

b. Consensus, in the voluntary standards-development process, means substantial agreement, after a concerted effort to resolve objections. Agreement is reached by concerned interests according to the published procedures of a voluntary standards-development body and the judgment of official(s) duly appointed by a voluntary standards-developing body. Consensus implies more than the concept of a simple majority but not necessarily unanimity.

c. Voluntary consensus standard means a prescribed set of rules, conditions or requirements established by voluntary consensus standards-developing bodies, as defined in $4 \mathrm{e}$, concerning definition of terms; classificetion of components; specification of materials, performance, design, or operation; delineation of procedures; or measurement of quantity and quality in describing materials, products, systems, services, or practices. The term does not include professional standards of personal conduct or the private standards of individual firms.

d. Voluntary consensus standardization and standards-developing activities are the processes by which the rules, conditions, and requirements of voluntary consensus standards are developed.

e. Voluntary consensus standards-developing bodies are broadly-based, multimember, domestic and international groups, including nonprofit organizations, industry associations, and professional technical societies, which utilize the consensus method in the development of standards. These groups operate outside of the Federal Government and its agencies except that the Department of Commerce, under its procedures for the DevelujnIten! of Voluntury Product Standarde [15 CF $\bar{R} \vec{P}$ art 10$]$, is regarded as a voluntury consensus standards-developing body for purposes of this circular.

f. Cooperative testing means testing by interested parties to establish such things as accuracy, reproducibility, and reliability of standard test methods.

g. Secretary means the Secretary of Commerce.

1. Standards-Dévèloping Committees are committees, subcommittees, working groups, or any subdivision thereof established by voluntary consensus standards-developing bodies for the purpose of developing, revising, or reviewing standards and which are bound by the procedures of those bodies.

\section{POLICY}

It is the policy of the Federal Government, in both its procurement and regulatory roles, to:

a. Rely on voluntary consensus standards, both domestic and international, whenever feasible and consistent with law and regulation pursuant to law; 
b. Participate in voluntary consensus standards-developing activities when such participating is in the public interest and is compatible with agencies' missions, authorities, priorities, and budget limitations;

c. Coordinate agency participation in voluntary consensus standards-developing activities so that (1) the most effective use is made of participating Federal agency representatives and (2) the views expressed by such personnel are in the public interest and, as a minimum, do not conflict with the interests and views of Federal agencies.

\section{POLICY GUIDELINES}

In implementing the policy established by this Circular, agencies should recognize the positive contribution of standardization and related activities, such as product and compliance testing and certification. It also must be recognized, however, that these activities, if improperly conducted, could suppress free and fair competition, impede innovation and technical progress, exclude safer and less expensive products, or otherwise adversely affect trade, commerce, health, or safety. Full account shall be taken of the impact on the economy, applicable Federal laws, policies, and national objectives including for example, laws and regulations relating to antitrust, national security, small business, product safety, environment, and conflicts of interest. In light of these considerations, the following policy guidelines are established to assist and govern implementation of the policy enunciated in paragraph 5, except that the provisions of paragraph $6 \mathrm{c}$ are not applicable to Federal particiapation in international organizations' which develop and issue voluntary international standards.

\section{a. Reliance on Voluntary Standards}

(1) Voluntary consensus standards will be adopted, in whole or in part, and will be used by Federal agencies in lieu of developing and using in-house standards when voluntary consensus standards will serve the agencies' purposes and are consistent with applicable laws and regulations;

(2) Voluntary consensus standards will be assigned preference in procurement actions in the absence of mandatory Federal standards unless use of such voluntary consensus standards would result in impaired functional performance, unnecessary overall cost to the Government or the Nation, anticompetitive effects, or other significant disadvantages;

(3) Voluntary consensus standards will be utilized in Federal regulatory applications after a careful evaluation of such standards assures their adoption and use to be in full accordance with the agencies' statutory missions and resporisibilities, and other applicable laws and regulations;

(4) Voluntary consensus standards which are adopted by Federal agencies will be cited, along with the dates of their issuance and source of availability, in appropriate publications, regulatory orders, and related in-house documents;

(5) Notwithstanding the foregoing, agencies will not be inhibited, if within their statutory authorities, from developing and using in-house standards in the event that voluntary standards-developing organizations cannot or do not 
develop a standard needed by, and acceptable to, these agencies or do not do so in a timely fashion. Nor shall the policies contained in this Circular be construed to commit any agency to the use of a voluntary standard which, in its opinion, is inadequate, does not meet statutory criteria, or is otherwise inappropriate for the agency concerned.

\section{b. Participation in Voluntary Consensus Standands-Developing Bodies}

(1) Participation by Federal representatives shall be authorized by appropriate agency officials but such participation, of itself, shall not connote agency agreement with, or endorsement of, decisions reached by voluntary standardsdeveloping committees or of standards approved and published by voluntary consensus standards-developing bodies.

(2) For regulatory applications, participation by Federal agency representatives should be aimed at contributing to the development of voluntary standards which will minimize the need for development of mandatory Federal standards, or as a minimum, collecting technical and other information which will provide a basis for well-considered Federal regulatory actions.

(3) For procurement applications in which Federal requirements are consistent with those of the private sector, participation by Federal agency representatives should be aimed, principally, at contributing to the development of voluntary consensus standards which will eliminate the necessity for in-house development of Federal procurement standards.

(4) The form of participation by Federal agency representatives may extend to voting in standards-developing and standards approving committees, if authorized by the head of the department or agency.

(5) Federal agency participants in voluntary consensus standards=developing committees will avoid dominating or exerting undue influence in such cummiltees. The number of Individual federal agency participants on a given voluntary standards-developing committee shall be kept to the minimum required for effective presentation of the various program, technical, and other concerns of Federal agencies.

(6) The granting of Federal support to a voluntary consensus standards-developing committee shall be limited to that which is clearly in furtherance of an agency's missions and responsibilities. The amount of Federal support given shall be no greater than that of all non-Federal participants in that committee. The form of agency support may extend to:

(a) Direct financial support; e.g., grants, sustaining memberships, and contracts;

(b) Administrative support; e.g., travel cost, hosting of meetings, and secretarial functions;

(c) Technical support; e.g., cooperative testing for standards evaluation, and participation of agency personnel on standards committee activities; and 
(d) Joint planning with the voluntary standards-developing sector to ensure a coordinated effort in resolving priority standardization problems.

(7) Participation by agencies should not extend to decisionmaking involvement in the policy making process of voluntary standards-developing bodies on issues relative to the internal managment of such bodies (e.g., election of officers, setting of membership fees), except in accordance with the policies and procedures established by the Secretary of Commerce.

\section{c. Identification of Voluntary Consensus Standards-Developing Bodies for Federal Participation}

As a necessary precondition to Federal participation in voluntary consensus standardsdeveloping bodies, such bodies must be identified and listed by the secretary of Commerce as conducting their standards-development activities in accordance with the following due process and other basic criteria:

(1) That adequate public notification of meetings and other standards-development activities is provided;

(2) That standards-development meetings are open to interested persons and that unreasonable restrictions on membership on standards-development committees by means of professional or technical qualifications, trade requirements, unreasonalbe fees, or other such restrictions are avoided:

(3) That standards-developing bodies make a good faith effort to achieve appropriately balanced representation of all affected interests on their standards-developing committees. Such representation may include, for example, consumers; small business concerns; manufacturers, labor; suppliers; distributors; industrial, institutional and other users; environmental and conservation groups; and state and local procurement and code officials;

(4) That prompt and full consideration is given to the expressed views and interests of all interested persons;

(5) That adequate and impartial appeals mechanisms are in force for use by interested parties;

(6) That appropriate and complete records are maintained of formal discussions, decisions, standards drafts, technical or other rationale for critical requirements of standards, meeting minutes and balloting results; and that such records are readily accessible to all interested persons on a timely basis;

(7) That literature published by standards-developing bodies specifically state that participation by Government officials in that organization does not constitute Government endorsement of that organization or the standards which it develops;

(8) That standards-developing bodies publish their operating procedures and make them avallable to all interested parties.

(9) The standards-developing bodies agree to utilize the Department of Commerce mediation and conciliation service, as described in paragraph 7a [6], in the 
resolution of procedural complaints by private sector parties, and to be bound by the results of that process, provided that appeals procedures of the voluntary consensus standards-developing bodies have been exhausted.

(10) That existing standards are periodically reviewed and revised, as necessary, and that access to the review process is granted to all interested persons;

(11) That preference is given to the use of performance criteria in standards development when such criteria may be used in lieu of design, materials, or construction criteria.

\section{RESPONSIBILITIES}

a. The Secretary of Commerce will:

(1) Direct, coordinate, and oversee executive branch implementaion of the policy in pargraph 5 , in accordance with the policy guidelines in paragraph 6. The secretary will establish within six months of the date of this Circular. (a) an interageney Committee on Standards Policy which the Secretary may call upon when needed to assist in implementing the policy contained herein and (b) written procedures to implement the provisions of this Circular. All executive branch agencies concerned with standardization activities will be represented on that Committee and will cooperate with the Secretary, as requested, in carrying out tasks assigned to the Committee.

(2) Develop and maintain current a list of voluntary consensus standardsdeveloping organizations which certify to the Secretary that they are in compliance with the due process and other basic eriteria cited in paragraph $6 \mathrm{c}$, and which provide published evidence of such compliance. The Secretary will take prompt action on such applications and may take appropriate steps to determine whether such organizations are in fact conducting their activities in accordance with the aforecited due process and other basic criteria. The secretary may call upon the Department of Justice and the Federal Trade Commissions for assistance in establishing speclflc provisions for the due process and other basic criteria in paragraph 6c, and in evaluating adherence by voluntary standardsdeveloping bodies to those provisions.

(3) Establish procedures by which the listing of a voluntary standardsdeveloping body can be challenged by interested persons. To this end, the Secretary will establish procedures by which (a) such bodies can be removed from the list if a determination is made by the Secretary that they are operating and after appropriate notice continue to so operate, without benefit of the due process and other basic criteria cited in paragraph 6c, above, (b) Federal agencies will be notified of such removal for the purpose of ceasing their participation in such bodies, and (c) public notice will be provided of actions taken.

(4) Establish and maintain current, with the cooperation of Federal agencies, a central register of all voluntary standards-developing activities in which Federal agencies participate. 
(5) Establish and maintain current, a consolidated listing, cross-referenced by subject, of standards developed by voluntary consensus standardsdeveloping bodies and by Federal agencies. Such listing of standards developed by bodies other than Federal agencies shall not necessarily constitue Government endorsement thereof.

(6) Establish a program which shall make available a Department-sponsored meditation and conciliation service for the rapid resolution of procedural complaints by private sector parties against voluntary consensus standards-developing organizations. As a precondition to invoking that service, a complainant must seek relief from, and have exhausted all available sources of remedy within the affected voluntary standardsdeveloping organizations. Such a service shall have, as one of its requirements, the consent of complainant and respondent to be bound by the results of that process.

(7) Report annually to the Office of Management and Budget concerning agency implementation of this Circular.

b. The heads of executive agencies concerned with standards and standardization activities will:

(1) Implement the policy in paragraph 5 of this Circular in accordance with the policy guidelines in paragraph 6 and the procedures to be established by the Secretary of Commerce, within 120 days of the issuance of those procedures.

(2) Establish appropriate procedures to ensure that:

(a) Agency representative refrain from participating in voluntary consensus standards-developing bodies which are not listed by the Secretary of Commerce as conducting themselves in accordance with the due process and other basic criteria cited in paragraph 6c;

(b) Agency representatives to voluntary consensus standards-developing bodies are familiar with the due process and other basic criteria contained in paragraph $6 \mathrm{c}$, and that agency representaives who learn of an apparent infringement of the aforecited criteria by a listed voluntary consensus standards-developing body register their questions and concerns with that body and with their agencies;

(c) The Secretary of Commerce is notified of such incidents of apparent noncompliance with the aforecited due process and other basic criteria by a listed voluntary consensus standards-developing body.

(3) Establish appropriate procedures by which agency representatives participating in voluntary consensus standards-developing organiations will, to the extend possible, ascertain the views of the agency on matters of paramount interest and will, as a minimum, express views which are not inconsistent or in conflict with agency views. 
(4) Endeavor, when two or more agencies participate in a given voluntary standards-developing organization, to coordinate the views of their respective agencies on matters of paramount importance so as to present a single, unifield position reflective of the public interest. In instances where agreement is not reached by the affected agencies, a lead agency will be designated by the Secretary of Commerce and will be responsible for developing a unified position on the important matter at issue. In so doing, that designated lead agency will consider carefully the views of the other participating Federal agencies.

(5) Participate in the Interagency Committee on Standards Policy to be established by the Secretary of Commerce and will cooperate with the Secretary, as requested, in carrying out the assignments of that committee.

(6) Consult with the Secretary of Commerce in the development and issuance of agency regulations implementing this Circular, and report annually to the Secretary on the status of agency interaction with voluntary consensus standards-developing bodies.

\section{REPORTING REQUIREMENTS}

One year from the date of issuance of this Circular, and each year thereafter, the Secretary of Commerce will submit to the Office of Management and Budget a report on the status of Federal interaction with voluntary consensus standards-developing bodies. As a minimum, the report will include the following imformation:

a. Nature of extend of Federal agency participation in and support of voluntary consensus standards-developing bodies;

b. Use by Federal agencies of new or revised voluntary standards, and the sources of such standards, for procurement as well as for regulatory purposes;

c. A list of voluntary consensus standards-developing bodies which have been identified as complying with the due process and other basic criteria of this Circular - and of such bodies which have been removed or have not been considered eligible for inclusion on the list due to noncompliance with the aforecited due process and other basic criteria, and the nature of that noncompliance;

d. Summary of the nature of procedural complaints against voluntary consensus standards-devcloping bodies in accordance with the program to be developed, and a summary of the disposition of such complaints; and

e. Evaluation of the effectiveness of the policy promulgated in this circular and recommendations for change or modification, as appropriate.

\section{INQUIRIES}

For inforamtion concerning this Circular, contact the Office of Management and Budget, Office of Federal Procurement Policy, telephone 202-395-3336. 


\author{
APPENDIX J \\ EXTRACT FROM DOE/CABO CONTRACT EM-78-COT-4281 \\ "DEVELOPMENT OF A MODEL DOCUMENT FOR CODE OFFICIALS ON \\ SOLAR HEATING AND COOLING OF BUILDINGS" EXECUTED SEPTEMBER 1978
}

\author{
STATEMENT OF WORK
}

\title{
I. INTRODUCTION
}

This program is a major undertaking to accelerate the commercialization of solar heating and cooling of buildings by updating the building codes and standards that are enforced in every community. It will be conducted with, and through, state and local officials responsible for building code administration, as well as with representatives of the professions, industry, labor and consumers. The program will provide basic documents and a framework to guide state and local agencies, based upon the combined input and consensus of the different groups and interests affected by solar technologies. Widespread utilization of solar technologies will be greatly influenced by the requirements and acceptance procedures in the building codes and standards administered by the states and localities. Historically, lack of uniformity among the many thousands of different building codes has inhibited the introduction of technological innovations in building construction. The Federal Government is interested in minimizing the impact of such contraints on solar heating and cooling installations in buildings through the development of model code documents for adoption by states and localities and through training officials responsible for code administration.

In carrying out its mission to assist the development of a viable solar industry and to protect the public in the use of solar technologies, DOE has supported programs aimed at developing standards for solar heating and cooling applications in buildings. In accordance with Public Law 93-409, the "Solar Heating and Cooling Demonstration Act of 1974," interim performance criteria have been developed for residential and commercial buildings. These criteria are being utilized in Federal solar demonstration programs, as well as housing assisted under HUD's FHA mortgage insurance program.

With the development of these technical standards and performance criteria, it is now necessary to advance to the next phase in order to obtain uniform treatment of solar technologies in state and local building codes. The primary objectives of this contract are (1) to utilize institutional mechanism at various levels of government and in the private sector to develop a model code document in accordnce with consensus procedures and due process, and (2) to promote greater understanding and acceptance of solar technologies among code officials.

The existing system responsible for the preparation, development, dissemination, adoption and administration of standards and building codes is very complex, often involving federal, state and local units of government as well as national, regional, state and private sector organizations. Current policy directions undertaken by the Federal Government, as recently enunciated by the OMB in its Circular dated December 22, 1977, encourage support for this system, with special emphasis placed on expanding procedures in order to broaden participation by small business and consumer representatives. 


\section{SCOPE}

This contract will utilize major components of the existing code system that serve all levels of government and the bulding industry, so as to accelerate the development of a model document for solar heating and cooling of buildings. The model code will incorporate existing standards for solar systems that are now acceptable as determined by a broad consensus of all ma.jor interests. Participating in this effort will be representatives of code officials, professionals, industry, labor, consumers, and government agencies. Inasmuch as the prime objective of this phase of the work is to develop a model document that the states and localities could adopt, their interests will also be represented.

Figure 1 is a summary listing of the planned tasks for the overall program. Each part is discussed individually in the following sections.

\section{PART I - DEVELOP CODE AND IMPLEMENT THE CONSENSUS PROCESS}

\section{Task 1 - Organization of the Executive Committee of the Consensus Body}

The Executive Committee of the consensus body will be organized in accordance with the consensus institutional framework previously developed by CABO and NCSBCS under DOE Contracts $78-3630$ and 78-3629 respectively. This body will have the responsibility for final approval of the institutional framework for consensus, including:

- organization and make-up task forces;

- operating procedures to insure consensus;

- establishment and operation of appeals mechanism.

It is anticipated that a Secretary for the Executive Committee will be establisher. Consideration shall also be given to the establishment of a final appeals mechanism where the deciding body is a recognized organization operating outside of the codes and standards-making system.

Task 2 - Implementation of the Code Development Plan

Under the direction of the Executive Committee, the code development plan shall be implemented. Task forces shall be designated and organized in accordance with the approved plan and they shall proceed with the development of the document. The document development task forces will be responsible for developing the drafts of specific chapters of the model document for final review and integration by the Executive Committee, then reviewing comments and revising the drafts based upon consideration of comments.

\section{PART I Develop Document \& Implement the Consensus Process}

1. Organize Executive Committee

2. Implement the Plan

a. Designate and organize Task Forces and Subcommittees

b. Develop document 
3. Maintain concurrent reviews

a. Technical

b. Schedule

4. First draft document

5. Call for comments

6. Hold public forum

7. Revise document

8. Second draft

9. Consensus review and vote

10. Publish

11. Disseminate document

Part II Develop and implement Education \& Training Program

1. Organize training development team

2. Develop plans for the education and training program

3. Develop draft of training materials

4. Pilot programs

5. Revise and publish material

6. Instructor training

7. Deployment of courses

8. Monitor \& update

PART III Development and Implement Technology Review and Acceptance Procedures

1. Evaluate existing processes

2. Develop recommendations

3. Test the recommendations

4. Develop guidelines

Task 3 - Maintenance of Concurrent Reviews

As' the development of the draft document proceeds, provision shall be made for concurrent technical reviews of the output of the task forces. This shall be accomplihsed by having the individuals on the task forces submit to the organizations they represent technical working papers containing complete or partial sections of the drafts, allowing these organization 30 days to comment.

\section{Taks 4 - Publication of the First Draft of the Code}

The first draft of the document shall be published within six (6) months of the start of the contract. Upon completion of chapter drafts, the Executive Committe shall integrate the chapters and obtain concurrence for release from the technical task forces.

\section{Task 5 - Call for Comments}

The contractor shall distribute copies of the first draft document to a mailing list with a request for comments. That mailing list shall represent a broad cross-section of 
professionals, code officials, labor, consumers, and the states and localities, and shall be prepared under directions of the Executive Committee.

\section{Task 6 - Public Forum}

The contractor shall coordinate and provide, with due notice, a,public for um to allow the opportunity for interested groups and/or individuals to comment on the first draft of the document.

\section{Task 7 - Revision of the Document}

Based upon the comments received, both written and from the Public Forum, the various technical task forces shall revise the draf ts of individual chapters as required and submit them to the Executive Committee.

\section{Task 8 - Publication of the Second Draft of the Code}

The Executive Committee shall integrate the chapters of the technical task forces, obtain concurrence of the task forces and release the second draft for formal consensus review.

\section{Task 9 - Consensus Review and Vote}

In accordance with the approved consensus process, the second draft of the document shall then be submitted to the Executive Committee members for formal consensus review and voting. Any negative votes must be accompanied by a written justification and rationale.

\section{Task 10 - Publication of the model Document}

Upon reaching consensus, the Executive Committee shall arrange for publication of the first edition of the "Model Document of Solar Heating and Cooling of Buildings and Appurtenant structures."

\section{Task 11 - Distribution of the Model Document}

DOE shall print and the contractor shall distribute 10,000 copies of the document. In order to insure broad distribution to states and local officials responsible for adoption and implementation of building regulations, the project team, as one part of the distribution plan, shall work with the following seven national public interest groups:

- National Governors' Association

- Council of State Governments

- National Conference of State Legislatures

- National Association of Counties 
- National League of Cities

- U.S. Conference of Mayors

- International City Managers' Association

\section{PART I - DEVELOPING AND IMPLEUENT EDUCATION AND TRAINING PROGRAM}

The objective of this part of the program is to develop and test training materials, provide instructor training and assist states and communities in providing training to building regulatory personnel on the solar document. The curriculum shall be planned in a manner which will allow its integration into the course material developed for the "Code for Energy Conservation in New Building Construction" resulting in an additional module in a comprehensive energy course for energy conservation in buildings.

\section{Task 1 - Organization of the Training Development Team}

A training development task force shall be formed consisting of, but not limited to, representatives from the following organizations:

- National Conference of States on building Codes and Standards, Inc.

- National Academy of Code Administration

- Model Code Groups

- Selected Universities \& College

- Trade Associations

- Other groups as appropriate, such as AMCBO.

This team shall be responsible for the development, distribution, and implementation of appropriate programs of instruction and training materials.

\section{Task 2 - Development of the Plans for the Education and Training Program}

Working closely with the document development task forces, the team shall develop the plans for the education and training program, identifying the structural framework of the task force as well as the intended audiences and their needs.

\section{Task 3 - Development of the Draft Training Materials}

Based on guidelines, procedures, and scope of efforts outlined in the plan described above, the team shall commence with the development of appropriate course materials, instructor manuals, visual aids, notes, and other required instructional materials based on the "Model Document for Solar Heating and Cooling Applications" being developed.

\section{Task 4 - Pilot Programs}

Upon completion of the draft instructional materials described in Task 3, the contractor shall conduct six sessions to test and evaluate the prototype course materials. Each of 
the prototype sessions shall be closely monitored to ascertain the effectiveness of the materials. All comments and recommendations received from the participants shall be evaluated, analyzed, and where appropriate, incorporated into the final edition of the training materials.

\section{Task 5 - Revision and Publication of Material}

The contractor shall finalize and publish the instructional material.

\section{$\underline{\text { Task } 6}$ - Instructor Training}

The contractor shall conduct one or more national institutes, as well as a series of regional meetings as required, to develop a cadre of trained instructors drawn from among building code officials and other professions to conduct courses at the state and local levels.

\section{Task 7 - Deployment of Course}

The contractor shall develop procedures for the systematic deployment of the instructional courses including:

a. Methods of conducting courses:

- on-campus resident week-long sessions,

- programmed instruction correspondence courses,

- closed circuit 'I'V courses,

- traveling team weekly sessions,

- video cassette self-study courses;

b. integration in adult education, community colleges, and extension courses;

c. use of qualified instrue tors;

d. logistical support of courses;

e. certification procedures for successful participants;

f. monitoring procedures to assure quality control;

g. funding level requirements and options thereto.

The contractor shall also develop guidelines and programs to assist state and local jurisdictions in arranging for the conduct of the various courses.

\section{Task 8 - Monitoring Programs and Updating Material}

To ensure that effective deployment of courses is being carried on, CABO shall provide an ongoing program of assistance to states and communities. In addition, the education 
and training materials require periodic updating by $\mathrm{CABO}$ as standards and codes are revised.

\section{PART III - DEVELOP AND IMPLEMENT TECHNOI,OGY REVIEW AND ACCEP- TANCE PROCEDURES}

The objective of this part is to recommend new techniques and mechanisms for the review and acceptance of solar innovations and technology to assist code officials in evaluating new systems, with the intent of minimizing the number of reviews to which innovations must be subjected before gaining acceptance by the regulatory bodies.

\section{Task 1 - Evaluation of Existing Processes}

The contractor shall review and evaluate the current processes for acceptance of new solar technology to identify those areas in which improvements could be made to reduce time and costs while still maintaining the integrity of the evaluation system.

\section{Task 2 - Development of Recommendations}

The contractor shall develop recommendations for improvement of the acceptance process and gain concurrence from the participating organizations. Recommendations shall include consideration of a single integrated process as well as possible reciprocity between existing processes and organizations.

\section{Task 3 - Testing the New Process}

With the coopcration of the arganizations conducting the review procedures, the contractor shall develop and conduct the demonstration program for the new acceptance process. A one-year trial of the recommended procedures shall be followed by possible revisions to the system with appropriate actions to promote full acceptance by all organizutions.

\section{Task 4 - Acceptance system Guidelines}

With the concurrence of the model code organizations, the contractor shall develop and publish a set of guidelines containing an explanation of the system and specific procedures to ussist innovators to gain acceptance of new technologies. 


\begin{tabular}{|c|c|c|c|}
\hline $\begin{array}{c}\text { Document Control } \\
\text { Page }\end{array}$ & $\begin{array}{l}\text { 1. SERI Report No. } \\
\text { TR-53-095 }\end{array}$ & 2. NTIS Accession No. & 3. Recipient's Accession No. \\
\hline \multicolumn{3}{|l|}{ 4. Title and Subtitle } & 5. Publication Date \\
\hline & & & 6. \\
\hline \multicolumn{3}{|l|}{ 7. Author(s) } & 8. Performing Organization Rept. No. \\
\hline \multirow{2}{*}{\multicolumn{3}{|c|}{$\begin{array}{l}\text { 9. Performing Organization Name and Address } \\
\text { Solar Energy Research Institute } \\
1536 \text { Cole Boulevard } \\
\text { Golden, Colorado } 80401\end{array}$}} & $\begin{array}{l}\text { 10. Project/Task/Work Unit No. } \\
5311,6107-02\end{array}$ \\
\hline & & & $\begin{array}{l}\text { 11. Contract (C) or Grant (G) No. } \\
\text { (C) } \\
\text { (G) }\end{array}$ \\
\hline \multirow{2}{*}{\multicolumn{2}{|c|}{ 12. Sponsoring Organization Name and Address }} & \multirow[t]{2}{*}{ - } & $\begin{array}{l}\text { 13. Type of Report \& Period Covered } \\
\text { Technllcal Report }\end{array}$ \\
\hline & & & 14. \\
\hline
\end{tabular}

15. Supplementary Notes

16. Abstract (Limit: 200 words)

This report is a premier on solar standards development. It explains the development of standards, building code provisions, and certification programs and their relationship to the emerging solar technologies. These areas are important in the commercialization of solar technology because they lead to the attainment of two goals: the development of an industry infrastructure and consumer confidence. Standards activities in the four phases of the commercialization process (applied research, development, introduction, and diffusion) are discussed in relation to institutional issues. Federal policies have been in operation for a number of years to accelerate the development process for solar technology. These policies are discussed in light of the Office of Management and Budget (OMB) Circular (see Appendix I) on federal interaction with the voluntary consensus system, and in light of current activities of DOE, HUD, and other interested federal agencies. The appendices cover areas of specific interest to different audiences: activities on the state and local level; and standards, building codes, and certification programs for specific technologies. In addition, a contract for the development of a model solar document let by DOE to a model code consortium is excerpted in Appendix $\mathrm{J}$.

17. Document Analysis

a. Descriptors

D. Identifiers/Open-Ended Terms

c. UC Categories

$59,59 a, 59 b, 59 c, 60,61,62,62 a, 63$

18. Availability Statement

\begin{tabular}{|l|}
\hline $\begin{array}{l}\text { 19. No. of Pages } \\
139\end{array}$ \\
\hline 20. Price \\
$\$ 7.25$ \\
\hline
\end{tabular}

